Prepared by the USGS National Wildlife Health Center

\title{
Bat Rabies and \\ Other Lyssavirus Infections
}

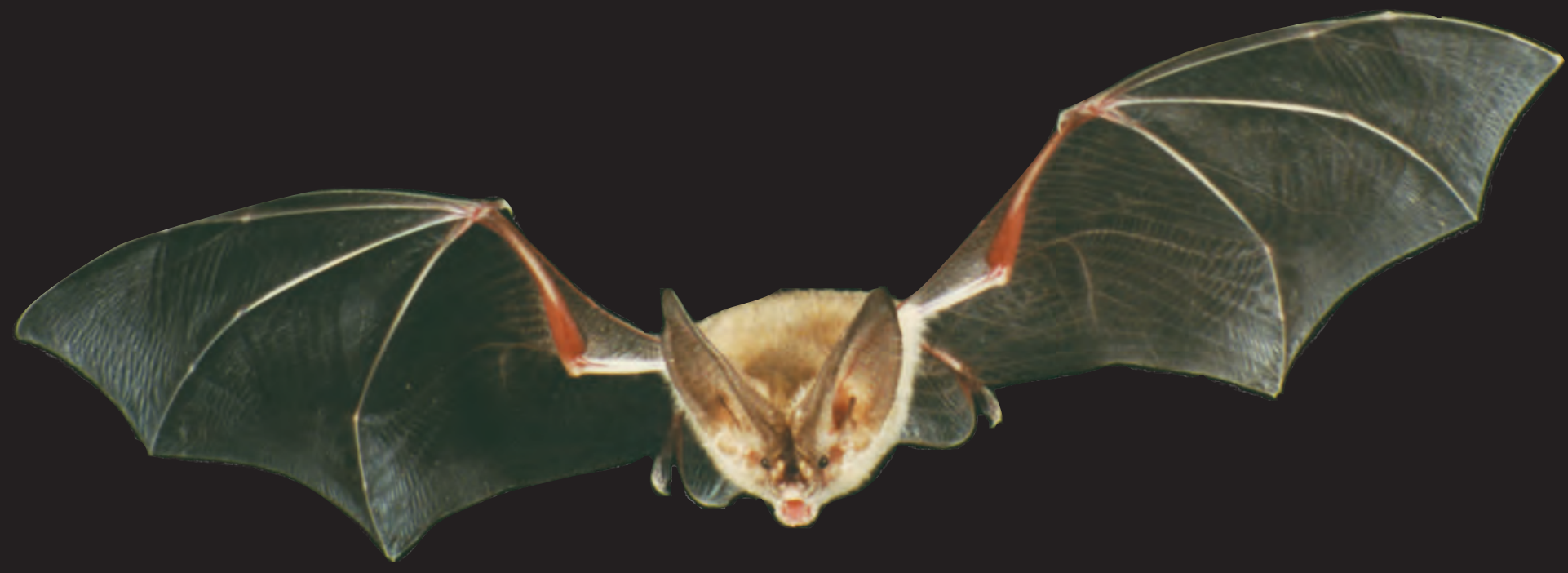

Circular 1329 
Front cover photo (D.G. Constantine)

A Townsend's big-eared bat. 


\section{Bat Rabies and Other Lyssavirus Infections}

By Denny G. Constantine

Edited by David S. Blehert

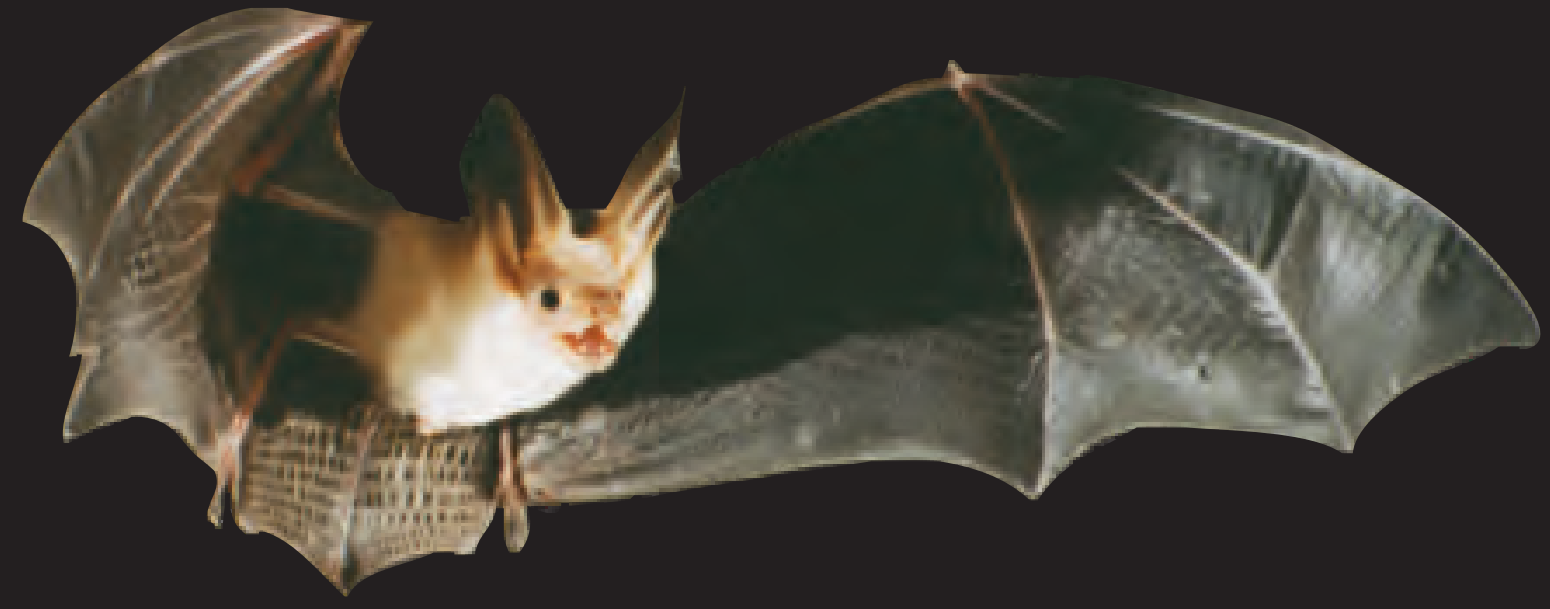

Circular 1329

U.S. Department of the Interior

U.S. Geological Survey 


\section{U.S. Department of the Interior \\ KEN SALAZAR, Secretary}

\section{U.S. Geological Survey Suzette M. Kimball, Acting Director}

U.S. Geological Survey, Reston, Virginia: 2009

For more information on the USGS - the Federal source for science about the Earth, its natural and living resources, natural hazards, and the environment, visit http://www.usgs.gov or call 1-888-ASK-USGS

For an overview of USGS information products, including maps, imagery, and publications, visit http://www.usgs.gov/pubprod

To order this and other USGS information products, visit http://store.usgs.gov

Any use of trade, product, or firm names is for descriptive purposes only and does not imply endorsement by the U.S. Government.

Although this report is in the public domain, permission must be secured from the individual copyright owners to reproduce any copyrighted materials contained within this report.

Suggested citation:

Constantine, D.G., 2009, Bat rabies and other lyssavirus infections: Reston, Va., U.S. Geological Survey Circular 1329, $68 \mathrm{p}$.

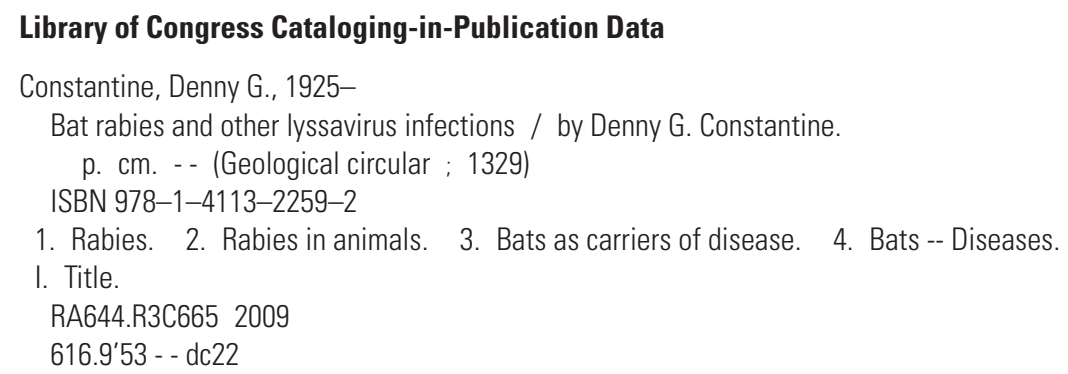




\section{Related USGS Publications}

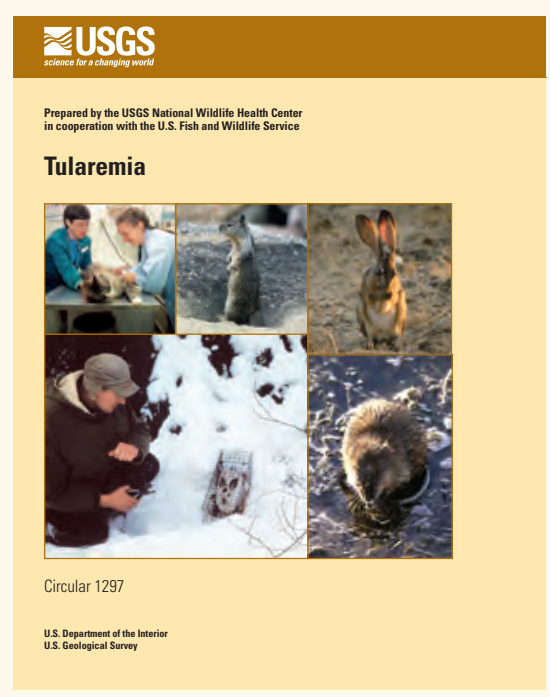

Tularemia, by Milton Friend, USGS Circular 1297 (also available on CD-ROM)
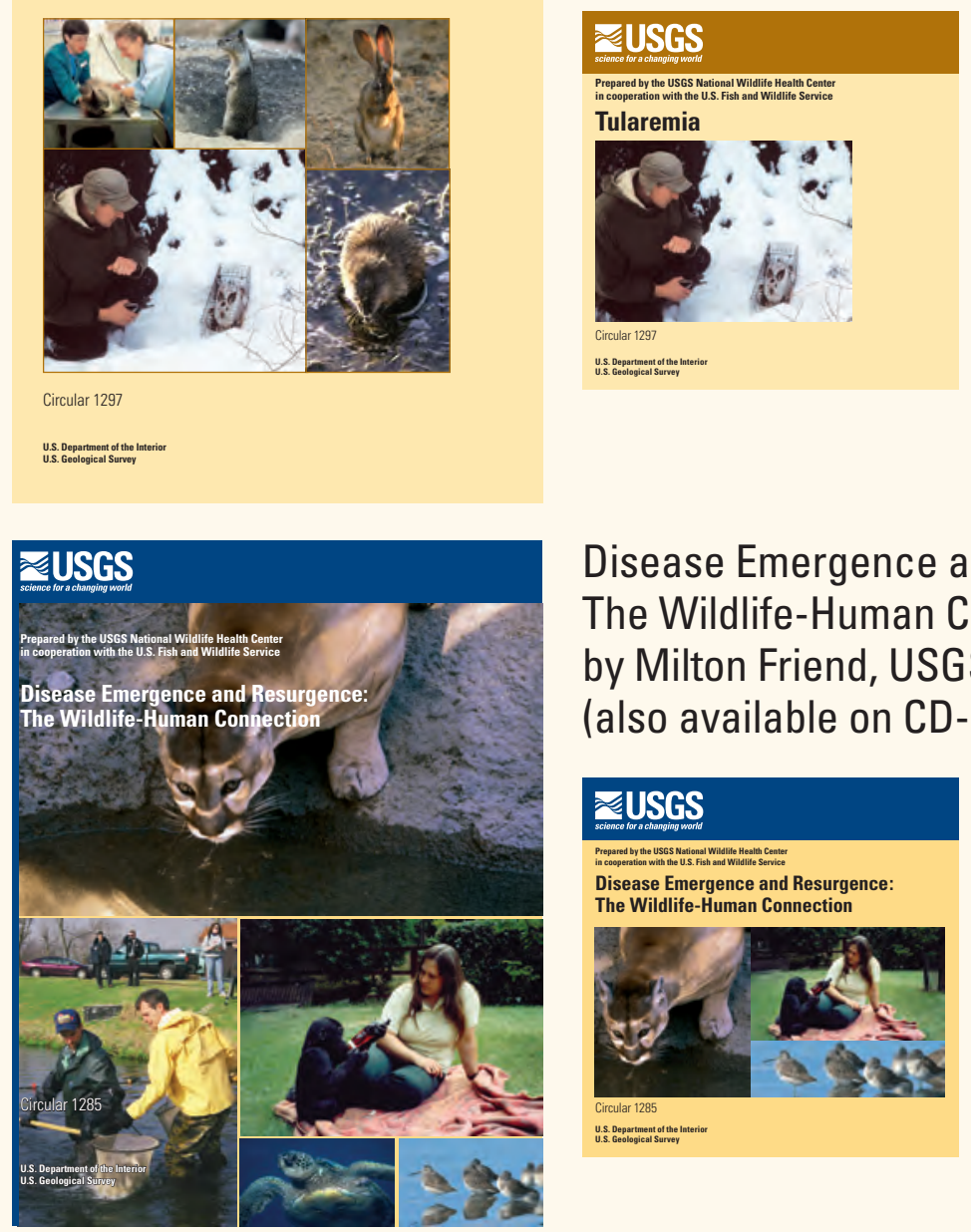

Disease Emergence and ResurgenceThe Wildlife-Human Connection, by Milton Friend, USGS Circular 1285 (also available on CD-ROM)

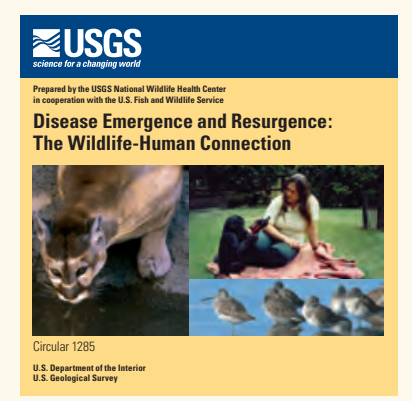

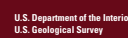

Field Manual of

Wildilife Diseases

Field Manual of Wildlife DiseasesGeneral Field Procedures and Diseases of Birds, edited by Milton Friend and J. Christian Franson, USGS Information and Technology Report 1999-001

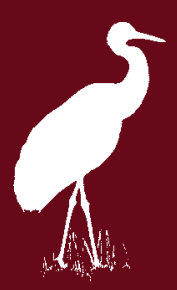

\section{ZUSES}





\section{Foreword}

In many ways, bats are the nocturnal equivalent of birds (Kunz, 1982). Like birds, they consume large numbers of insects that cause harm to agriculture and to humans; researchers estimate that the value of bat control of cotton crop pests in eight counties in south-central Texas ranges from $\$ 121,000$ to $\$ 1,725,000$ per year (Cleveland and others, 2006). Bats also play an important role as pollinators and in spreading plant seeds by eating the fruits of some plants. The estimated 1,100 species of bats worldwide comprise about 20 percent of all mammal species (Tudge, 2000), are second only to rodents in number of species, and are likely the most numerous in total individuals of any type of mammal (Kunz 1982). Despite their important ecological roles and benefits to humans, bats are among the most maligned and mysterious animal group in existence, largely due to folklore and unfamiliarity with the true nature of these primarily nonhematophagous, or nonblood feeding, species (King, 1993).

The notoriety associated with rabies in vampire bats of the tropical and subtropical regions of the New World is unfortunately transposed by many to also reflect the demeanor and consequences of the presence of other types of bats. Clearly, vampire bat rabies was a prominent challenge for early Spanish colonists and their domestic animals during their settlement within Latin America (Baer, 1975a; Lopez and others, 1992). Because of vampire bat rabies, the presence of bats in urban environments of the Northern Hemisphere commonly elicits fear among many adults, but wonderment among the young and the young-at-heart. The former tend to associate the presence of bats with rabies, while the latter see only the uniqueness of these highly specialized flying mammals and often place themselves at risk by attempting to capture and handle these animals for closer examination.

Rabies in a nonhematophagous North American bat was not documented until 1953, when a yellow bat (Dasypterus floridanus, now Lasiurus intermedius, the Northern yellow bat) was examined following its aggressive biting of a 7-year-old boy in Florida. Fortunately, despite no previous documentation of rabies in insectivorous bats in the United States, the child received prompt postexposure prophylactic treatment for rabies and did not become clinically ill (Venters and others, 1954, Scatterday, 1954). Subsequent investigations resulted in retrospective diagnoses of bat rabies in the USA in 1951 and, possibly, even 30 years earlier, suggesting the presence of rabies in insectivorous bats long before its recognition (Baer, 1975b). During recent decades, an average of 700 to 800 cases of rabid insectivorous bats has been diagnosed annually in the USA (Rupprecht and others, 1995). During 2006, 1,692 cases of rabies were reported in bats, a 14.5 percent increase over 2005 and 24.4 percent of the total animal rabies cases. Only raccoons accounted for a greater number of rabies cases in the USA during 2006 (Blanton and others, 2007).

Although the annual number of human rabies deaths in the USA remains very small, most of those deaths are attributed to unrecognized exposures to rabies associated with bats, primarily the silver-haired bat and the tricolored bat, two infrequently encountered bat species. The ecological relationships driving such outcomes extend beyond evolutionary increases in viral infectivity reported for these bat species (Messenger and others, 2003). Equally, if not more important, are factors that result in human contact with these species. Humaninduced landscape changes influence the distribution and abundance of animal populations, and these types of changes have had a major role in the ascension of wildlife rabies 
(Rupprecht and others, 1995) and likely will continue to do so. Bat-associated human disease emergence during recent years includes Nipah, Marburg, "Melaka," and Hendra viruses, and human Nipah virus infections clearly result from landscape changes that cause the bats to relocate their roosts to sites where interspecies disease transmission is facilitated (Daniels and others, 2007). That outcome emphasizes the importance of understanding bat ecology as a component of disease ecology.

Knowledge of bat ecology is especially important when humans and bats share environments. This information is needed to properly educate people about bats and for the application of preemptive actions, including education, for minimizing disease risks that may be present. Simple, inexpensive means for bat exclusion noted in the text can be installed to permit bats to depart from but prevent re-entry into buildings. This text also stresses the importance of house cats in the transmission of bat rabies, a situation that can largely be controlled by preemptive actions identified by the author and that many readers may apply to their daily lives with their pet cats.

Of special importance is the potential for contact between children and bats. Young people are often at higher risk for exposure to rabid bats because their uninhibited curiosity may result in their handling of moribund and injured bats, including those that may have been captured by the family cat. This writer had several personal experiences evaluating bats that were picked up by students, brought to grade school biology classes, and that proved to be rabid. Fortunately, no human rabies cases resulted from those events.

Education about bats provides valuable balance so that disease risks are not overstated, fostering fear of these species, or understated to the extent that people are placed at undue risk. Personal experiences have indicated that private sector presentations by those interested in bat conservation often understate disease considerations and demonstrate risky behaviors, such as handling bats without protective gloves, in efforts to overcome negative perspectives of bats advanced by others. These same types of indiscretions also appear in various publications (King, 1993).

The best defense against potential disease risks posed by bats, or any animal species, is a sound understanding of disease ecology and the wise application of that knowledge. Through this publication, Dr. Constantine strives to provide the reader with these attributes by sharing over a half-century of personal experiences and scientific investigations of bat rabies ecology. During his career, Dr. Constantine has significantly contributed to the scientific knowledge of this complex disease and challenged existing dogma in ways that have enhanced our current understanding of rabies transmission (see literature citations associated with the text). This unique and highly informative presentation incorporates anecdotes as well as hard science to provide both nonscientists and specialists with numerous points to ponder and a better understanding of bats as part of our biological world. The presentation is enhanced by the many illustrations that portray diversity among bat species, some of their adaptive features, and other aspects of bat biology. Bats have successfully colonized most regions of earth except for Antarctica and some other treeless northern areas of extreme cold (Kunz, 1982). These species need to be conserved for their ecological importance and for the benefits that they provide humans, rather than feared because of disease.

\section{Milt Friend \\ Emeritus Scientist USGS-National Wildlife Health Center}




\section{Acknowledgments}

This publication is due in large part to the help and cooperation provided the author by a great variety of workers during a lifetime of his investigations. Those individuals worked in fields such as public health, wildlife health, wildlife ecology and conservation, animal control, and also included landowners and land managers. Space does not allow detailing their individual contributions or listing all of them. Instead, I thank the multitude of those who have assisted my efforts and note those field companions who have made relevant contributions recalled during the development of this report. I have greatly enjoyed probing the secrets of nature with all of these individuals, some of whom are listed below by geographic area of shared exploration.

Africa: Dr. Lars Karstad.

Alaska: Dr. Robert L. Rausch, Dr. Raymond J. Hock.

California: Dr. Thomas J. Cade, Dr. William R. Dawson, Harry J. Fletcher, Christopher Henne, Gerry P. Mulcahy, Dr. Kenneth E. Stager, Dr. Joseph M. Szewczak, Raymond Williams, and Dr. Sherwin F. Wood.

California and Australia: Dr. Phillip Leitner, Dr. Elizabeth D. Pierson, and Dr. William E. Rainey.

Southwestern US, Mexico, and/or Central America: Devil B. Adams, Michael Balizan, Dr. Raúl Flores Crespo, Donald M. Goede, Dr. Louis N. Locke, Dr. G. Clay Mitchell, Richard W. Russell, Dr. Karl M. Schmidt, Dr. Bernardo Villa-R., Elliott J. Wescott, Jr., Loran M. Whitelock, and John R. Williams.

Trinidad, West Indies: Dr. Leonard V. Butcher, Dr. Vincent G. Moe, and Dr. Farouk Muradali.

Venezuela: Dr. Rexford D. Lord.

Brazil: Elisa Band, Dr. Nistan Fidalgo Peres, Dr. Takashi Fujii, and Dr. Otávio Diniz.

Thailand: Dr. David E. Davidson, Jr., Dr. Richard Luce, Dr. Boonlert Lumbertdacha, Dr. Charles E. Rupprecht, and Dr. Chakrapol Sriaroon.

Japan: Dr. Tatsuo Udagawa.

Worldwide: Kenneth G. Constantine

I also thank Drs. David Blehert and Milton Friend for their great assistance in the organization and development of this publication. 



\section{Contents}

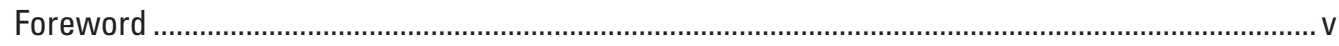

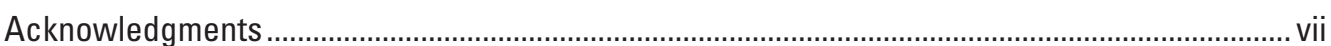

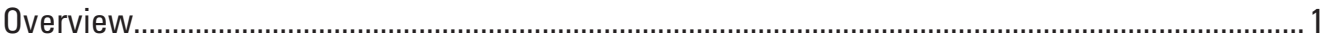

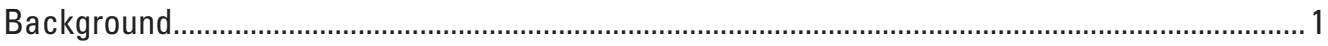

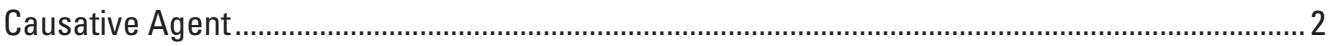

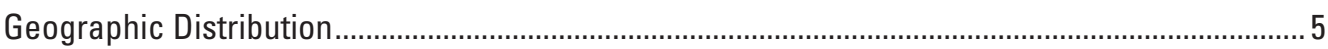

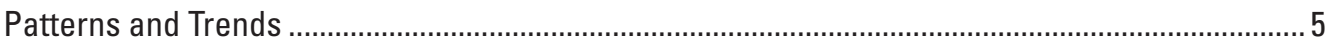

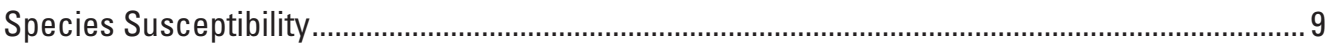

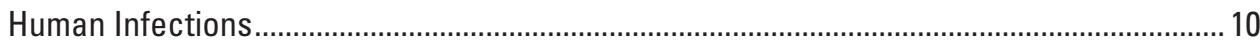

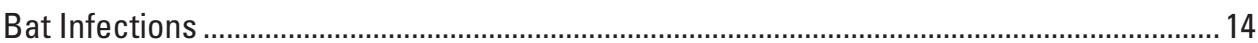

Infections in Other Species................................................................................................ 18

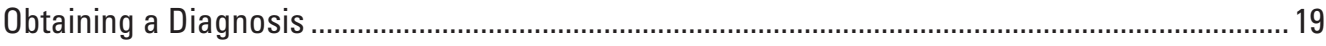

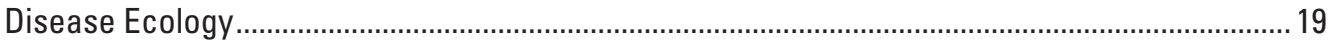

Bat Activity and Disease Patterns ......................................................................................... 19

Temperature and Rabies Virus Virulence ................................................................................ 22

How Colonial Bats Avoid Extinction by Lyssaviruses ............................................................ 22

Paralytic and Furious Disease Courses ............................................................................... 22

Viral and Host Species Diversity ....................................................................................... 25

Intraspecies and Interspecies Transmission of Bat Lyssaviral Variants.............................. 25

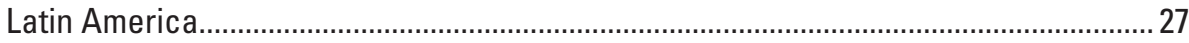

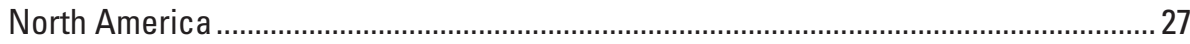

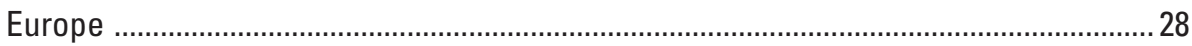

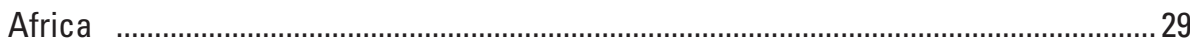

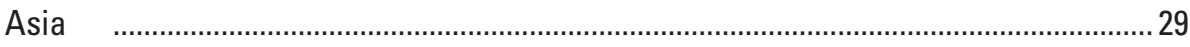

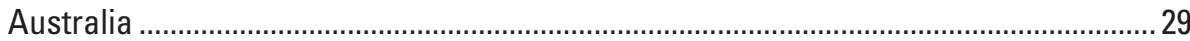

Environmental Persistence ....................................................................................................... 30

Points to Ponder: Interspecies Interactions in Potential Bat Rabies Transmission Settings ....... 32

Bat Colonies in Manmade Structures .......................................................................................... 32

Bat Colonies in Caves and Mine Tunnels................................................................................. 37

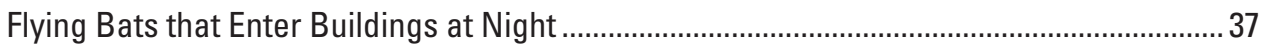

Unprovoked Attacks by Flying Rabid Bats........................................................................... 38

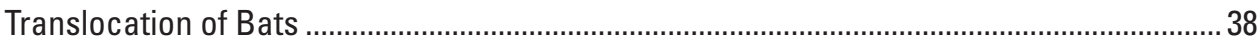

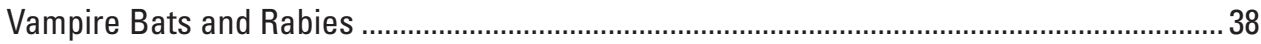

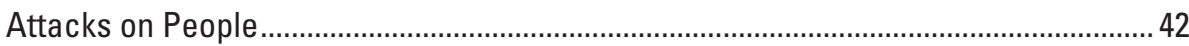

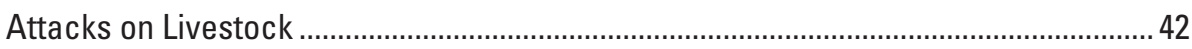

Attacks on Domestic Dogs and Cats ...................................................................... 42

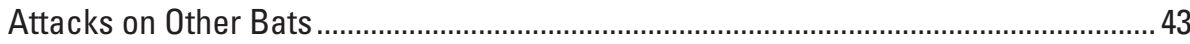

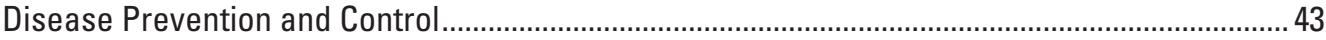

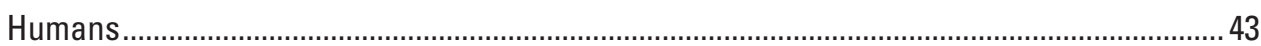

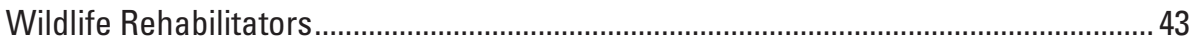

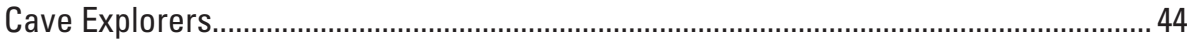

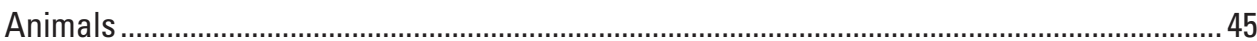

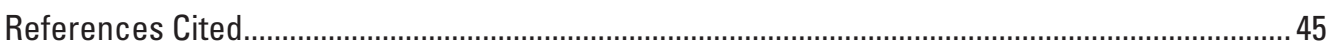

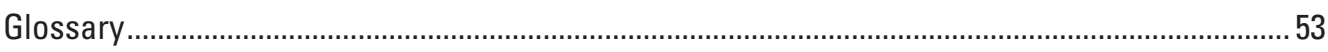




\section{Topic Highlight Boxes}

1. Vampires, Werewolves, and Settlement of the Americas ................................................ 3

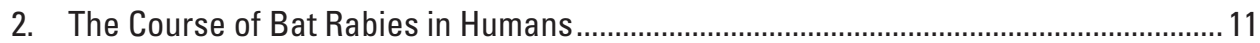

3. Human Survival of Clinical Rabies_-An Exception to the Rule....................................... 12

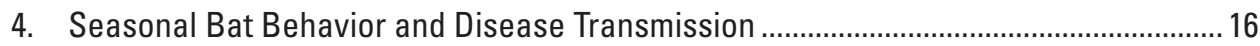

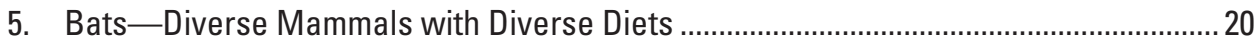

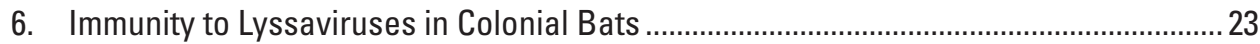

7. Bat Versus Bat —Interspecies Transmission of Bat Lyssaviruses .................................... 28

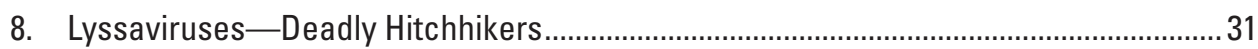

9. Domestic Cats and Lyssavirus Transmission .............................................................. 34

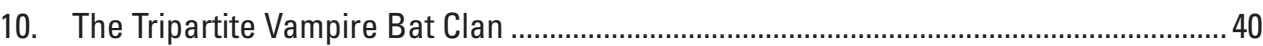

\section{Illustrations}

1. Unrooted phylogenetic tree based on complete lyssavirus $\mathrm{N}$ gene nucleotide sequences

2-3. Maps showing:

2. Number of bat species reported with rabies infections within the Americas .........6

3. Old World distribution of lyssavirus infections (excluding rabies virus) reported in bat species and humans in Africa, Asia, Australia, Europe, the Indian subcontinent, and the Middle East

4-6. Graphs showing:

4. Number of rabid bats identified in the United States from 1955 to 2006

5. Percentage of rabies-suspect bats identified as rabid in the United States from 1964 to 2006.

6. Number of rabies- and other lyssavirus-infected bat species by continent ...........10

7-17. Photographs showing:

7. Circular pattern of earth excavation resulting from confined body movement associated with posterior paralysis in a rabies-infected Zebu.

8. Townsend's big-eared bats awakening from hibernation

9. Brazilian free-tailed bats attempting to find roosting space among a dense colony of cohorts on a cave ceiling

10. Canyon bat in flight.

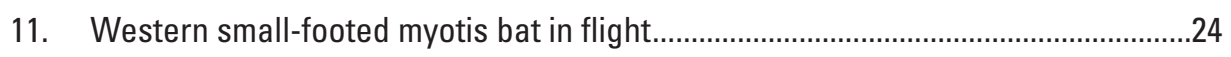

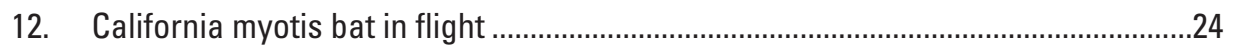

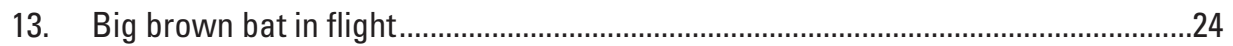

14. A mixed group of pallid and Brazilian free-tailed bats in an attic ...........................26

15. A Brazilian free-tailed bat and a Yuma myotis bat cooperating to conserve body heat.

16. A dead Brazilian free-tailed bat being consumed by dermestid beetles commonly found in association with bat colonies.

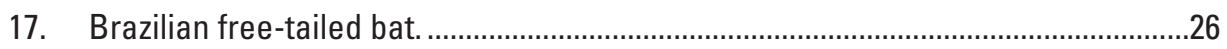

18. Diagram showing factors involved in cyclic fluctuations and environmental persistence of bat populations and lyssaviral infections. 
19-26. Photographs showing:

19. An evening foraging flight of Brazilian free-tailed bats ..........................................32

20. Brazilian free-tailed bats roosting under a railroad trestle .......................................33

21. A dead Brazilian free-tailed bat lying on the guano-covered floor

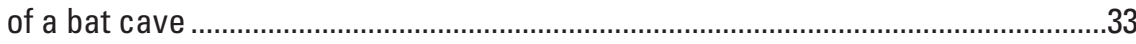

22. Exclusion devices permit bats to depart from but prevent re-entering the interior of a building ......................................................................

23. Researcher among a Brazilian free-tailed bat colony............................................37

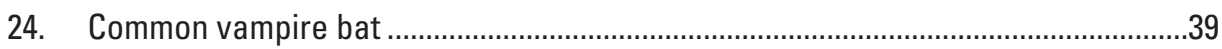

25. Application of anticoagulant jelly to the back of a vampire bat ...............................39

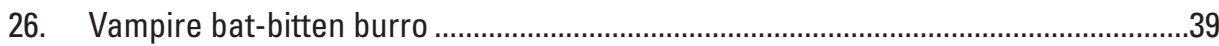

\section{Tables}

1. Lyssavirus infections in mammals: agents, hosts, identification, and effectiveness of antirabies prophylaxis measures for humans .................................2

2. General geographic area of rabies-related lyssavirus infections

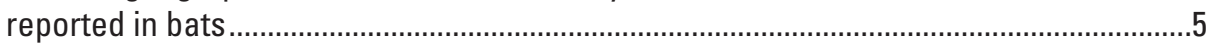

3. Bat families in the USA reported with bat rabies ..........................................................

4. Insectivorous bat origins of human rabies infections recognized

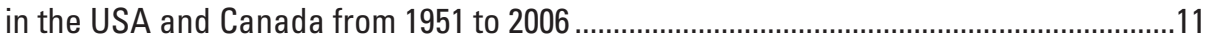

5. Human nonrabies lyssaviral infections reported in Africa, Asia,

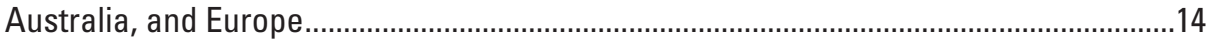

6. Examples of incubation periods and times to death relating to human mortalities from bat-associated lyssavirus exposure ........................................15

7. Examples of nonbat species infected by rabid bats ......................................................18

8. Examples of vampire bat rabies variants found in other species

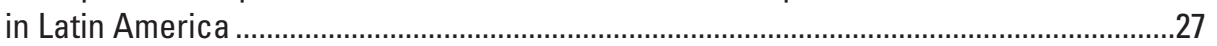

9. Diseases other than rabies that may be transmitted by vampire bats .............................42

10. Preemptive actions for minimizing human exposures to lyssaviruses...............................44

\section{Appendixes}

A. Bat Species Reported Infected with Rabies in the USA from 1953 to 2007.

B. Bat Species Reported Infected with Rabies in the Americas

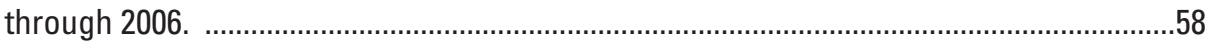

C. Common and Scientific Names for Species Cited .........................................................61

D. Lyssavirus Infections in Bats Reported in Africa, Asia, Australia,

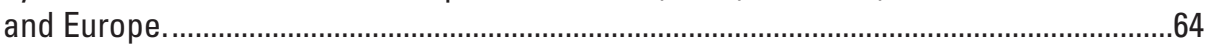

E. Course of Bat Lyssavirus Infections in Humans ............................................................66

Words in bold type in the text, the topic highlight boxes, and the tables are defined in the Glossary. 


\section{"What shall I do? What can I do? How can I escape from this}

dreadful thing of night and gloom and fear?"

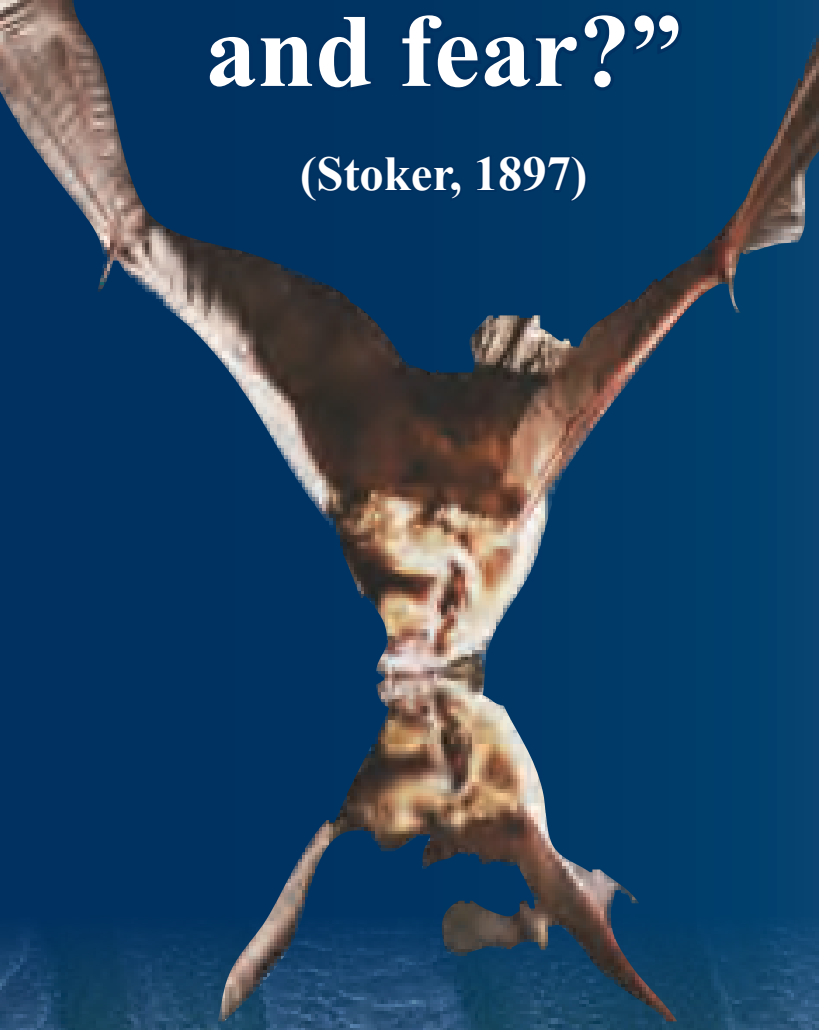

sgre Who shall eat the tongule or the heart of a bat shall thee from water and die.? ((R)hazes, 10th eentury Persian physician, quoted by Aldrovandi, 1599)) Top: A big brown bat dainking on the wing is reflected in the water below. (D.G. Constantine) 


\title{
Bat Rabies and Other Lyssavirus Infections
}

\author{
By Denny G. Constantine
}

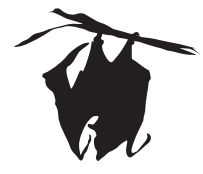

Synonyms

Rabia en murciélagos (Spanish)

Raiva em morcegos (Portuguese)

Rage de chauves-souris (French)

Tollwut bei fledermäusen (German)

\section{Overview}

Rabies constitutes a nearly global viral disease of mammals that affects the central nervous system, is usually transmitted by bite, and typically results in the death of the host. The causative agent is a member of the lyssavirus group (Niezgoda and others, 2002). Each Lyssavirus species is divisible into strains called variants, each of which usually is found only in an individual reservoir host species of carnivore (Order Carnivora) or bat (Order Chiroptera), within which the virus multiplies (Table 1; Rupprecht and others, 2001). Humans and other species are infected through contact with a host animal. Bats are the focus for this synopsis (Box 1), and they are known to be infected throughout the Americas and in Europe, Asia, Africa, and Australia (Niezgoda and others, 2002). Both suborders of bats, the Megachiroptera or large fruit-eating bats of the Old World tropics, and the Microchiroptera, consisting of all other bats distributed globally to the limits of tree growth, are known to become infected with variants of lyssavirus. Bat species known to be rabies infected in the USA and the Americas are listed in Appendixes A and B, respectively.

\section{Background}

The origin of rabies, as of many other infectious diseases, is a matter of speculation. It has been postulated that rabies viruses may have originated from an insect virus that infected insect-eating bats some 7,000 to 12,000 years ago (Badrane and Tordo, 2001). Three such insect viruses, proposed for inclusion in the Lyssavirus genus, are known today. Moreover, data and calculations have been presented to support the view that after rabies viruses evolved in bats between 900 to 1,500 years ago, the infection subsequently spilled over into carnivorous mammals (Badrane and Tordo, 2001). Bats and carnivores are essentially the only natural or persistent reservoir hosts of rabies known today, and individuals of other mammal species usually die without spreading the infection.

North American bats north of Mexico, nearly all of them insectivorous, were ignored as potential rabies hosts until 1953 when the father of a bitten child, aware of the infection spread by vampire bats, insisted that the biting bat be tested. After the bat was determined to be rabid (Venters and others, 1954), surveys were conducted until the virus was found throughout the continent in all bat species that were extensively tested. Whereas only 0.1 percent of seemingly healthy bats were infected, 10 percent of bats that were rabies-suspect, because they were found ill or were dead, were positive for rabies infection (Constantine, 1988a). 
Findings in North America soon stimulated surveys throughout the world. These surveys focused on sampling colonies of healthy bats, and they generally yielded negative results, such as those from North America. However, the testing of symptomatic bats eventually produced rabies viruses that differ from typical carnivore rabies isolates (Hentschke and Hellman, 1975; Mohr, 1957; Pitzschke, 1965). Interest in bat rabies has varied with time. For example, European bat rabies was identified in the laboratory only 14 times over 30 years. Then, in 1985, three European human rabies deaths following bat bites were reported (Lumio and others, 1986; Selimov and others, 1986), causing such increased effort that by the end of 1989, 4,705 European bats had been tested, 379 ( 8 percent) of which were found to be infected (Kappeler, 1989). Additional cases in bats and other mammals were discovered in Africa and Asia. In Australia, where rabies was believed to be absent, rabies infection was reported in adequately sampled bat species ranging from small insecteaters to large fruit-eating bats known as flying foxes.

\section{Causative Agent}

Classical rabies has been known for centuries and it is caused by the most widespread of seven similar virus species (also called genotypes, as each species is defined by phylogenetic analysis of viral genes) within the genus Lyssavirus (McColl and others, 2000). Four additional putative Lyssavirus species were discovered recently and their taxonomic positions are under study (Kuzmin and others, 2005) (Fig. 1). Discoveries of additional lyssaviruses are likely to follow. Whereas classical rabies is well known, other lyssavirus species were not identified prior to 1956; thus, far less is known about them. For practical purposes, all lyssavirus species potentially produce rabies-like infections, so all are included in this publication. Lyssavirus is an appropriate name for these viruses as "lyssa" means rage, fury, or canine madness in Greek.

Table 1. Lyssavirus infections in mammals: agents, hosts, identification, and effectiveness of antirabies prophylaxis measures for humans.

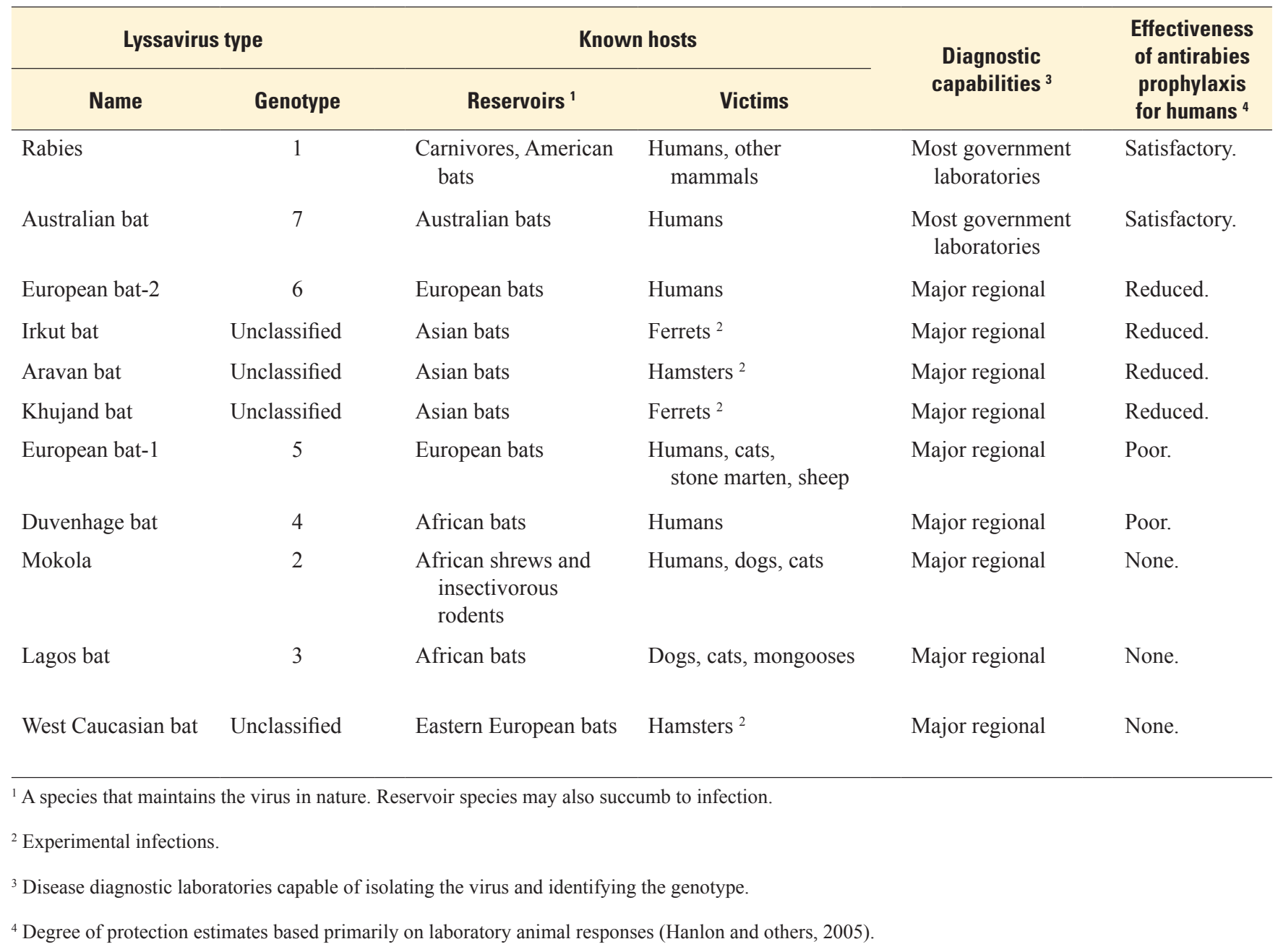




\section{Vampires, Werewolves, and Settlement of the Americas}

Bat-borne rabies, perhaps especially involving common vampire bats, may have inspired or influenced early tales of human vampires in Europe. The patterns of serial transmission by bite and the dreadful transformation of victims are strikingly similar. Correspondingly, rabies may have contributed to tales of werewolves and the transformation of their worldwide counterparts into various carnivorous mammals, perhaps influenced by cases of "barking" human rabies victims or of attacks by some infected human victims on other people.

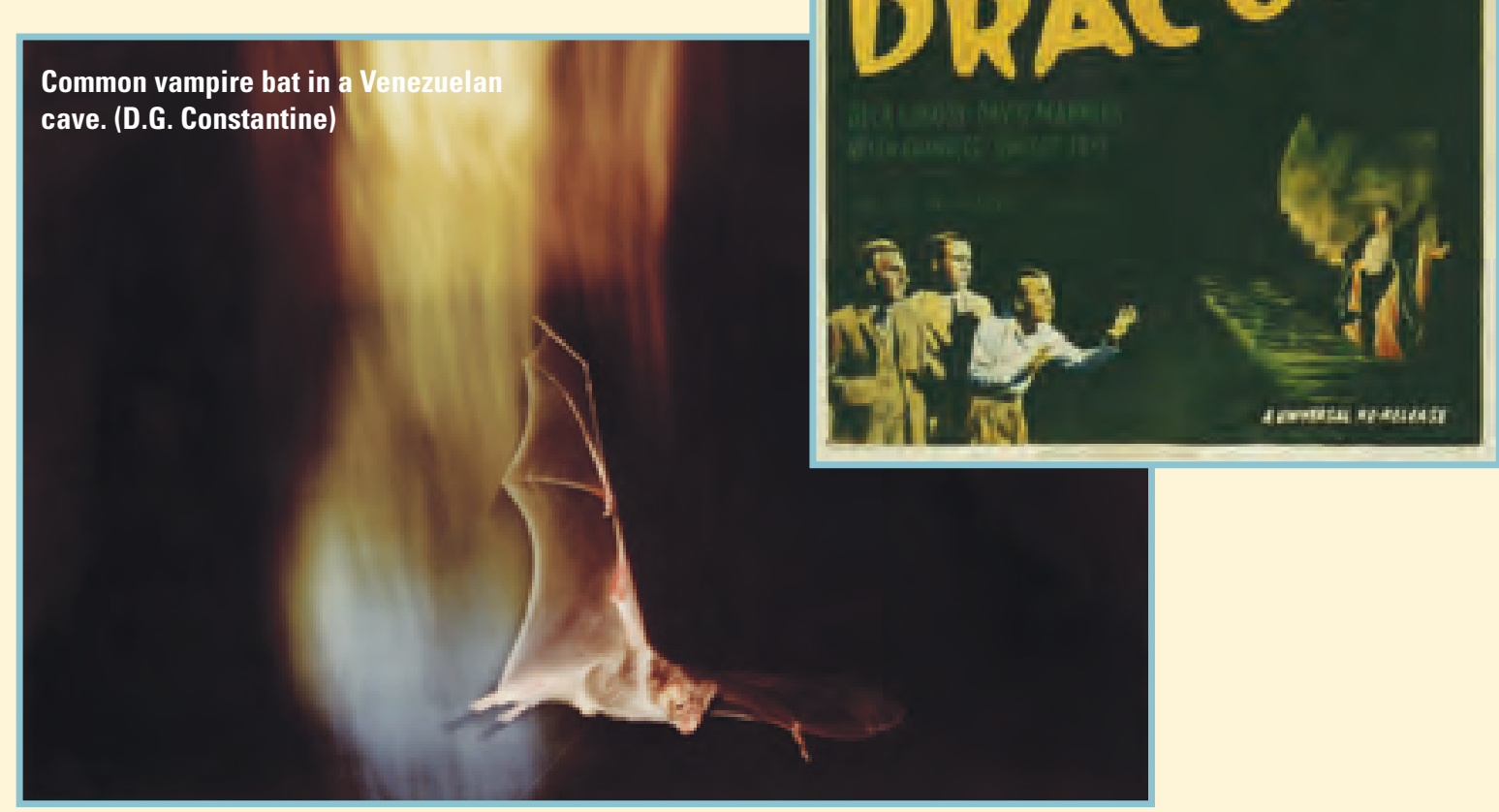

Vampire bats also were likely causes of rabies prior to the arrival of European explorers in the Americas, and the rabies-like deaths of explorers in tropical America caused by "venomous bites" of vampire bats were reported in the $16^{\text {th }}$ century. At that time, native peoples attempted to prevent rabies infections by cleansing the sites of vampire bat bites and cauterizing the wounds with wood embers (d'Anghiera, 1555; De Oviedo y Valdes, 1526). Subsequent outbreaks of rabies in humans and their domestic animals plagued Latin America and prevented the development of extensive areas, problems that continue today. The infection eventually was found in various other tropical American bat species that specialize in diets consisting of fruit, pollen, nectar, insects, fish, or other vertebrates. 
Prudence suggests that all lyssaviruses should be regarded as dangerous as classical rabies and, thus, likely to be lethal for humans and other mammals. The hazards can be even greater because not all of these viruses are readily identifiable by standard rabies diagnostic methods (Table 1). Furthermore, except for Australian bat lyssavirus, other lyssavirus infections are not dependably preventable by available rabies vaccines and rabies hyperimmune sera. For example, no biologics are available to prevent infection from the Lagos bat, Mokola, or West Caucasian bat viruses, and current rabies biologics have variably reduced effectiveness against the other currently known lyssaviruses (Hanlon and others, 2005).

Based on knowledge of rabies and most other lyssaviral species, each lyssaviral species may prove to be divisible into variants. Each variant typically is found in a single species of reservoir host, and it apparently develops after its precursor is transmitted to a new host species. For example, a different bat lyssaviruss may evolve after it is transmitted from one bat species to another bat species, within which it subsequently reproduces in isolation, becomes differentiated from the original lyssavirus, and as time progresses, it becomes increasingly efficient in establishing itself in the second bat species. After a variant is transmitted from its reservoir host to an atypical or aberrant host species, a dead-end infection usually results because the maladapted atypical host quickly dies before the virus can be transmitted further. Identification of variants that infect atypical hosts, such as humans, usually points to a particular natural reservoir host species, such as a species of carnivore or bat, as the source for the human infection.

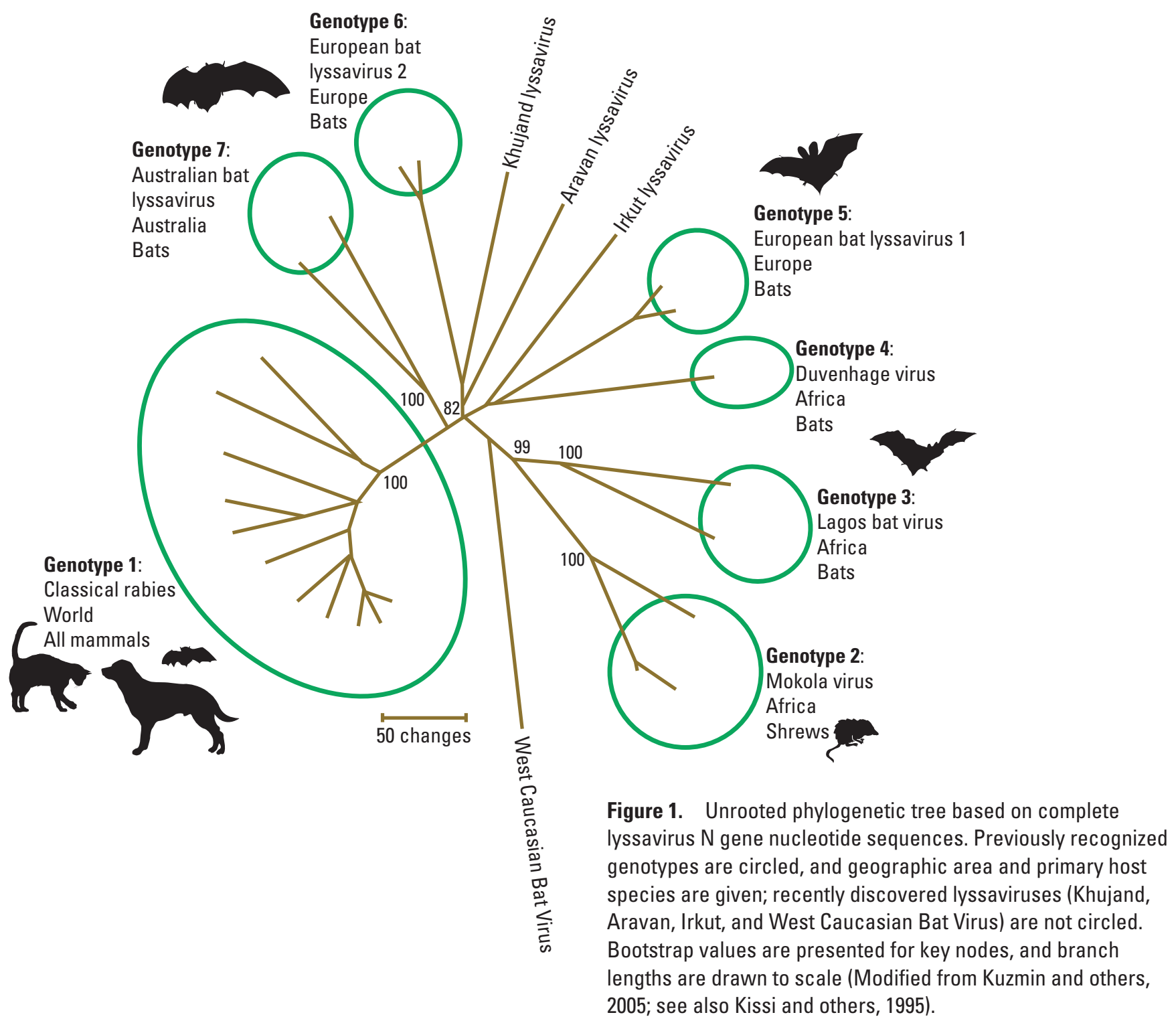




\section{Geographic Distribution}

Although bat lyssavirus infections have a broad geographic distribution (Figs. 2 and 3), our knowledge of lyssavirus distribution is incomplete for various reasons, including underreporting (Table 2). In some instances, reporting is inhibited by apprehension over the potentially suppressive effects on development or tourism. At best, reporting requires the presence of people to detect infected bats. For example, many cases in the USA are reported from cities, but unpopulated or sparsely populated areas often are devoid of reports. Nevertheless, lyssavirus infections have received considerable attention in the Americas and they are now known wherever bats are found. Eventually, lyssavirus infections may be found globally except for treeless areas and some isolated islands.

\section{Patterns and Trends}

Changes in human perception and increased research efforts have improved understanding of bat lyssavirus infections in bats, humans, and other mammals. Although vampire bat-borne rabies infected humans prior to European explorations in tropical America, the viral cause was not discovered until over 400 years later (Carini, 1911). Knowledge of the existence of vampire bat rabies stimulated research to enhance understanding of the extent and the gravity of infec- tion and led to the development of methods for combating it. However, resource allocations for these efforts have been inconsistent and have fluctuated greatly. Consequently, the history of bat lyssavirus infections in general and their suppressive effects on geographic and economic development in the Americas are incompletely known. By 1969, the Food and Agricultural Organization of the United Nations concluded that cattle deaths and indirect losses caused by vampire bats cost Latin America over one-third of a billion dollars annually (Steele, 1969). Since then, relief has been provided through development of vampire bat control techniques and rabies vaccines. These advances have largely been supported and coordinated by the Pan American Health Organization (Belotto, 2005).

The 1953 discovery in the USA of bat rabies transmitted by bats other than the vampire bat (Appendix A) stimulated a major research effort that resulted in the disclosure of increasing numbers of cases (Fig. 4). These findings supported the popular conclusion that bat rabies was a new and growing problem. However, case increases proved to be proportional to investigative effort, with growing numbers of bats tested as time progressed (Fig. 5) (Constantine, 1967a). News coverage is another factor leading to local increases in the submission of bats to be tested and to corresponding increases in reported cases. In addition, technological advances have increased the application of rabies virus variant identification techniques and are yielding greater numbers of human rabies cases attributed to bats. During 2006, 1,692 cases of rabies in bats were reported in the USA.

Table 2. General geographic area of rabies-related lyssavirus infections reported in bats.

[Unknown indicates that the lyssavirus species was known only to be rabies-related]

\begin{tabular}{|c|c|c|c|c|c|c|}
\hline \multirow{2}{*}{$\begin{array}{l}\text { Lyssavirus } \\
\text { species }\end{array}$} & \multicolumn{6}{|c|}{ Number of bat species reported infected } \\
\hline & Africa & Australia & Asia & Europe & $\begin{array}{c}\text { Indian } \\
\text { subcontinent }\end{array}$ & $\begin{array}{c}\text { Middle } \\
\text { East }\end{array}$ \\
\hline Aravan & & & 1 & & & \\
\hline Australian & & 5 & & & & \\
\hline Duvenhage & 1 & & & & & \\
\hline European-1 & & & & 9 & & \\
\hline European-2 & & & & 7 & & \\
\hline Irkut & & & 1 & & & \\
\hline Khujand & & & 1 & & & \\
\hline Lagos & 4 & & & & & 1 \\
\hline West Caucasion & & & & 1 & & \\
\hline Unknown & 1 & & 3 & 7 & 2 & 1 \\
\hline Total: & 6 & 5 & 6 & 24 & 2 & 2 \\
\hline
\end{tabular}




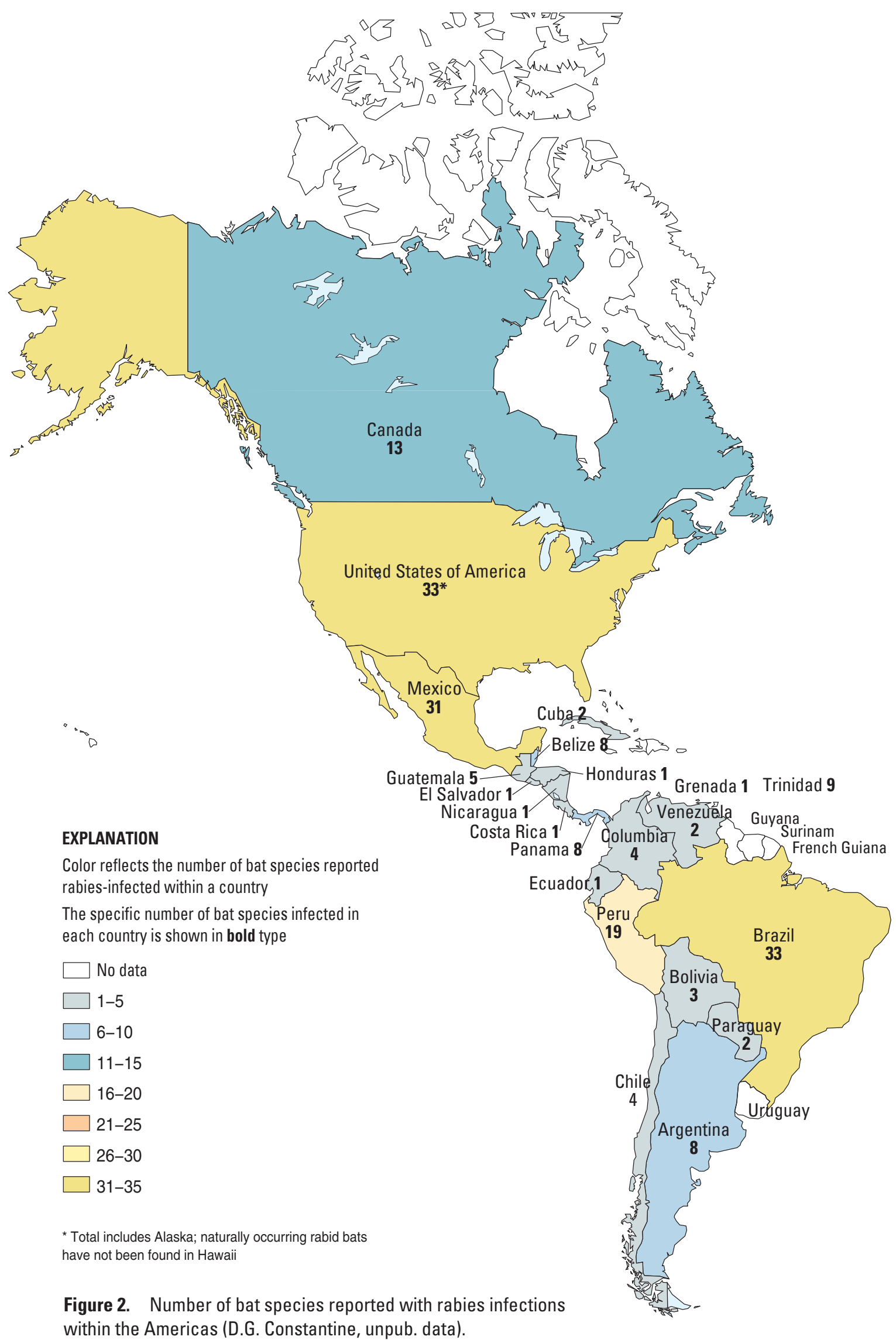




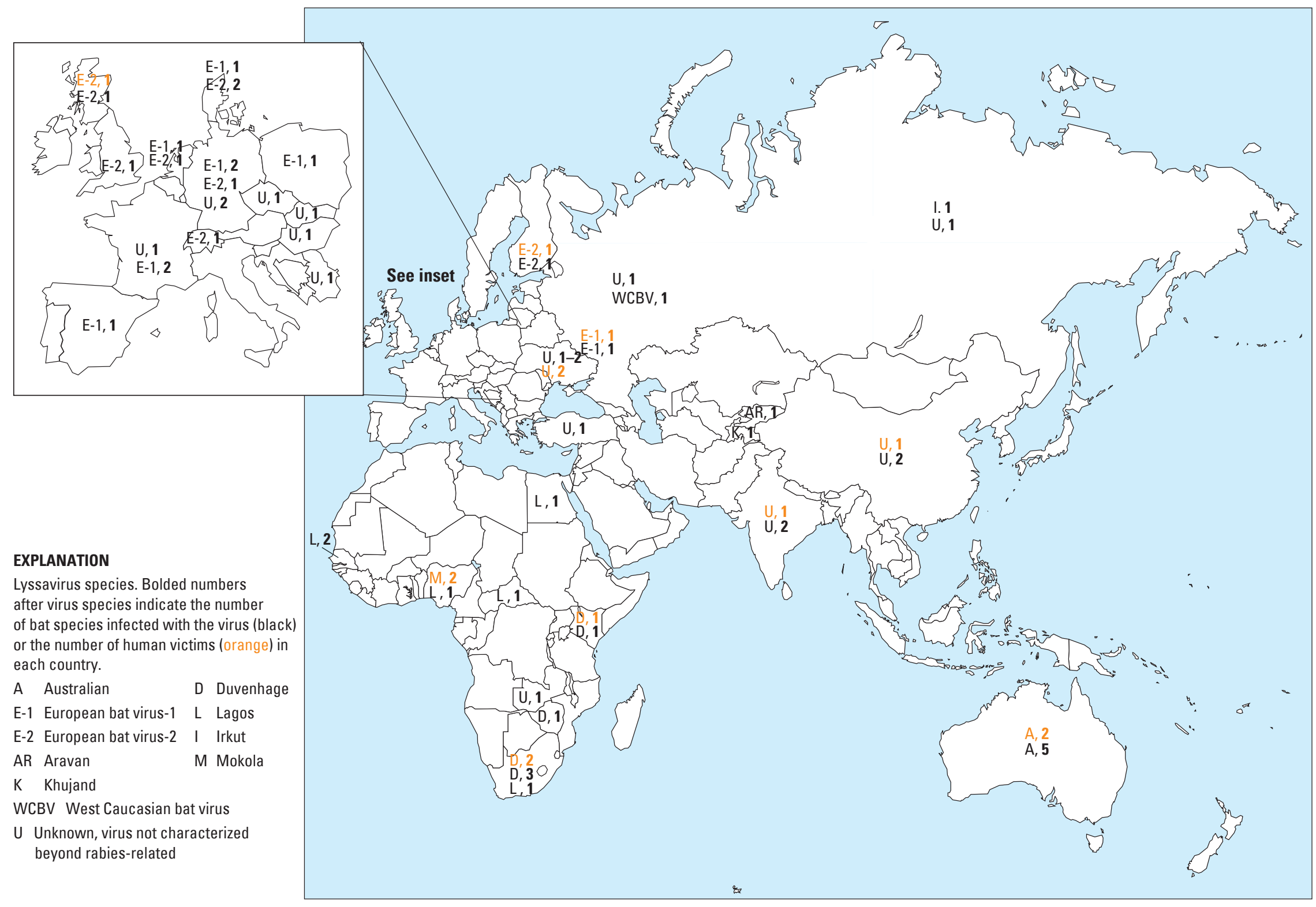

Figure 3. Old World distribution of lyssavirus infections (excluding rabies virus) reported in bat species (black) and humans (red) in Africa (Boulger and Porterfield, 1958; Crick and others; 1982; Foggin, 1988; Familusi and others, 1972; Foggin, 1988; Markotter and others, 2006a; Meredith and others, 1971; Paweska and others, 2006; Sureau and others, 1980; van Thiel and others, 2008), Asia (Arai and others, 2003; Kuzmin and others, 2003; Tang and others, 2005), Australia (Allworth and others, 1996; McColl and others, 2002; Warrilow and others, 2003), Europe (Amengaul and others, 1997; Botvinkin and others, 2003; Bruyère and Janot, 2000; Bruyère-Masson and others, 2001; Fooks and others, 2002; Hentschke and Hellman, 1975; Johnson and others, 2006; Kappeler, 1989; Kerekes, 1999; King and Crick, 1988; Khozinski and others, 1990; Kuzmin and others, 2005; Lumio and others, 1986; Matouch, 1999; Nikolíc and Jelesíc, 1956; Pérez-Jordá and others, 1995; Serro-Cobo and others, 2002; Tunçman, 1958; Selimov and others, 1991; Van der Poel and others, 2003; WHO Collaborating Centre for Rabies Surveillance and Research, 1999), the Indian subcontinent (Pal and others, 1980; Veeraraghavan, 1955), and the Middle East (Picard-Meyer and others, 2004). 
Figure 4. Number of rabid bats identified in the United States from 1955 to 2006.

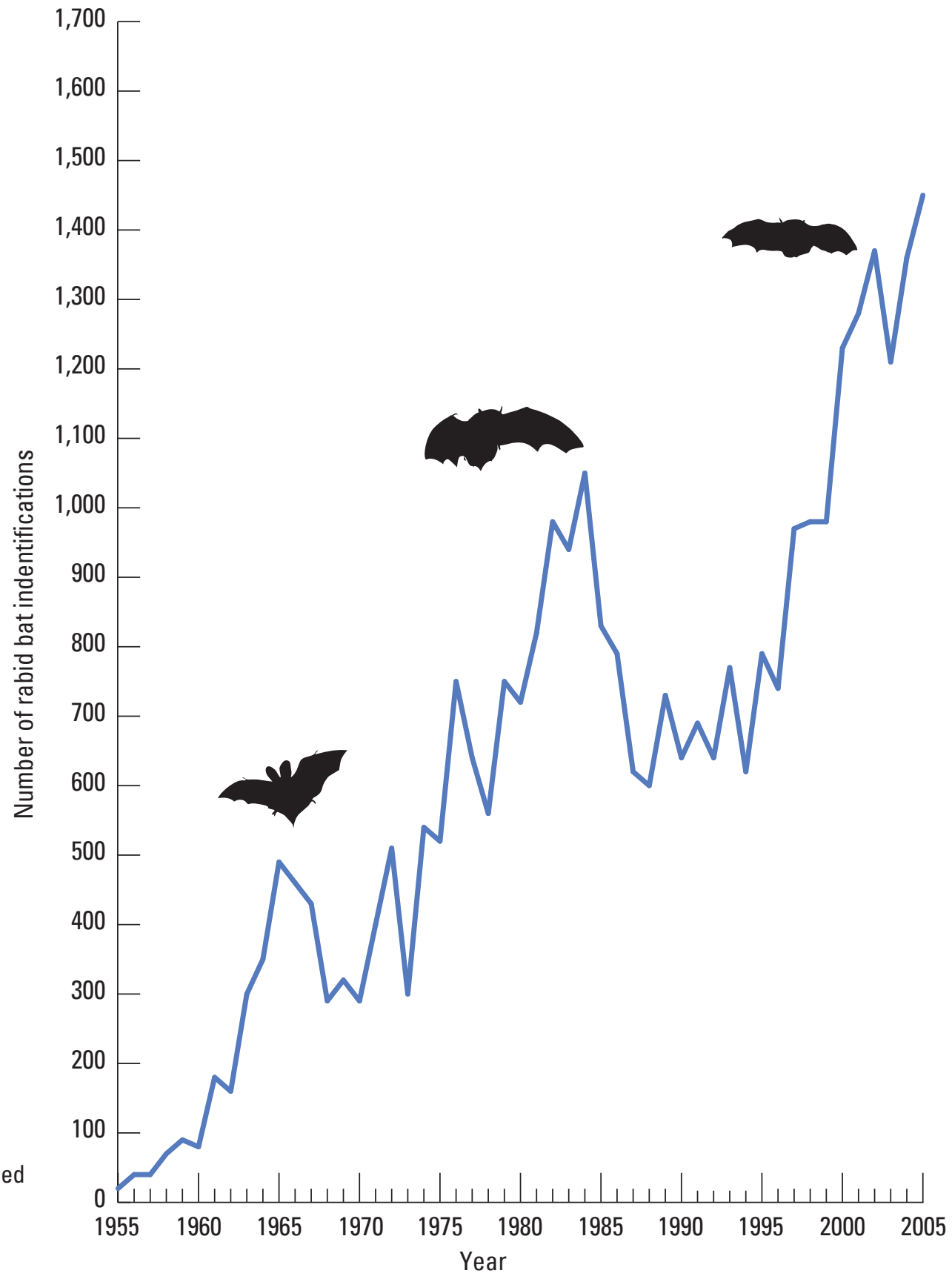
Control and Prevention data. 


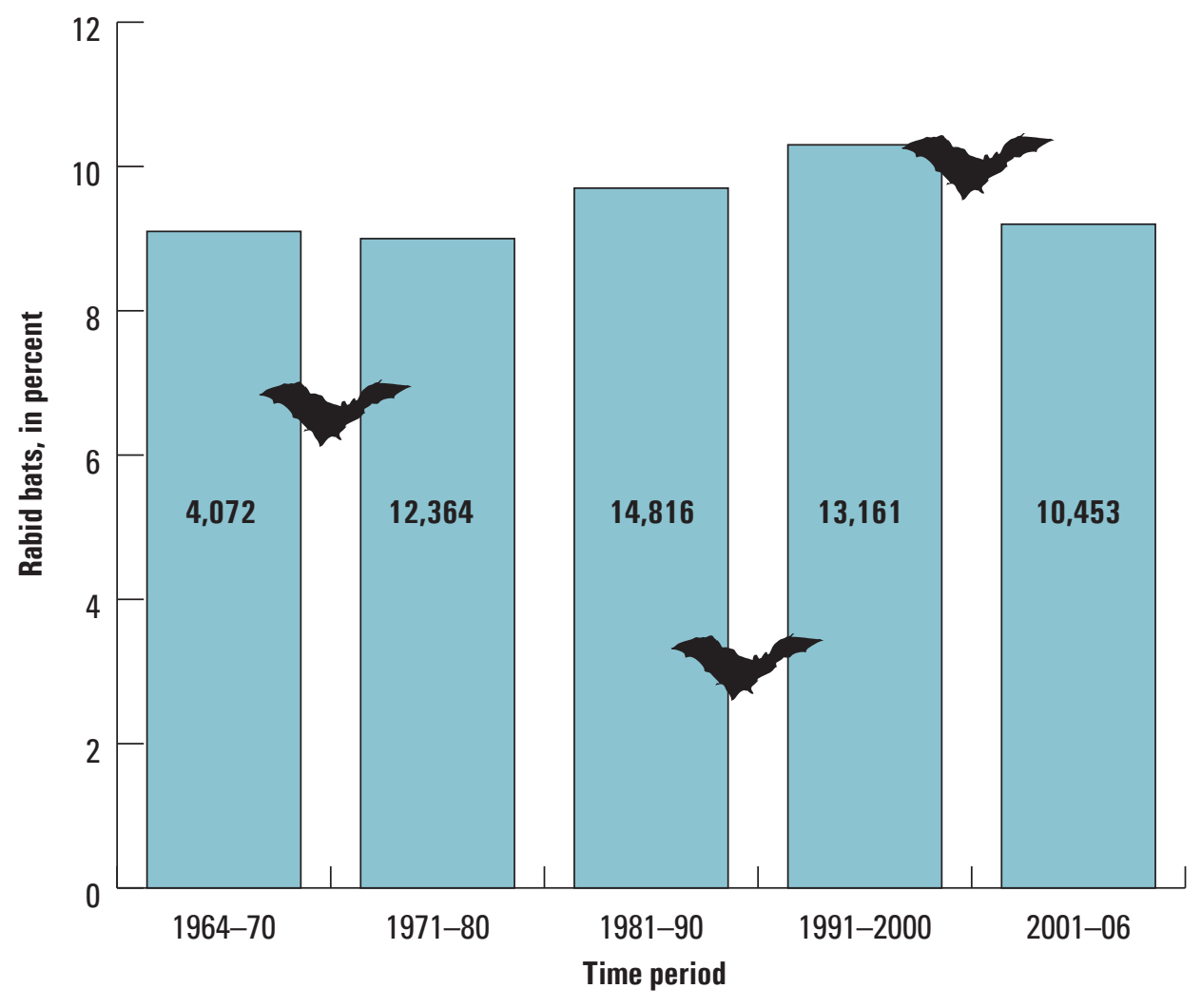

Figure 5. Percentage of rabiessuspect bats identified as rabid in the United States from 1964 to 2006. The first documented bat rabies case in humans was identified in 1953; bat rabies surveillance records are unsatisfactory for 1954-63. (Bold numbers indicate the number of bats tested during the indicated time period. Compiled from U.S. Centers for Disease Control and Prevention data.)

\section{Species Susceptibility}

It has long been assumed that all mammals are susceptible to rabies infection, a view that may apply in varying degrees to the other lyssaviruses as more is learned about them. No gross lesions aid in the identification of lyssavirus infections, so diagnosis of living or dead untested subjects is tentative and based on history, which usually includes reports of behavior that is not specific to the disease. Rabies virus is known to be maintained within two reservoir host mammal groups, carnivores and bats, and carnivores host virus variants that differ considerably from those hosted by bats (Constantine, 1967a). Rabies and other lyssavirus infections have been reported from 114 bat species (Appendixes B and D), including 33 in the USA (Appendix A; Table 3). Australia has the fewest number of bat species (five documented) with lyssavirus infections; the numbers of infected species for Asia, Africa, and Europe also are low (Appendix D; Fig. 6). The lyssaviruses identified from infected bats represent 10 (including rabies) of the 11 currently named or putative genotypes for this virus group, and several of the lyssaviruses from bats remain unclassified (Table 1). Thus, there is adequate reason to regard all lyssaviruses to be potentially as deadly as classical rabies.
Table 3. Bat families in the USA reported with bat rabies.

\begin{tabular}{llc}
\hline \multicolumn{1}{c}{ Family } & Food habits & $\begin{array}{c}\text { Number of } \\
\text { infected species }\end{array}$ \\
\hline Phyllostomidae & Omnivorous ${ }^{1}$ & 1 \\
Mormoopidae & Insectivorous & 1 \\
Molossidae & Insectivorous & 4 \\
Vespertilionidae & Insectivorous & 27 \\
\hline
\end{tabular}

${ }^{1}$ Members of this diverse family of neotropical bats feed upon insects, small vertebrates, blood, fruit, nectar, and pollen.

The results of exploratory rabies transmission experiments provided the first indication of the existence of viral variants. These experiments demonstrated that the spectrum of carnivores susceptible to infection differed according to the bat species origin of rabies virus, as did incubation periods, duration of illness, and morbid behavior (Constantine, 1967a). Maladaptations, such as the death of the host before the virus can reach the saliva for transmission, reveal why infections of new, unadapted host species may, in effect, be dead end. 
Figure 6. Number of rabies- and other lyssavirus-infected bat species by continent.

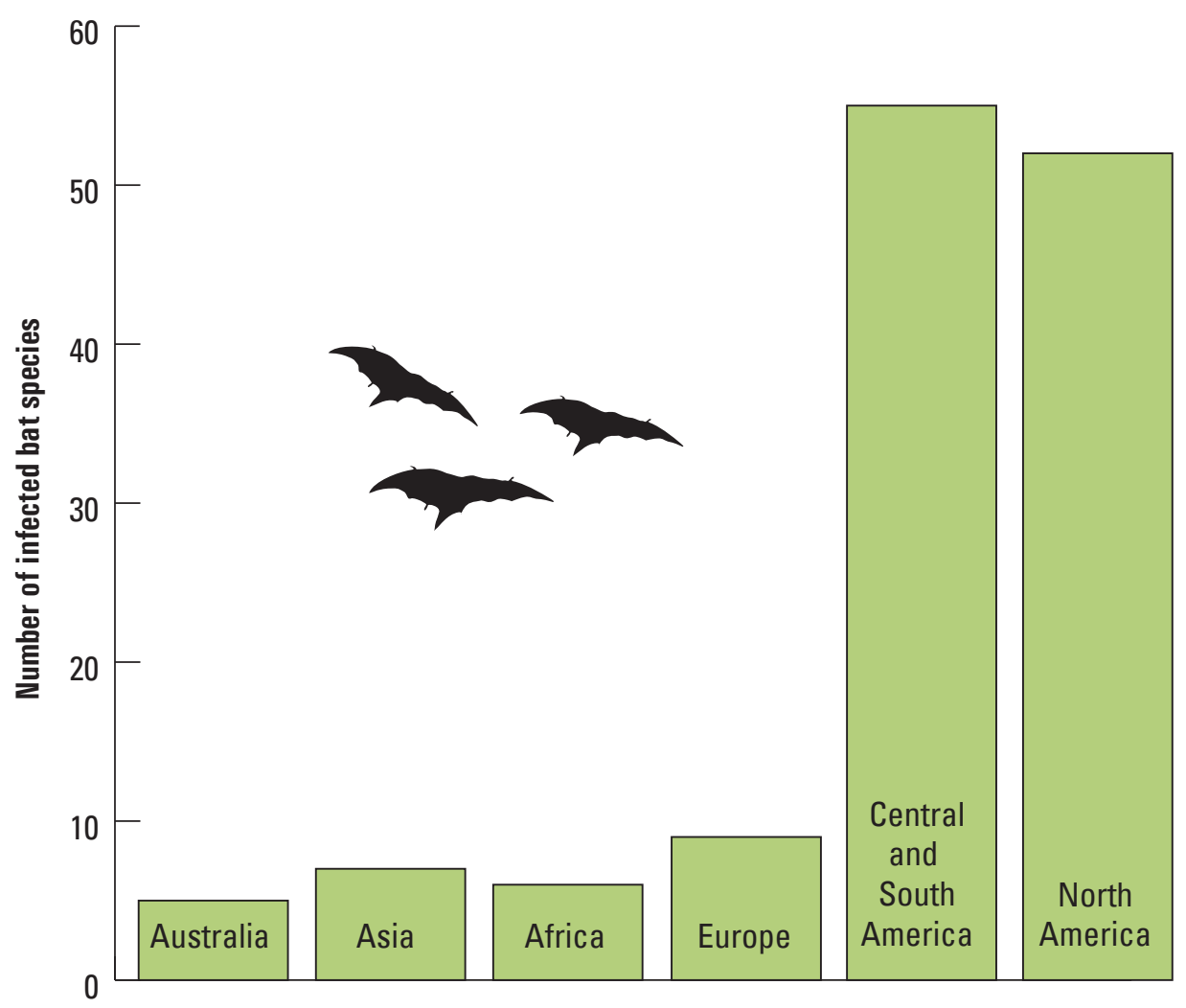

\section{Human Infections}

Each year as many as 100,000 people globally may die of rabies (Rupprecht and others, 1995), and ten million people take antirabies treatment (Goswami and others, 2005). Carnivores, principally dogs, are the vectors for the great majority of rabies transmissions to people in developing areas. In Latin America, thousands of people must have died, and hundreds continue to perish due to vampire bat-borne rabies, but case reports are lacking from some countries, particularly from their remote regions. Due to competition for limited resources for research of the causes of human mortality, vampire bat rabies infection in humans, especially those living in inaccessible areas, did not receive adequate attention until recently (Navarro Vela, 2001; Takoaka and Omoto, 2001; Vargas Pino, 2001). Reports of human rabies due to bats other than vampires are difficult to discern because of local inability to differentiate vampire bats from any of the great variety of bat species in Latin America.

The recognition of human lyssavirus infections of bat origin exists to varying degrees in developed countries. The existence of bat rabies and associated human mortality in North America north of Mexico was unknown prior to the 1950s. Between 1951 and 2006, 51 recognized human rabies cases in the USA and Canada were determined to be of insectivorous bat origin (Table 4), and there is some evidence that bat rabies existed before 1951 in these countries (Christensen, 1946; Constantine, 1967b). This revelation of bat-associated human rabies mortality as a result of public health investigations has been mirrored elsewhere for other lyssaviruses (Table 5).

The onset of clinical disease in humans infected by rabies virus nearly always results in death (Box 2). Exceptions are so noteworthy as to be the subject for scientific reports (Hattwick and others, 1972; Porras and others, 1976; Willoughby and others, 2005; Box 3). Examples of the course of disease in humans infected by bat lyssaviruses (Appendix E) illustrate the consequences of those infections and the variability in incubation time between exposure and the onset of clinical disease (Table 6). 


\section{The Course of Bat Rabies in Humans}

Rabies in humans is characterized by a variable incubation period, usually from 1 to 3 months, but ranging from 10 days to a year or more. The disease then generally develops in three phases: prodromal, excitatory, and paralytic (Fishbein, 1991). Prodromal signs last from 2 to 10 days, are nonspecific, and include slight fever, malaise, headache, nausea, dilation of the pupils, sore throat, anxiety, irritability, and perhaps sensitivity to wind, bright light, and noise. More significant are abnormal sensations such as pain, burning, cold, and itching or tingling near the site of virus entry, such as a bite.

The excitatory phase, present in 80 percent of cases, may be absent, rapidly transitory, last 1 week, or continue until death. During this phase, victims experience increasing anxiety, apprehension, and melancholia. Muscles around the virus entry site may weaken. Eyes may undergo unusual or uncoordinated movements, pupils may undergo asymmetric dilation or constriction, and eye corneas may be insensitive to touch. Facial muscles may weaken and hoarseness develops. Other signs can be alterations in heart rate and intensity, respiratory rate and depth, urinary retention followed by overflow incontinence, and constipation. The classical manifestation of rabies in humans is hydrophobia, when upon attempts to swallow liquid, the victim forcefully expels it due to the involuntary contraction of the muscles involved in swallowing and respiration. This reaction is subsequently repeated if the victim is provoked by the sight or sound of liquids. The convulsive attack may cause death through choking and failure to breathe. The victim may suddenly die from respiratory arrest or death may be preceded by coma.

Paralysis, which predominates in 20 percent of cases, may precede death by 1-4 weeks. Swallowing is possible but becomes difficult. A general flaccid paralysis develops. Apathy progresses to stupor, followed by coma, peripheral vascular collapse, and death.

Table 4. Insectivorous bat origins of human rabies infections recognized in the USA and Canada from 1951 to 2006.

\begin{tabular}{llccc}
\hline \multicolumn{1}{c}{ Bat species } & Family & $\begin{array}{c}\text { Number of bat } \\
\text { carcasses } \\
\text { identified } \\
\text { taxonomically }\end{array}$ & $\begin{array}{c}\text { Number of } \\
\text { Iyssaviruses } \\
\text { identified to the } \\
\text { variant level }\end{array}$ & $\begin{array}{c}\text { Total number of } \\
\text { bats involved in } \\
\text { human rabies } \\
\text { infections }\end{array}$ \\
\hline Brazilian free-tailed bat & Molossidae & 7 & 10 & 10 \\
Big brown bat & Vespertilionidae & 2 & 13 & 3 \\
California myotis & Vespertilionidae & 1 & 1 & 1 \\
Myotis sp. & Vespertilionidae & 0 & 11 & 11 \\
Silver-haired bat & Vespertilionidae & 1 & 17 & 17 \\
Tricolored bat & Vespertilionidae & 0 & $\mathbf{4 3}$ & 2 \\
\cline { 2 - 5 } Totals & & $\mathbf{1 1}$ & 11 \\
\hline
\end{tabular}

\footnotetext{
${ }^{1}$ Variants were an Ef (Big brown bat)-associated, a Ps (Tricolored bat)-associated, and an undetermined variant.

${ }^{2}$ Total includes eight bats for which neither the bat taxonomic identity nor the virus variant were determined.
} 


\title{
Human Survival of Clinical Rabies-An Exception to the Rule
}

\begin{abstract}
Cases of patients surviving rabies infection after the appearance of clinical signs, without preexposure vaccination or postexposure prophylaxis or both, are rare. However, two cases of patients surviving clinical rabies are well documented. The first case was a 6-year-old boy in Ohio (Hattwick and others, 1972), and the second was a 15-year-old girl in Wisconsin (Willoughby, Jr., and others, 2005). Both patients were exposed to rabies through bat bites. In each case, aggressive supportive treatment was given to avoid or decrease the known or anticipated ravages of the disease. The reasons for the success of the administered treatments are not fully understood, but the positive outcomes offer incentives for continuing research efforts.
\end{abstract}

\section{Case 1}

A 6-year-old boy was bitten on his left thumb by a rabid big brown bat on October 10, 1970, while he was asleep in his family's farmhouse near Wilshire, Ohio. Four days later, a 14-day course of rabies vaccine was begun, but no antirabies serum was given (Table 1). Recovery was complete 6 months after the onset of symptoms.

The physicians (Hattwick and others, 1972) suggested that the rabies strain in this case may have been less virulent for humans than other strains, however that hypothesis was not pursued. Rabies variants from big brown bats have been shown to possess extremely different abilities to cause infection in animals (Bell and others, 1962; Constantine and others, 1968b), and geographically distinct rabies variants from this species are known in the United States (De Mattos, C.C. and others, 2001). For example, a bat identified as a big brown bat transmitted lethal rabies by bite to a woman in Maryland (Barnhart and others, 1976), but the rabies variant proved to be associated with the tricolored bat (Messenger and others, 2002). Alternately, an unidentified bat transmitted lethal rabies by bite to a man in Washington in 1997, and the rabies variant was identified as originating from a big brown bat (Geyer and others, 1997).

\section{Case history 1.}

\section{Day of} symptoms

1 Neck pain developed 2 days following the vaccine series (60 days after the victim was bitten by the bat).

5 High fever, appetite loss, vomiting, and dizziness, but alert and cooperative.

11 Pain in head and limbs, became lethargic, writing and walking were difficult.

13 Speech problems, uncooperative and bizarre behavior, bit and chewed on his saliva collection tube, weakness, partial paralysis, and seizures of the left side of the face and left limbs.

15 Coma, heart rhythm irregularities, and seizures. Aggressive treatment continued to prevent oxygen deprivation and intracranial hypertension. Excess cerebrospinal fluid removed from within the brain.

22

Coma ended and recovery began. 


\section{Case 2}

A more recent case of survival also involved a bat, but the species is unknown. In October 2004, in Fond du Lac, Wisconsin, a 15-year-old girl was bitten on her left index finger by a bat that she picked up and released outside after it had fallen from flight while it was inside a church. Nobody considered a potential rabies danger, thus rabies prophylaxis was not administered. The first symptoms appeared about 1 month later, and the patient was discharged from the hospital 80 days following the onset of symptoms (Table 2). Rehabilitation following release from the hospital contributed to this success story. A tutor helped the victim finish her sophomore year of high school so that she could rejoin her classmates in the fall. Physical therapy helped her to overcome speech problems, weakness in her left hand and foot, and abnormal movements in her arms and hands. The victim entered college as an 18-year-old freshman in the fall of 2007. She regrets that none of the 10 other rabies patients subsequently administered the same or similar treatment survived, but she continues her life with energy and enthusiasm. She is an aspiring wildlife conservationist, and she still loves animals, including bats.

\section{Case history 2.}

Day of
symptoms Symptoms/treatment

1 Fatigue, tingling, and numbness of the left hand about 1 month after the victim was bitten by a bat.

3 Unsteadiness, double vision, nausea, and vomiting, but no fever.

5 Fever of $101.8^{\circ} \mathrm{F}\left(38.8^{\circ} \mathrm{C}\right)$, slurred speech, involuntary eye movements, and tremors of the left arm.

6 Bat bite revealed, patient transferred to the Medical College of Wisconsin with a fever of $100.8^{\circ} \mathrm{F}\left(38.2^{\circ} \mathrm{C}\right)$, muscular twitching, incoordination, difficulty speaking, tremors in the left arm, dulled alertness, and hypersalivation. A tracheal breathing tube was installed. Because rabies signs had already developed, rabies vaccine or antirabies serum were not administered.

7 to 34 Partial paralysis and numbness due to sensory nerve dysfunctions. Extensive supportive treatment administered, including mechanical breathing, heart monitoring and treatment, intracranial hypertension control, antiviral drugs, and a drug-induced coma permitting the patient's rabies antibodies to increase and destroy the virus. After 7 days of coma, sedation medications were discontinued, and the patient became increasingly alert.

35 Patient removed from isolation and started on a rehabilitation program.

80 Patient discharged to her home.

\section{Coma and Intervention}

Although both human rabies survivors experienced coma, a natural and often terminal development in clinical rabies, the medical personnel of the first case merely acknowledged its existence whereas those in the second case induced coma with drugs. The latter authors (Willoughby, Jr., and others, 2005) said it was not clear if the induced coma played a role in the victim's recovery, but they recommended that their updated protocol and future updates (Medical College of Wisconsin, 2007) be followed in the treatment of subsequent patients. A focus for consideration is control of the patient's body temperature. 
Table 5. Human nonrabies lyssaviral infections reported in Africa, Asia, Australia, and Europe.

[ABL, Australian bat lyssavirus; EBL, European bat lyssavirus]

\begin{tabular}{|c|c|c|c|c|c|}
\hline Location & Year & $\begin{array}{l}\text { Source of } \\
\text { infection }^{1}\end{array}$ & $\begin{array}{c}\text { Number of } \\
\text { human cases }\end{array}$ & $\begin{array}{l}\text { Lyssavirus } \\
\text { species }\end{array}$ & Reference \\
\hline Australia & 1996 & Bat & 1 & $\mathrm{ABL}$ & Allworth and others, 1996. \\
\hline Australia & 1997 & Bat & 1 & $\mathrm{ABL}$ & Hanna and others, 2000. \\
\hline China & 2002 & Bat & 1 & Rabies-like $^{2}$ & Tang and others, 2005. \\
\hline Finland & 1985 & Bat & 1 & EBL-2 & Lumio and others, 1986. \\
\hline India & 1954 & Bat & 1 & Rabies-like $^{2}$ & Veeraraghavan, 1955. \\
\hline Kenya & 2007 & Bat & 1 & Duvenhage & van Thiel and others, 2008. \\
\hline Nigeria & 1968 & Unknown & 1 & Mokola & Familusi and others, 1972. \\
\hline Nigeria & 1971 & Unknown & 1 & Mokola & Familusi and Moore, 1972. \\
\hline Russia & 1985 & Bat & 1 & EBL-1 & Botvinkin and others, 2005. \\
\hline Scotland & 2002 & Bat & 1 & EBL-2 & Fooks and others, 2002. \\
\hline South Africa & 1970 & Bat & 1 & Duvenhage & Meredith and others, 1971. \\
\hline South Africa & 2006 & Bat & 1 & Duvenhage & Paweska and others, 2006. \\
\hline Ukraine & 1977 & Bat & 1 & Rabies-like $^{2}$ & Botvinkin and others, 2005. \\
\hline Ukraine & 2002 & Bat & 1 & Rabies-like $^{2}$ & Botvinkin and others, 2005. \\
\hline
\end{tabular}

${ }^{1}$ Bat species not reported.

${ }^{2}$ Untyped lyssaviruses causing rabies-like clinical signs.

\section{Bat Infections}

Studies of rabies in North American insect-eating bats reveal that incubation periods can be from 21 days to at least 209 days, and the duration of the disease can last from less than 1 day to 20 days. Most important, however, is the knowledge that individual bats have transmitted the virus by bite as early as 12 days before the appearance of clinical signs and 24 days before the death of the bat (Constantine, 1994). In either situation, a bitten person could develop clinical disease or be dead of rabies before clinical signs appear in the biting bat, a sobering prospect for persons who prefer to spare the life of a biting bat. Worse yet, if the bat becomes chilled, and thus lethargic or torpid, all of these periods become extended. For example, some bats are known to awaken from hibernation in spring, whereupon they resume development of rabies infection that has been placed on hold all winter (Constantine, 1967a; Box 4).

Paralytic rather than furious rabies appears to be characteristic of rabies in most infected bats, but there are disturbing exceptions. Infected insectivorous bats display neither external nor internal gross lesions nor clinical signs specific enough to permit a diagnosis prior to laboratory tests performed on brain tissue. They may display a variety of nonspecific clinical signs that change as the disease progresses or in response to environmental influences. Basically the bat may be expected to suffer nervous system disorders that make it overly responsive to sensory stimuli, such as touch, and that elicit retaliatory bites, tremors, and perhaps wing flapping. However, these responses are not diagnostic, because the approach of persons or animals can elicit similar behavior in healthy bats. Progressive paralysis of infected bats can increase irritability and biting of nearby objects. Such biting may also be used as an aid in crawling or climbing as paralysis disrupts coordination. Developing paralysis can oblige flying bats to alight on any elevated object, even a standing person, rather than land on the ground. Thus, bats found in unusual places may be infected. Flight problems decrease the bat's ability or efforts to secure food and water, leading to attendant weight loss and dehydration; captive bats simply cease to eat. If an infected bat does not fall to earth during flight, it may finally die in its shelter. In either situ- 
Table 6. Examples of incubation periods and times to death relating to human mortalities from bat-associated lyssavirus exposure.

[See appendix E for more detailed descriptions of the nine cases below]

\begin{tabular}{|c|c|c|c|c|}
\hline Case $^{1}$ & $\begin{array}{l}\text { Exposure } \\
\text { location }\end{array}$ & $\begin{array}{l}\text { Day of onset of } \\
\text { symptoms after } \\
\text { exposure }\end{array}$ & $\begin{array}{l}\text { Day of death } \\
\text { following onset } \\
\text { of symptons }\end{array}$ & Comments \\
\hline 2 & North America & 16 days & 9 & Victim bitten on forearm when bat picked up from ground. \\
\hline 4 & North America & 26 days & 12 & $\begin{array}{l}\text { Victim bitten on finger when bat was rescued from attack by dogs; dogs } \\
\text { potentially exposed. }\end{array}$ \\
\hline 5 & North America & 21 days & 7 & $\begin{array}{l}\text { Victim bitten on ear while sleeping; bite awoke victim, cat ate bat; cat } \\
\text { potentially exposed. }\end{array}$ \\
\hline 8 & India & About 11 weeks & ${ }^{2} 5$ & Victim bitten on forearm when bat was picked up from ground. \\
\hline 9 & Australia & Unknown & 16 & Victim cared for fruit bats. \\
\hline
\end{tabular}

${ }^{1}$ Case 1, Hurst and Pawan, 1932; Case 2, Sulkin and Greve, 1954; Case 3, Irons and others., 1957; Case 4, Humphrey and others, 1960; Case 5, Humphrey and others, 1960; Case 6, Lumio and others, 1986; Case 7, Meredith and others, 1971; Case 8, Veeraraghavan, 1955; Case 9, Allworth and others, 1996.

${ }^{2}$ May be longer, because the day of the onset of symptoms was not recorded.

ation, lack of activity can result in lethargy and consequent life extension before death (Constantine, 1967a; Sadler and Enright, 1959).

Rabies in experimentally infected vampire bats resembles the previously described infections in insect-eating bats in reference to the clinical disease, incubation period, illness period, and periods when virus can be detected in saliva (Moreno and Baer, 1980). This contrasts with early reports that vampire bats could be healthy carriers and excretors of rabies virus in saliva (Torres and de Queiroz Lima, 1935; Pawan, 1936). However, those early investigators may have mistaken as rabies one of a number of other viruses that can chronically infect bat salivary glands (Constantine, 1970; Constantine, 1988b). Another important characteristic of vampire bats is that, unlike most temperate zone bats, the tropical vampire bats are not physiologically able to lower their body temperatures to become lethargic or dormant, which would defer viral disease development (Lyman and Wimsatt, 1966).

Most infective bites from insectivorous bats are inflicted in a manner similar to bites inflicted by healthy bats for self-defense, such as when a bat is caught by a person or an animal. Rarely, however, some rabid bats, including insect eaters, are known to attack people, most often during daytime. Furious daytime attacks on people and animals by rabid common vampire bats have long been known during outbreaks in Latin America (Haupt and Rehaag, 1921; Torres and de Queiroz Lima, 1935; Pawan, 1936). Noise produced by or associated with the victim evidently can precipitate attacks (Constantine, unpub. data). Such attacks, like one experienced by the author, are known to be direct and quick, unlike the erratic flight of bats in pursuit of insects. Similarly, lyssavirus-infected black flying foxes of Australia are known to attack other bats repeatedly (Mackenzie, 1999). Unprovoked attacks by bats are clearly suggestive of rabies, but they are difficult to differentiate from events described by frightened people who think they are under attack by healthy bats that, in reality, are in pursuit of nearby flying insects.

Human perceptions of abnormal behavior by bats are not always correct and often result in healthy bats being mistaken as ill. Rather than being infected, the bats may be lethargic or dormant when at rest in a cool place. In addition, young bats may not yet be able to fly, or bats injured from cat attacks or other causes may appear partially paralyzed. Species that take shelter in the soft foliage of trees, such as hoary bats, sometimes are attacked by birds and fall to earth, where their tender wings suffer abrasions. These abrasions may cause the bats to react with a hissing sound and to extend their wings and thrash about in an effort to become airborne. This behavior occurs whether or not the bat is infected with rabies. 


\section{Seasonal Bat Behavior and Disease Transmission}

Most North American bat species live in temperate zones and are heterothermous, in that when a bat is inactive or sleeping its body temperature corresponds to that of the environment, similar to what is observed in cold-blooded (poikilothermous) reptiles and amphibians. When a heterothermous bat is active, however, its body temperature is regulated to a uniform warm level like that of most warm-blooded (homoiothermous) mammals and birds. Thus, when the environmental temperature decreases, heterothermous bats become cold and eventually lethargic or dormant when at rest, similar to a hibernating state that results in conservation of energy. Their flying insect food responds similarly to cold weather and does not fly. Many of these bats, the longlegged myotis for example, hibernate in winter, whereas others migrate to warm areas. Because most North American bat species either migrate to warmer climates or are inactive in cooler areas during cooler months, bat rabies similarly disappears during the winter. Accordingly, cases of bat rabies in the USA routinely start appearing in spring, increase until early fall, and decrease thereafter. North America's seasonal cycle of bat rabies has been repeated in part and with similar results in Latin America, Europe, Asia, Africa, and Australia, but seasonal patterns are less pronounced toward the equator.
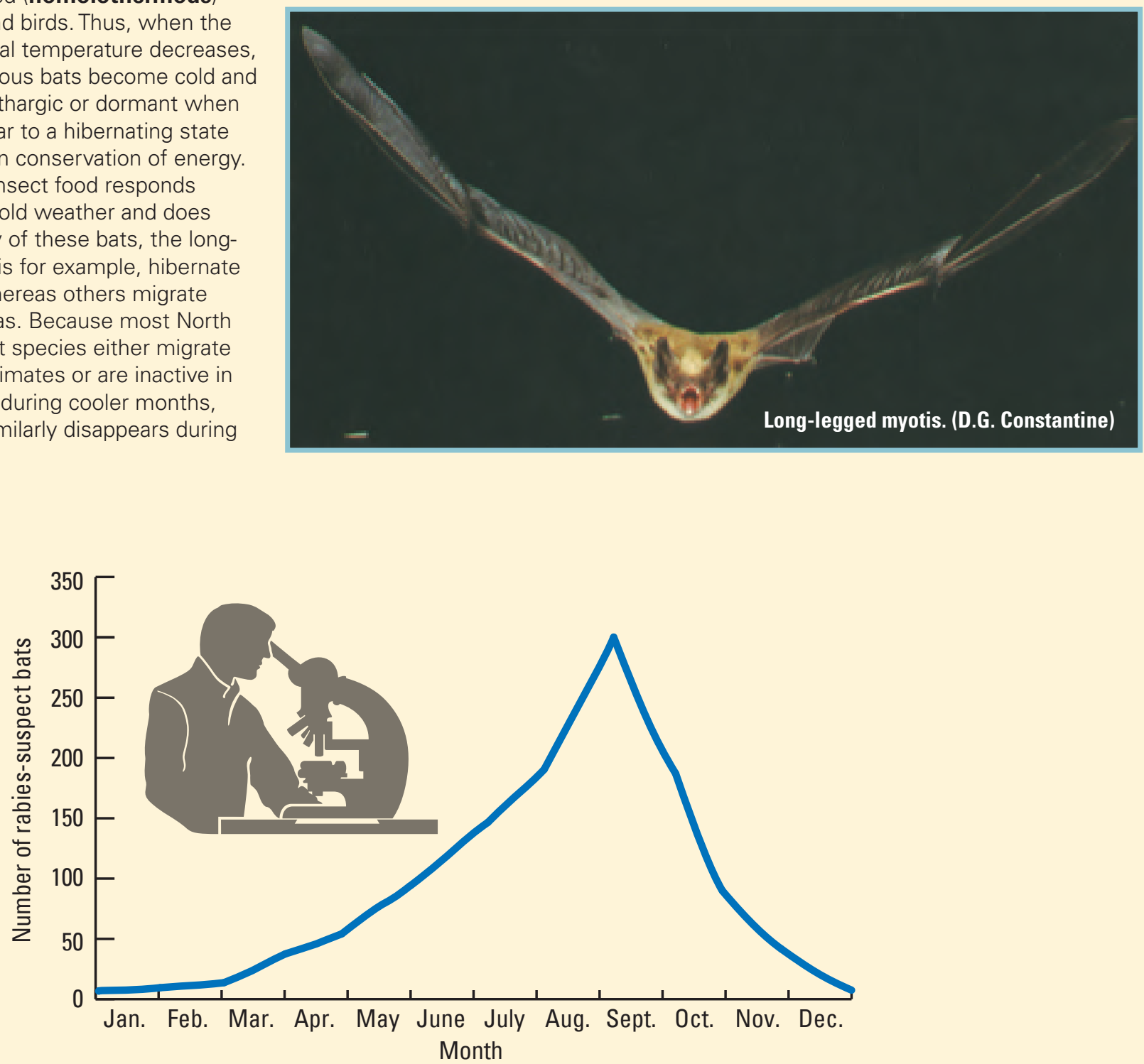

Submissions of bats suspected of having rabies, by month (reproduced from Blanton and others, 2007). 


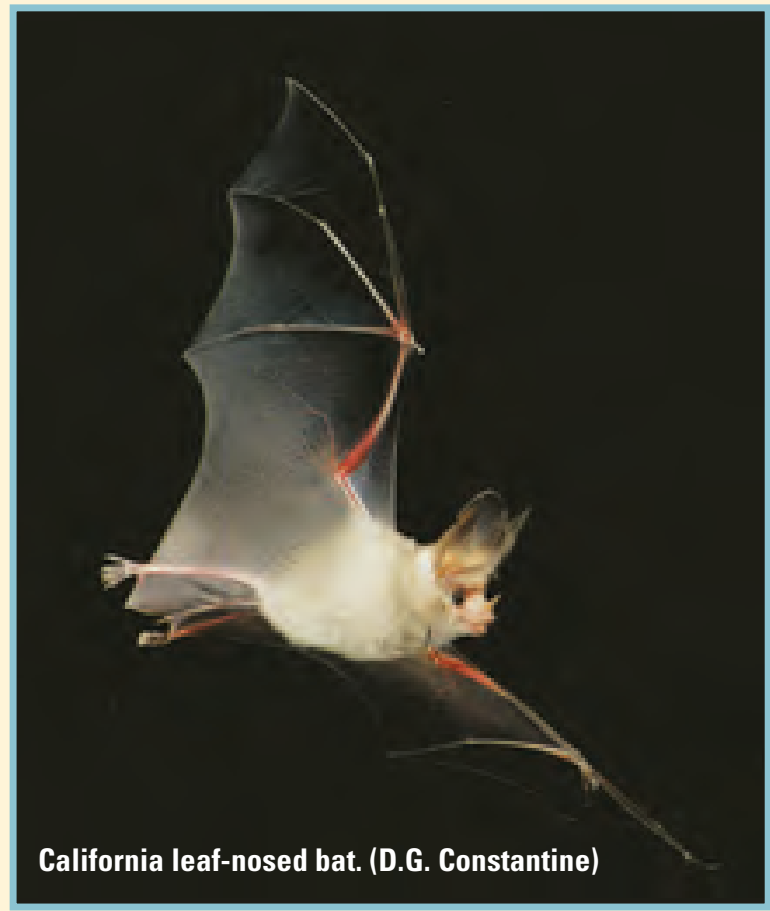

A smaller number of temperate North American bat species are full-time homoiothermous mammals. These bats cannot hibernate and must remain in a warm environment at all times. The California leafnosed bat, whose warm geographic range extends from Mexico into southern California and Arizona, does not migrate southward in winter and often inhabits geothermally warmed mine tunnels or caves. It selects warmer sites for shelter during winter, often within the same underground lair, and it flies outside to capture its insect prey as the weather allows.

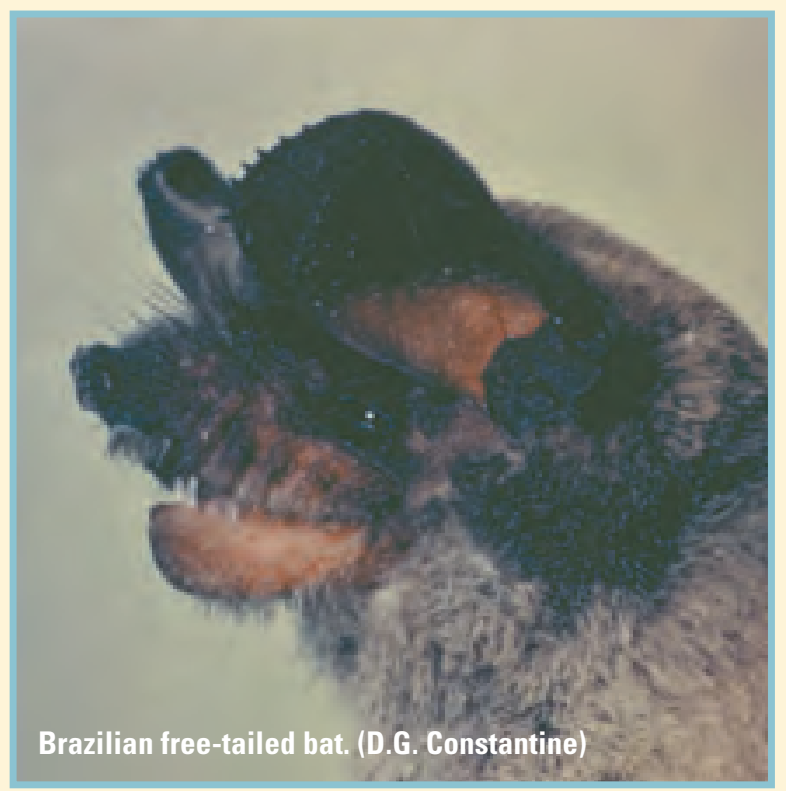

The Brazilian free-tailed bat, found in warm parts of North and South America, is intermediate between the homoiothermous and heterothermous bats. Although its body temperature decreases if it is inactive during short cold periods, it cannot undergo true prolonged hibernation. Instead, it migrates to relatively warm areas for winter, where the bats and their flying insect food both remain active. 


\section{Infections in Other Species}

In addition to direct exposures of humans to rabid bats, other animals, principally carnivores, may become infected or contaminated by rabid bats and consequently become additional sources for infection (Table 7). Experiments have demonstrated that domestic and wild carnivores are among the species susceptible to rabies variants of North American insectivorous bat origin, although variants differ in their degrees of infectivity for various carnivore species (Constantine, 1966a; Constantine, 1966b; Constantine, 1966c; Constantine and Woodall, 1966; Constantine, 1967a; Constantine, 1967b; Constantine and others, 1988a; Constantine and others, 1988b). Laboratory mice have been experimentally infected by bites of North American insectivorous bats (Bell and others, 1962). In addition, in 2006 following a public exhibition attended by approximately 150,000 people, a horse was

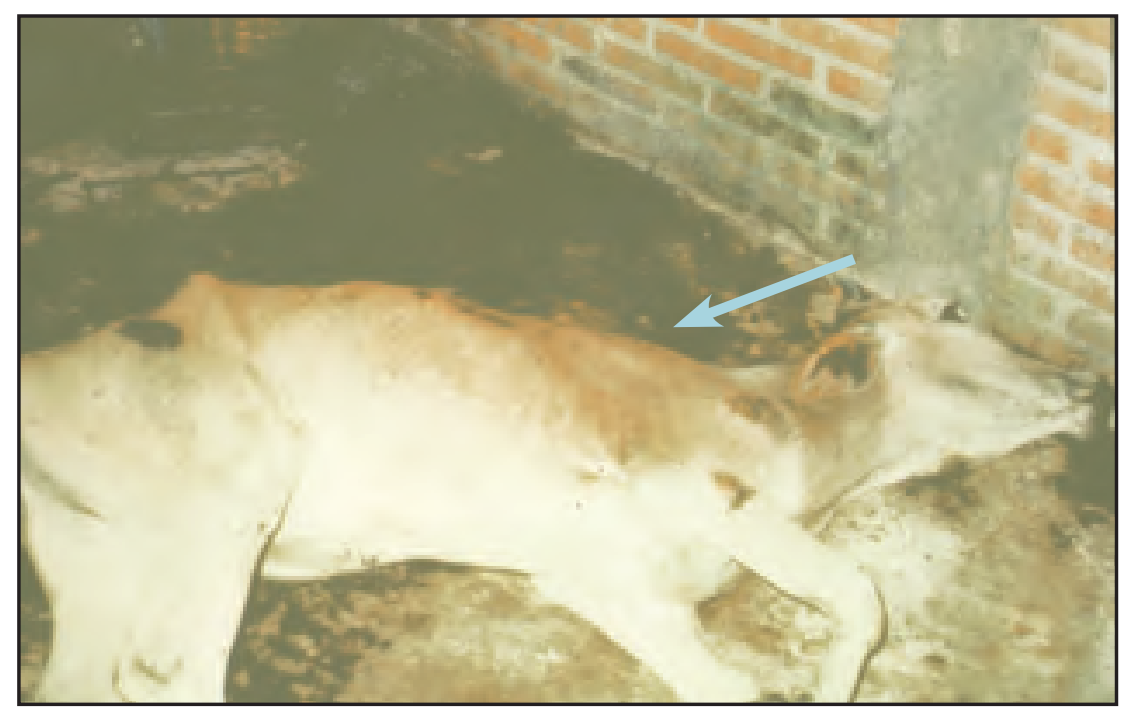

Figure 7. Circular pattern of earth excavation (dark area of ground behind calf (indicated by an arrow) resulting from confined body movement associated with posterior paralysis in a rabies-infected Zebu. (G.C. Mitchell)

diagnosed postmortem to have been infected with a rabies variant associated with big brown bats (Blanton and others, 2007). As a result, a health alert was issued by the state health department and 53 people who had attended the exhibition were consulted about potential rabies exposure. Some carnivores and other species are also known to be susceptible to other lyssaviruses (Table 1).

Vampire bat-transmitted rabies can kill and decimate herds of cattle as well as destroy horses, mules, donkeys, burros, goats, sheep, pigs, dogs, and poultry. Poultry, however, often soon die from exsanguination rather than rabies (Greenhall, 1988). After an incubation period of about 1 to 2 months, the disease kills cattle within several days to a week. Initially the animal is restless, perhaps excitable, and loses its appetite. The next day, its rear legs tremble and are uncoordinated due to developing paralysis, and it salivates profusely because of difficulty in swallowing. Some animals, especially Zebu cattle, may charge people, but the disease is primarily paralytic rather than furious. By the third day the animal is constipated, eventually falls onto its side, and cannot rise. On about the fourth day, posterior paralysis is complete, but attempted running with the forelegs can result in circular movement and consequent circular earth excavation (Fig. 7). Death follows in the next day or two (Baer, 1991).

Table 7. Examples of nonbat species infected by rabid bats.

\begin{tabular}{|c|c|c|c|}
\hline Cats & Occasional & Natural and laboratory infection & Increasing problem, presumably by bat bite or bat ingestion. \\
\hline Foxes & Rare & Natural and laboratory infection & $\begin{array}{l}\text { By bat bite, bat ingestion, or aerosols in congested free-tailed } \\
\text { bat caves. }\end{array}$ \\
\hline Skunks & Rare & Natural and laboratory infection & Presumably by bat bite or bat ingestion. \\
\hline Laboratory mice & Only in laboratory & Laboratory infection & By bat bite. \\
\hline
\end{tabular}




\section{Obtaining a Diagnosis}

A bat that is suspected of being infected with a lyssavirus must be euthanized and its brain tested in a laboratory to obtain a diagnosis. Standard tests for rabies virus suffice for lyssaviruses known to exist in the Americas or Australia, but special tests at regional disease diagnostic laboratories may be necessary to identify lyssaviruses found in Europe, Asia, Africa (Table 1), and perhaps elsewhere.

Because of the consequences for a human infection, the handling of bats merits precautionary measures. Local health departments generally provide directions to the public regarding submission of bats for laboratory diagnosis. Heavy leather work gloves prevent bites from most live insectivorous bats, and rubber gloves prevent skin contamination from the saliva or tissue fluids of dead bats. The bats often will be retrieved by animal control personnel. Dead bats should be double bagged and kept cold or frozen, even if they are decomposed or partially eaten. It is important to keep the dead bats cold or frozen to prevent further decomposition that may render test results unreliable, which would force medical personnel to decide that the bat was infected and to initiate appropriate lifesaving precautions for individuals known to have been exposed to the bat.

Complete histories that accompany submitted bats facilitate the rapid notification of persons-at-risk, the initiation of timely lifesaving medical management, and disease management involving relevant pets. Pertinent information often is not sought until after the bat has been determined to have been infected, thus causing the delay of lifesaving measures while information is obtained. Histories are most informative when they reconstruct the trail of events since the bat was first observed, including the kinds of known and potential exposures (bites, scratches, saliva, tissue fluids, etc); dates; places; the names, addresses, and telephone numbers of associated persons and animal owners; and known as well as potential pet or other animal contacts.

\section{Disease Ecology}

The ecology of bat rabies and other lyssavirus infections is closely associated with bat ecology, including bat feeding strategies (Box 5) and the dynamics of infection within various bat species. Thus, those factors provide the focus for this section on Disease Ecology, along with differences in global virus transmission in relation to vampire bats or to other bats. Consideration is also given to the environmental persistence of lyssaviruses and their hosts.

\section{Bat Activity and Disease Patterns}

Bat lyssavirus is evident where and when bats are present and physiologically active (rather than in hibernation), which coincides with the availability of bat food. Most information on this subject is derived from studies in the temperate and tropical areas of America, with evidence of comparable patterns in these zones globally. Bats are present and active in temperate areas during warm seasons, when their flying insect food is available, and correspondingly, bat infection is also evident at these times. As the cold season approaches, evidence of both insects and bats decreases and eventually disappears, as do cases of bat lyssavirus. During this period, some bat species migrate to warmer areas, where insects are available. Other species retire to cold sites like caves to hibernate instead of migrating (Fig. 8). In contrast, bat food, such as insects and fruit, is available during all seasons in tropical areas, and bats and bat infections may be evident continuously in those areas.

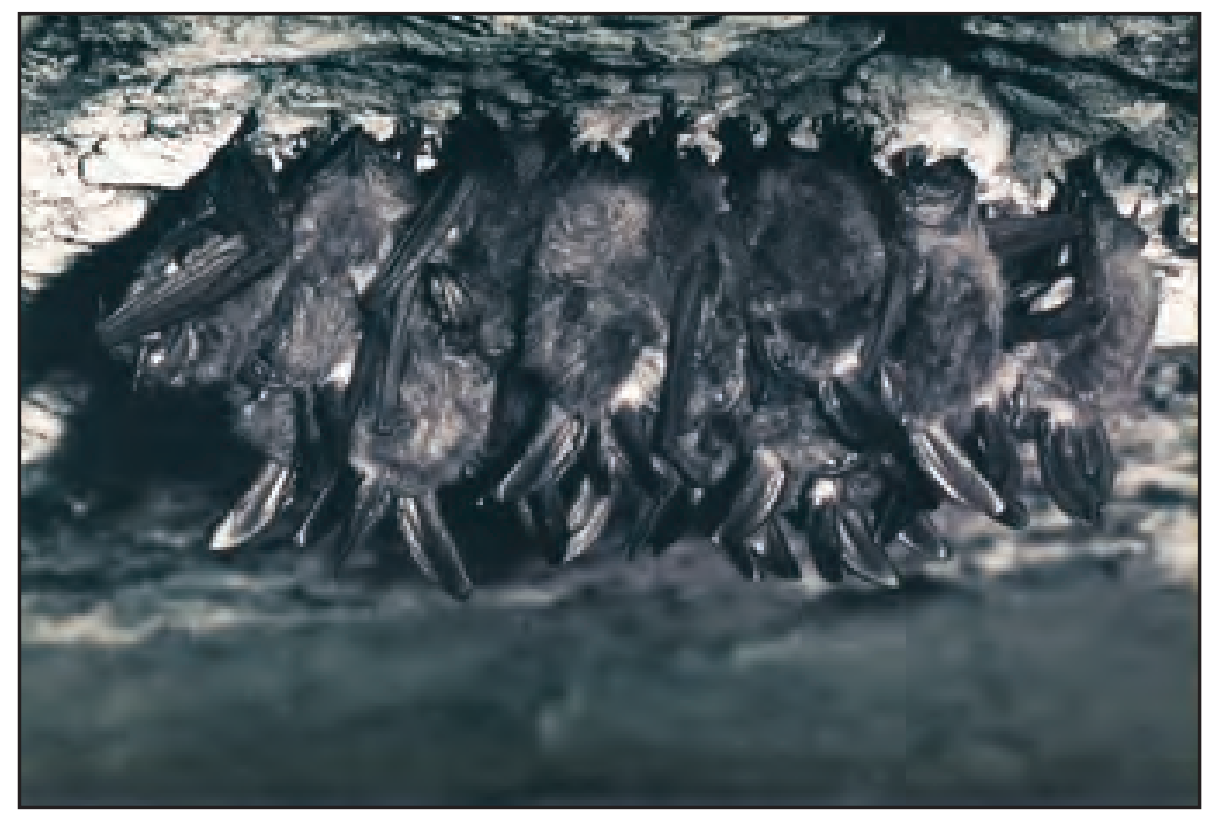

Figure 8. Townsend's big-eared bats awakening from hibernation. The ears of some bats are still folded beneath their folded wings, in typical hibernation position. (D.G. Constantine) 


\title{
Bats-Diverse Mammals with Diverse Diets
}

\begin{abstract}
Bats are distributed globally to the limits of tree growth and divided into 1,116 species (Simmons, 2005). Different groups or species of bats exhibit specialized dietary preferences. Bats in temperate zones are less numerous and diverse than those in tropical zones. Thus, while insectivorous bats are most common in temperate regions, the greater availability and variety of dietary items near the equator supports a diversity of food choices and food specializations among tropical bat species, a few of which are discussed below.
\end{abstract}

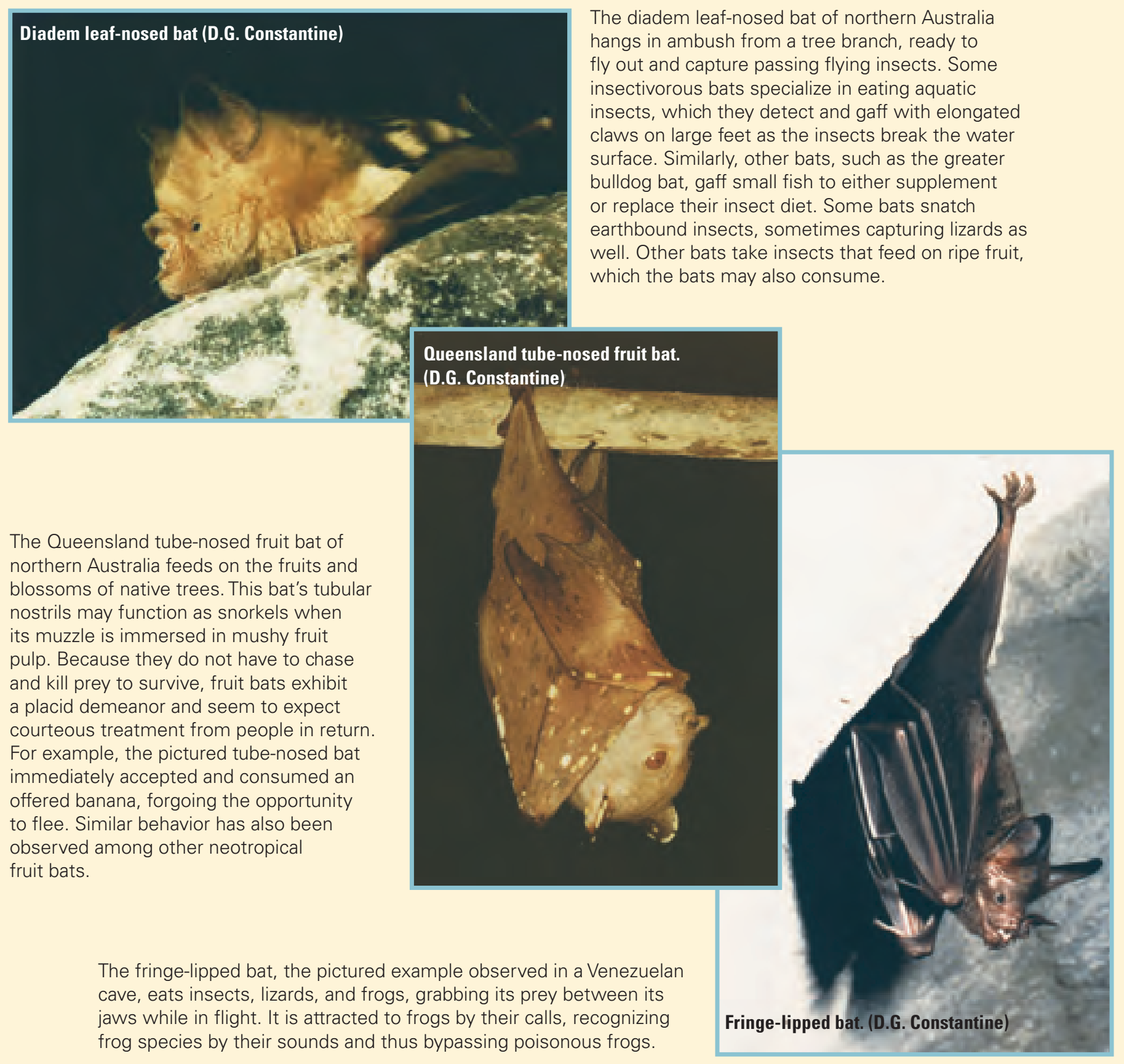




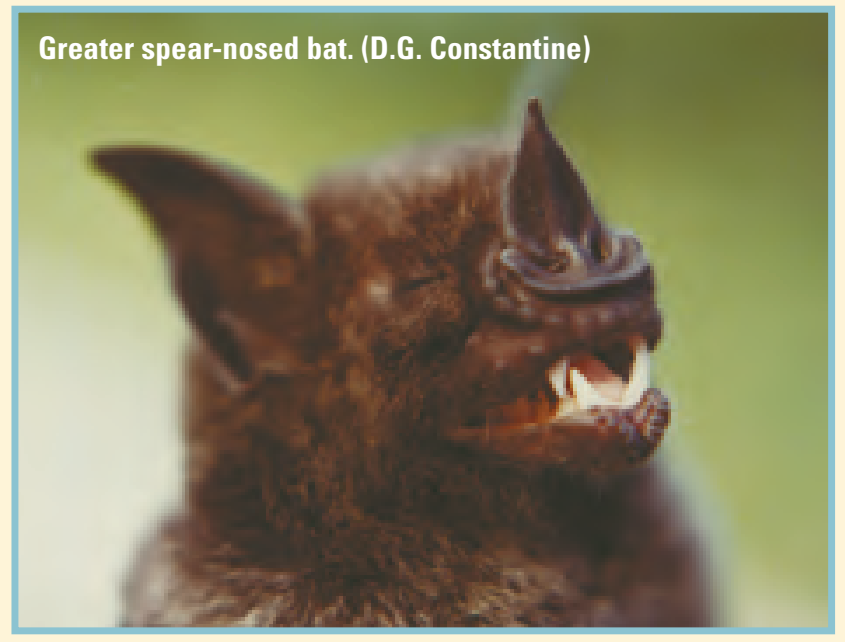

The greater spear-nosed bat is omnivorous, eating insects, smaller bats, mice, birds, and fruit. The pictured bat, netted in Trinidad, shared the author's dinner the day it was captured, eating filet mignon and fruit salad.

The common vampire bat, the pictured example captured in Trinidad, is sanguivorous and consumes only blood. Literally bloodthirsty, it will die if it does not feed for 3 nights. Fearless when under attack,

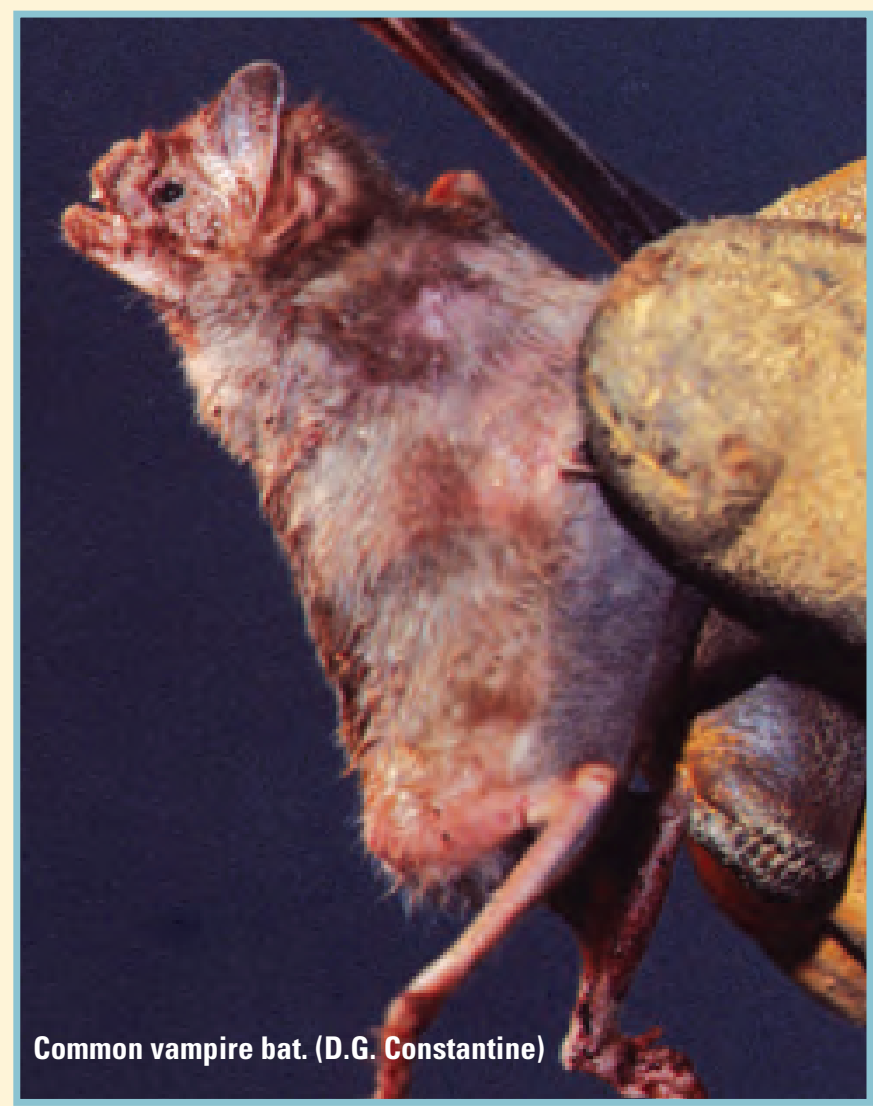

vampire bats deftly escape from potential predators, a reaction that can be unnerving to a human trying to outwit a single bat, to say nothing of an encounter with a dozen or more. Regardless of the size disparity, vampire bats view humans as a source of nourishment. The first vampire that the author observed was on all fours, with its wings folded to serve as forelegs, staring at him from a ledge near the ceiling of a Mexican cave and trying to determine its distance to the potential human prey by doing "push-ups" and moving its head from side-to-side, similar to an owl's head movements during hunting. Several nights later another vampire bat, caught in the author's harp trap (Constantine, 1958) as it tried to enter a calf pen in search of a meal, likewise stared at the author, calculating its distance to him from within its cage. The vampire bat's predatory nature shows courage, determination, and rapid responses when it must avoid retaliatory attacks, such as repeated kicks when it tries to obtain blood from the hind feet of cattle. Vampires are adept at avoiding kicks by jumping out of the way, only to swiftly return.

A vampire bat caged with a rat will relentlessly pursue the rat as prey and almost invariably triumph, even "boxing" the rat with its folded wings to ward off retaliatory charges. Similarly, when caged with a large snake intent on eating the bat, the vampire is capable of repeatedly avoiding strikes and persistently holding its course until able to obtain its blood meal from the nose of the seemingly hypnotized snake (Greenhall, 1988). Thus, the impression is fostered that the bat is endowed with the supernatural powers of the fictitious Dracula (Stoker, 1897). 
The most effective way to determine if infected bats exist in an area is to test clinically ill and dead bats. This type of surveillance for lyssavirus infections is often required for protection of the public health. Although the prevalence of infection among clinically ill bats varies from species to species in the USA, it averages 10 percent, which is similar to the 8 percent prevalence reported in Europe. To find at least one infected bat, one must test a minimum of 22,29 , or 44 clinically ill bats for statistically reliable results at confidence levels of 90, 95, or 99 percent, respectively (Constantine, 1994).

Studies of some bats indicate that they undergo population fluctuations in response to mortality caused by lyssavirus infection, similar to the occurrence of the infection in carnivores such as foxes and skunks (Constantine, unpub. data). Mortality decreases the population, and accordingly, evidence of subsequent disease until the population increases to a density that again supports lyssavirus transmission through increased frequency of contact. Increased rainfall can hasten population growth by providing greater plant growth to support the development of bat food, such as insects, and thus the greater survival of bats. Some migratory bats will forsake areas of drought for more suitable places. At the other extreme, however, atypically prolonged rainfall retards the flight of both insects and bats and is known to cause mass starvation of some bat species (Constantine, 1982a).

\section{Temperature and Rabies Virus Virulence}

Temperature can be critical in the manifestation or control of diseases, including rabies. The hypothermia of hibernation increases the resistance of an animal host to various viral, bacterial, and metazoan parasites. In many instances, disease is prevented or diminished. In other instances, disease development is deferred during hypothermia and resumes when the host awakens. In addition, viruses usually cannot replicate at higher temperatures, and fever in the infected host serves to depress viral development. However, certain highly pathogenic virus strains have adapted to this condition and are able to replicate at higher temperatures. Lower body temperatures may favor less virulent rabies virus strains. The seasonal differences in the body temperatures of heterothermic bats may account for some virulence differences observed among the rabies virus variants from different bat species (Constantine, 1967a; Constantine,1970).

\section{How Colonial Bats Avoid Extinction by Lyssaviruses}

It would seem that highly colonial animals, such as many bat species, would be eliminated quickly after a lyssavirus enters the population, but multimillion-bat colonies persist in the presence of the disease. Studies of rabies in huge populations of Brazilian free-tailed bats in caves of the southwestern USA and Mexico provide some insight into this question (Constantine and others, 1988a). In essence, maternal antibody provides a protective barrier or passive immunity against disease upon virus exposure within the colonies. Subsequent virus exposure then stimulates the immune system to provide protective antibody or acquired immunity for the long-term protection of exposed bats (Box 6).

\section{Paralytic and Furious Disease Courses}

The author's early experiences with bats and bat rabies in North America indicated that rabid bats experienced only the paralytic form of the disease without obvious aggressiveness or furiousness. For example, he and coworkers spent the equivalent of many years in and about caves occupied by millions of Brazilian free-tailed bats and were never attacked, although one of every 200 bats was infected (Fig. 9). In addition, none of the thousands of bats of other colonial bat species attacked under similar circumstances. Logic suggested that sufficient biting or other forms of transmission had occurred normally and frequently enough among these crowded animals to have rendered the furious form of rabies relatively superfluous and perhaps obsolete as a viral survival mechanism.

However, lyssavirus-infected bats do attack. Initial reports of attacks by flying rabid bats were limited to certain species that live as solitary individuals. These included the more diminutive of North American bats, primarily the canyon bat (Fig. 10), and, less often, the western small-footed myotis (Fig. 11) and the California myotis (Fig. 12) (Constantine, 1967a). It was suspected that deliberate attacks by these small solitary bats on conspecific bats had been retained as a necessary viral survival mechanism. Eventually, however, attacks on people by individual rabid bats of various species, including Brazilian free-tailed bats and other colonial bats, were documented. Fortunately, such attacks are rare events that are committed by individual rabid bats separated from colonies that otherwise would seem to dominate their interest. Thus, unwary investigators were likely spared attacks because they could not compete with the noisy bat colonies for the attention of any rabid bats primed for attack. 


\section{Immunity to Lyssaviruses in Colonial Bats}

Studies of rabies in huge populations of Brazilian free-tailed bats in caves of the southwestern USA and Mexico revealed that rabies infection is present in about 0.5 percent or 1 of every 200 of the mature bats (Constantine and others, 1968a). Disease transmission by infective saliva was possible from bites, licking of saliva into wounds or mucosal surfaces, or contamination by or inhalation of cave air charged with droplets of saliva expelled by the chattering bats (Constantine, 1967a; Constantine, 1967b). As many as 80 percent of the bats examined possessed recognizable blood serum antibodies against the virus. Colonial bats develop life-long immunity to rabies virus by two mechanisms. Unborn and suckling bats receive a temporarily effective dose of antibodies by way of the placenta and milk (passive immunity), but this immunity is typically lost 6 to 10 weeks following birth (Constantine and others, 1968a). Many young bats, while they are still temporarily immune, are also likely exposed to virus, which they resist by passive immunity, but against which they consequently developed long-lasting antibodies (active immunity). Such bats would be expected to respond to future viral exposures as if they were receiving booster doses of rabies vaccine. Young bats killed by rabies within the colonies were presumably produced by non-immune mothers. This scenario provides a mechanism for these populations to survive in the presence of rabies virus. The virus "immunizes" most of the population, but it still claims sufficient victims to maintain disease within the colony so that the virus persists.

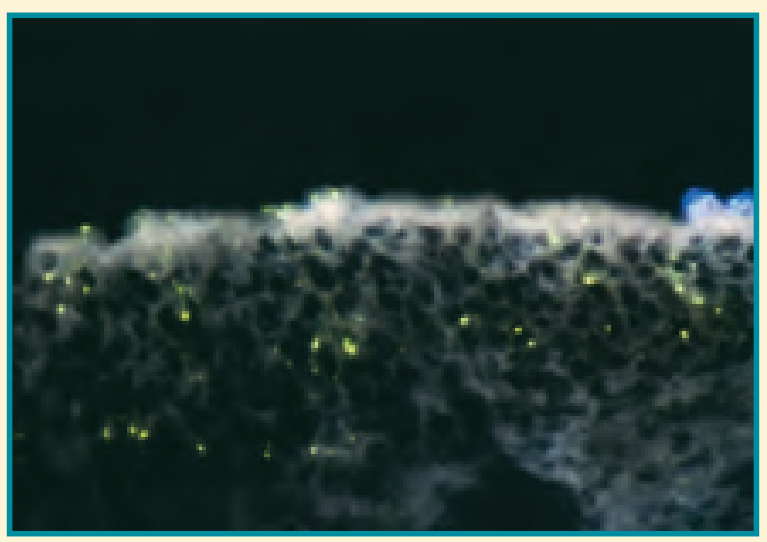

The nasal mucosa may be a site of rabies entry and exit from victims in some highly congested bat caves. This 2-micron section of nasal mucosa from a symptomatic, immature Brazilian free-tailed bat (Tadarida brasiliensis) from the Frio Cave, Uvalde County, Texas, was stained with fluorescent dye that indicates the presence of rabies antigen, shown by the apple green areas.

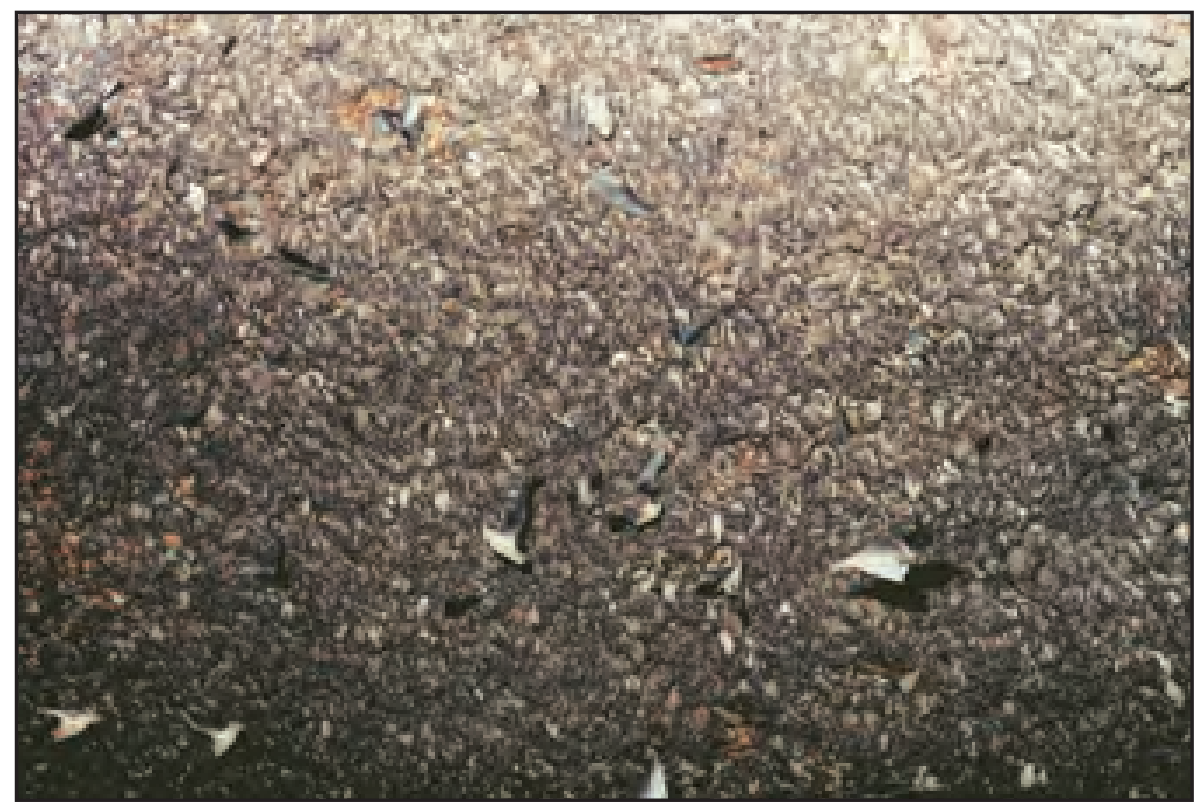

Figure 9. Brazilian free-tailed bats attempting to find roosting space among a dense colony of cohorts on a cave ceiling (bat density equals approximately 300 bats per square foot). (D.G. Constantine) 
Figure 10. Canyon bat in flight. (D.G. Constantine)

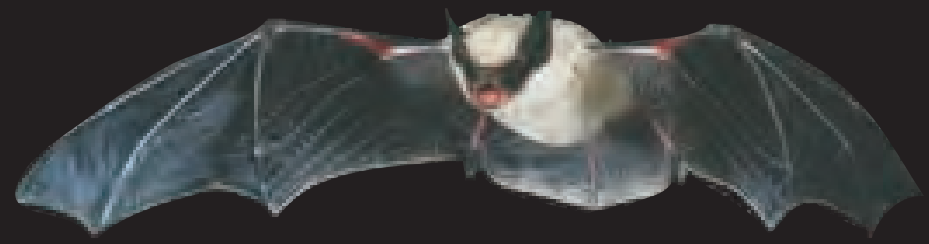

Figure 11. Western small-footed myotis bat in flight. (D.G. Constantine)

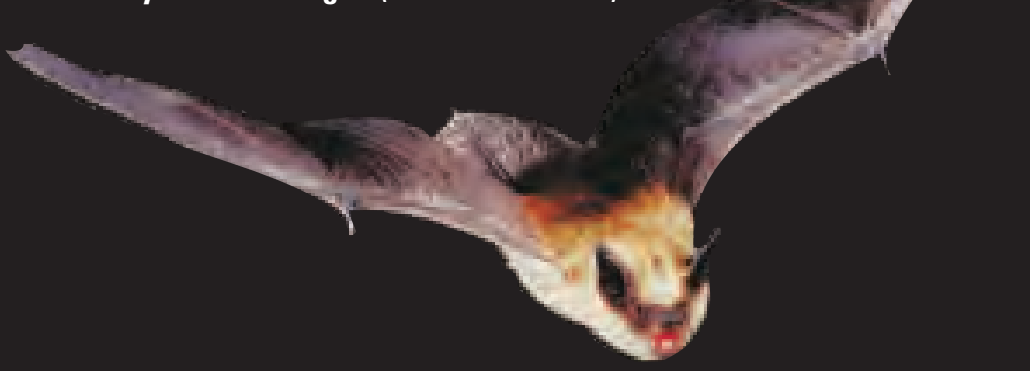

Figure 12. California myotis bat in flight. (D.G. Constantine)

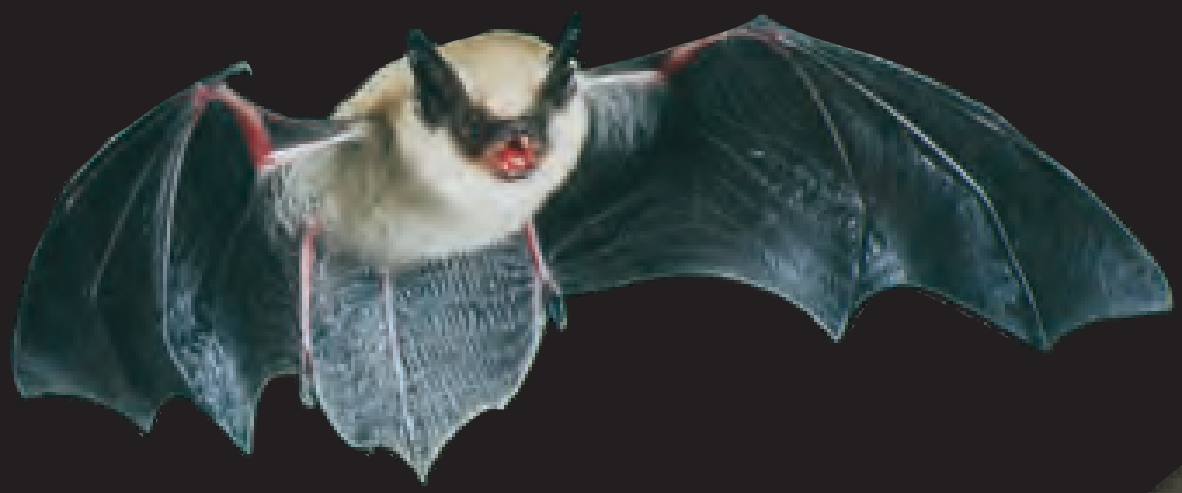

Figure 13. Big brown bat in flight. (D.G. Constantine) 


\section{Viral and Host Species Diversity}

Current information suggests that each species of lyssavirus may be divisible into several or more strains called variants. Each variant is maintained within populations of a particular reservoir host species to which it is adapted. Typically, these hosts are isolated by ecologic, anatomic, and social factors from other host species. Further isolation is afforded to viral variants harbored within sedentary, nonmigratory host species. Recent studies indicate that some sedentary reservoir host species populations are divisible into different DNA-identifiable host subpopulations that occupy different extensive, although often contiguous, geographic areas. Thus, these subpopulations provide conditions of isolation that favor the development of unique viral variants. For example, such a geographic correlation between nonmigratory big brown bat (Fig. 13) populations and the distributions of the rabies virus variants they maintain has been observed in the USA (De Mattos C.C. and others, 2001). The nonmigratory common vampire bat rabies virus is similarly divided into at least three geographically distinct variants (De Mattos, C.A. and others, 2001). In contrast, the Brazilian free-tailed bat, whose migratory habits conflict with population isolation and differentiation (McCracken and others, 1994), harbors fewer and less contrasting variants (Smith, 1996).

Although the association of a given virus variant with a particular animal host species can be useful for tracing the origin of infection in atypical victims, such as humans, it cannot rule out intermediate hosts. For example, cats that chew infected bats may subsequently transmit the virus to people, either promptly by mechanical transmission or perhaps later if the cat develops rabies. However, the relatively rabies-resistant cat may not become infected, eliminating it as a suspect intermediate host (Constantine, 1967a; Bell and Moore, 1971). Thus, these early studies indicated that rabies viruses recovered from various bat species differed in their abilities to infect or produce (or both) particular pathological responses in a given spectrum of wild carnivore or laboratory mammal species. These studies foreshadowed later serological methods followed by protein- and RNA-based analyses that now are used to delineate virus variants. The original discoveries of virus variants multiplied the challenge of defining the public health significance of bat rabies, but at the same time, they helped clarify it. Nonetheless, the challenge continues to grow by disclosures of rare-to-frequent transmission of variants from one host species to another, sometimes with serial transmission thereafter, as described below in the section on intraspecies and interspecies transmission. Such host interspecies transfer of virus raises the specter of potentially unwelcome consequences, such as a change from a predominantly paralytic disease to unabated furious disease and consequent attacks.

\section{Intraspecies and Interspecies Transmission of Bat Lyssaviral Variants}

Lyssaviral variants can be transmitted between bats of the same species (intraspecies) or among bats of different species (interspecies). Intraspecies transmission seems evident when infection with like variants is present in both mother and suckling bats in the absence of contact with other sources of virus. Such conditions usually prevail in multimillion aggregations of Brazilian free-tailed bats. Similarly, the northern yellow bat, a solitary species that takes shelter in tree foliage, has been found rabies infected with its litter of three rabies-infected suckling offspring (Schneider and others, 1957). Also a lactating eastern red bat and her litter of four were all rabies infected (Birney and Rising, 1967). Newborn bats might be infected by their mother as she severs the umbilical cord, by licking infective saliva onto mucosal surfaces, by bites, or by aerosol in some environments. Conspecific mature bats probably are infected by various similar methods as they crowd together in shelters or interact at feeding or drinking sites. However, more than one colonial species sometimes live in the same shelter, where single or multiple interlopers may crowd into another species' cluster (Figs. 14 and 15), possibly to maintain body heat, whereupon bites might be exchanged. Thus, interspecies transmission of virus seems a logical source of virus variant differentiation within the recipient species over time (Box 7).

Although lyssaviruses usually are transmitted by bite, alternate exposure routes include aerosols, ingestion, and by contamination of wounds or mucosal surfaces with infective saliva or tissues (Johnson, 1965; Constantine, 1988a). These viruses may survive through additional possible and probable transmission routes, including insects. Although Mokola lyssavirus has been shown to replicate in inoculated mosquitoes, biological transmission by arthropods of that or other lyssaviruses has not yet been demonstrated.

Mechanical transmission by arthropods however, seems likely in certain situations. Dermestid beetles and their larvae, for example, consume the tissues of live or dead rabid bats in huge cave colonies of Brazilian free-tailed bats (Fig. 16), and the author has demonstrated rabies virus on the exteriors of both life stages of beetles recovered from the skull cavities of bats (Constantine, unpub. data). Adult beetles and larvae seeking flesh to eat will attack living or dead mammals, including humans. In so doing, the contaminated insects may be able to mechanically transmit the virus. The abdominal contents of beetles that feed on bats are known to be consumed by assassin bugs, which routinely attack mammals, including humans, for blood meals. Such rabies-contaminated bugs may also be able to mechanically transmit virus in this manner. Various mites, hordes of which parasitize bats, include species that consume fluids available at the edges of mouths, eyes, or within the nostrils or ears of bats as well as of human visitors to bat caves. Thus, these feeding habits may provide opportunities for interspecies mechanical transmission of virus. 

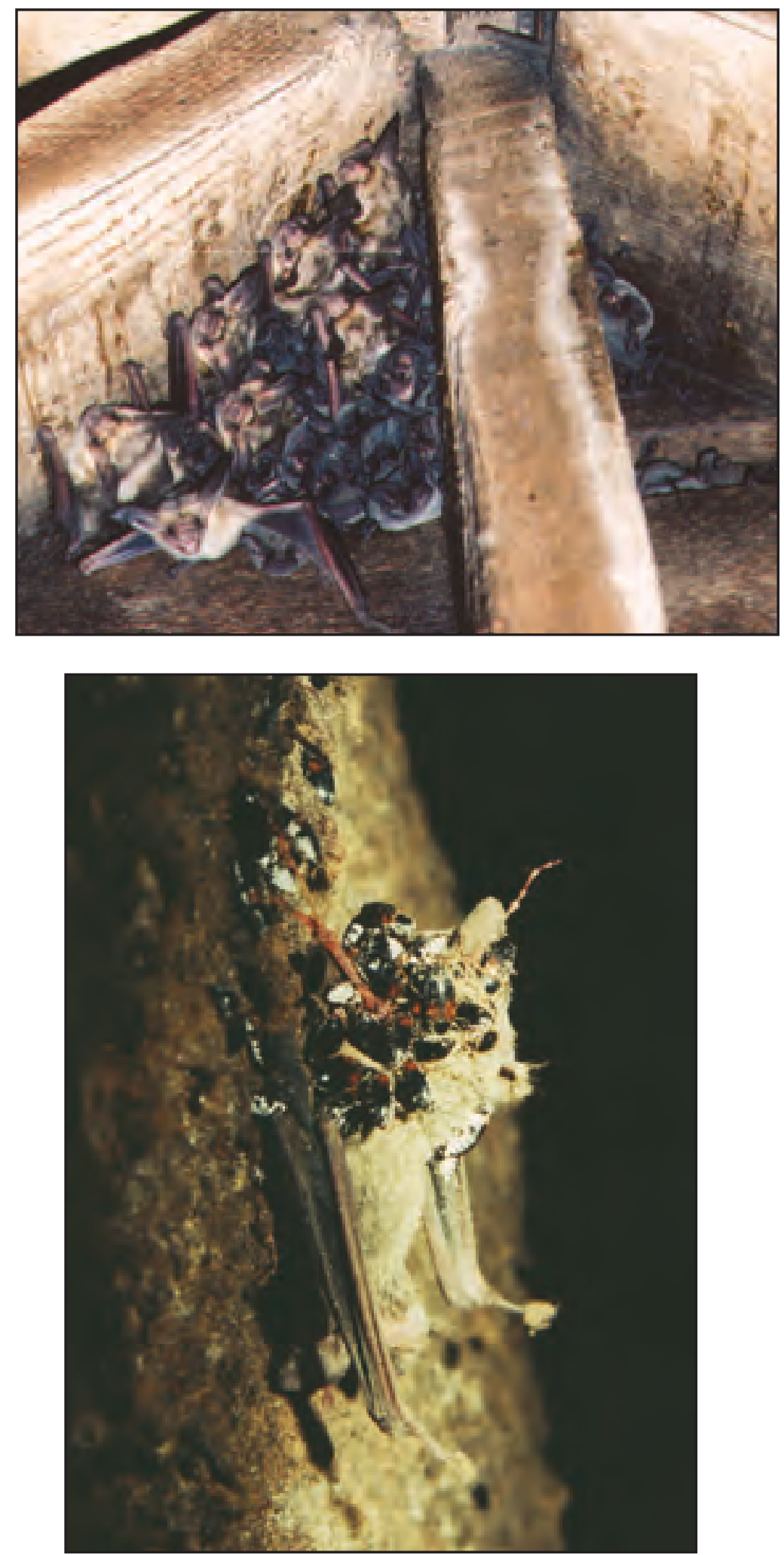

Figure 16. A dead Brazilian free-tailed bat being consumed by dermestid beetles commonly found in association with bat colonies. (D.G. Constantine)
Figure 14. A mixed group of pallid (light-colored) and Brazilian free-tailed (blue-grey) bats in an attic. (D.G. Constantine)

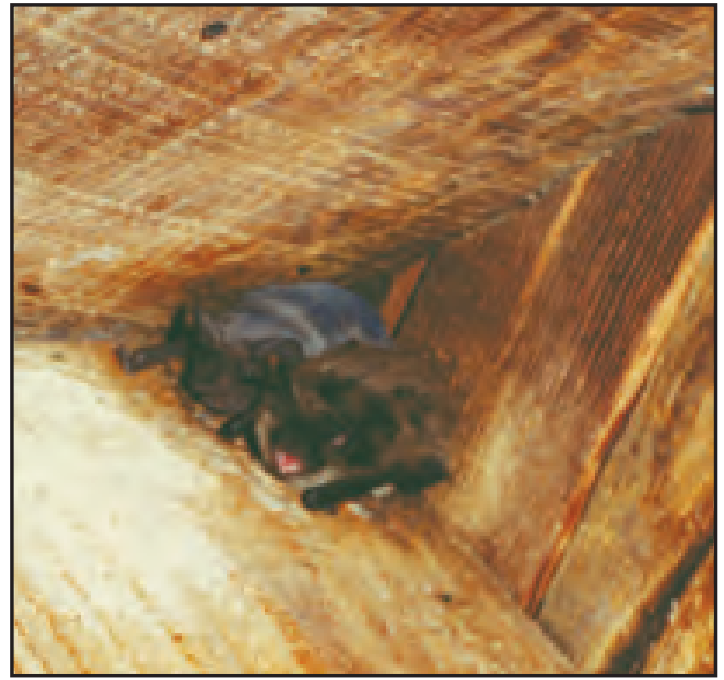

Figure 15. A Brazilian free-tailed bat (blue-grey) and a Yuma myotis bat (brown) cooperating to conserve body heat. (D.G. Constantine)

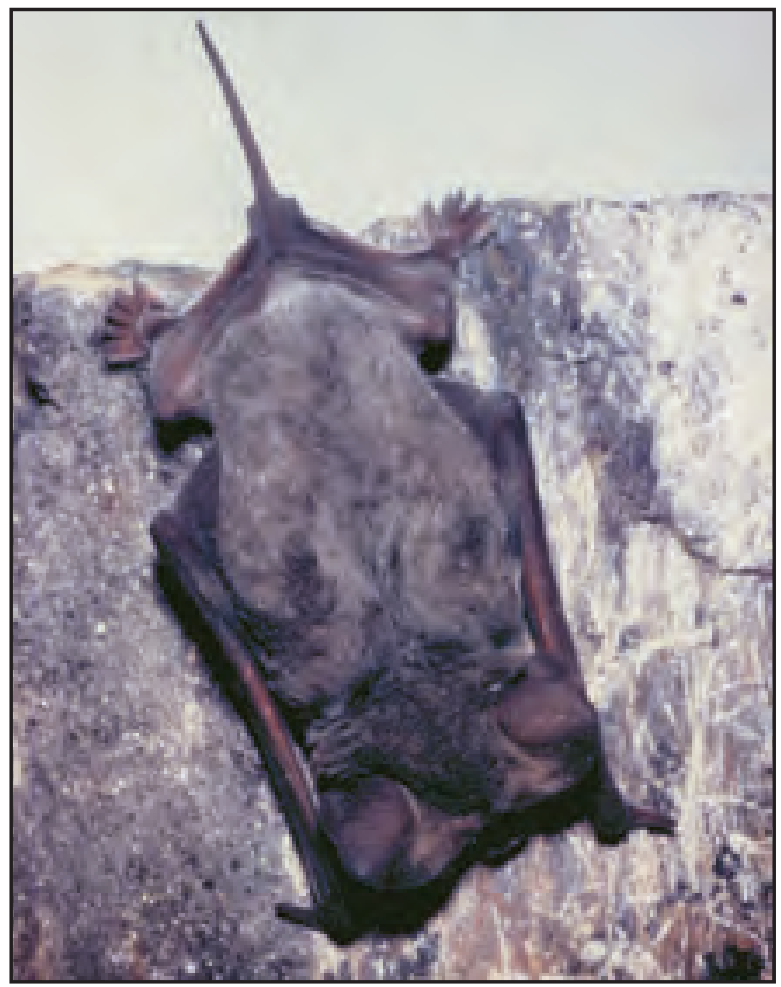

Figure 17. Brazilian free-tailed bat. (D.G. Constantine) 
Table 8. Examples of vampire bat rabies variants found in other species in Latin America.

\begin{tabular}{lcl}
\hline Country & Date & \multicolumn{1}{c}{ Findings } \\
\hline Brazil & $1998-2001$ & 22 of 23 dog and cat rabies cases tested (Kotait and others, 2001). \\
& 2000 & 32 of 53 non-vampire bat rabies cases tested, representing 16 different bat species (Silva, 2001). \\
& 2001 & A cat previously in contact with a bat developed rabies and infected its owner (Kotait and others, 2001). \\
Costa Rica & 2001 & An aggressive household cat bit two people who died of rabies of vampire bat origin (Badilla and others, 2003). \\
Mexico & $1999-2001$ & Fruit bat and dog (Vargas Pino, 2001; Velasco Villa and others, 2001). \\
& 2004 & Child bitten by cat (Tesora Cruz and others, 2006). \\
\hline
\end{tabular}

The development of methods to recognize and classify viral variants by their host species of origin has helped to retrospectively identify the infection source, such as a particular species of bat or carnivore, putatively responsible for infecting a human victim (Rupprecht and others, 1991; Smith, 1989). Recent reports based on these techniques also indicate that a large amount of interspecies lyssavirus transmission has occurred between mammal species, especially from vampire bats to other bats and carnivores.

\section{Latin America}

Vampire bat rabies virus has been isolated from other bats and from carnivores in Latin America (Table 8). These findings indicate direct transmission of rabies by vampire bats or by other bats that might be serially transmitting the vampire rabies variant. Moreover, where Brazilian rabies vaccination campaigns had brought urban canine and feline rabies under control, the finding of a vampire rabies variant instead of a canine rabies variant as the cause of recent rabies cases in dogs and cats (Table 8) indicates that the vampire bat variant is transmitted serially among pets.

Reports of interspecies transmission of rabies by bats other than vampires refer nearly exclusively to insectivorous species. In Chile, where five rabies virus variants were studied, the Brazilian free-tailed bat (Fig. 17) was considered to be the source of a variant found in one human, dogs, cats, cows, and a pig. A variant typical of Western red bats or other members of the genus Lasiurus was recovered from a red bat, three Brazilian free-tailed bats, and a dog. It was suspected that livestock were infected by dogs or cats that had acquired the infection by attacking grounded bats, but none of the identified variants closely resembled variants associated with vampire bats (De Mattos, C.A. and others, 2001; Favi and others, 2002).

\section{North America}

There have been 51 known or presumed bat-transmitted human rabies infections in the USA (Messenger and others,
2002; Krebs and others, 2003; Krebs and others, 2004; Blanton and others, 2006) and Canada (Dempster and others, 1972; Varughese, 1983; Webster and others, 1987; Krebs and others, 2001; Krebs and others, 2004) from 1951 to 2006.

Human cases were attributed to bat species based on bat carcass identification or prior association of rabies variants with a given bat species (Table 4). Bat carcasses were often unavailable for species identification and for comparison with identified virus variants. In cases where bat carcasses were available, tricolored bat virus variants were identified from a big brown bat, indicating interspecies transmission, and from a bat retrospectively identified by an untrained observer as an eastern red bat (Hardman and others, 1995). However, red bats and tricolored bats have similar pigment distribution in their wing membranes and could be confused with one another. In studies of rabies in Alaskan bats (Blanton and others, 2007), a little brown myotis was infected with a rabies variant associated with silver-haired bats, and a Keen's myotis was infected with a variant associated with eastern red bats. The frequent absence of a bat contact in the human victim's history also leaves open the possibility that an intermediate host, such as a cat that had chewed a rabid bat, might be the source of some human infections.

Transmission of rabies from bats to individual wild or domestic carnivores and livestock in the USA was implied in various earlier reports based on virus variant characteristics (Rupprecht and others, 1991). Notwithstanding the possibility of viral transmission by intermediate hosts, 28 animals (11 foxes, 1 skunk, 7 cats, 2 cows, 6 horses, and 1 sheep) were suspected of having been infected by 12 big brown bats, 8 eastern red bats, 2 Brazilian free-tailed bats, and 6 bats of undetermined species (Baer and Smith, 1991). A survey in Colorado designated a rabies variant identified from big brown bats as the infective agent in three skunks and one fox (De Mattos, C.C. and others, 2001). A study of rabies virus variants obtained from 19 skunks during a skunk rabies outbreak in Arizona indicated that those variants were nearly identical to a virus variant commonly found in big brown bats, the suspected source of the outbreak (Leslie and others, 2006). These results provide possible evidence of serial trans- 


\section{Bat Versus Bat-Interspecies Transmission of Bat Lyssaviruses}

In 1957, before rabies virus variants were known to exist, the author sought bat shelters in Mexico that were occupied by common vampire bats and migratory Brazilian free-tailed bats from the USA. The purpose of that inquiry was to explore the possibility that vampire bats might occasionally attack and drink the blood of insectivorous bats, as had been observed among captive bats. Such behavior would facilitate virus transmission from infected vampire bats. Alternatively, vampires might be infected by saliva-contaminated air in some free-tailed bat cave shelters or by retaliatory bites, and may be infected by free-tailed bat lyssavirus variants.

Several caves were found to be occupied by the two bat species. About 200,000 of the migratory free-tailed bats were in a large but shallow cave that also harbored 15 common vampire bats in a deep side tunnel. The free-tailed bats had little protection from weather, which if cold would render them lethargic and helpless, and if wet and stormy would discourage their evening departure and the departure of the vampires. Either condition would make the free-tailed bats readily available to the vampires, which die if they do not feed for 3 nights (McNab, 1973). Lyssavirus variants from the

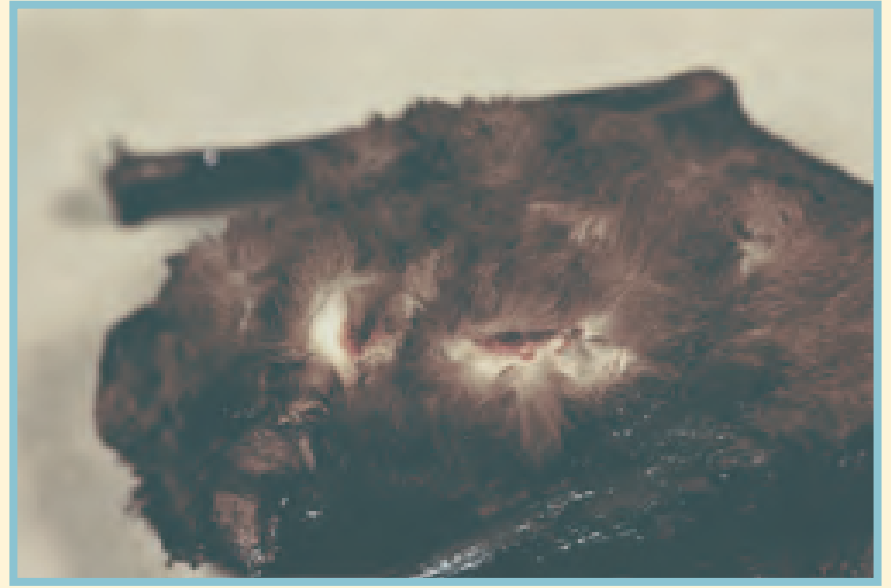

Brazilian free-tailed bat bitten and bled to death in captivity by a common vampire bat cage mate. (D.G. Constantine)

two species were later determined to be closely related (Franka and others, 2006). Other workers also found that captive vampire bats readily fed on insectivorous as well as frugivorous bat cagemates, and a frugivorous little yellow-shouldered bat in South America had a similar bite wound when it was captured in a cave shared with vampire bats (Lord and others, 1973). mission of rabies among North American carnivores following acquisition of virus from bats. In addition, these outbreaks contrast with earlier single isolated occurrences of evident bat rabies variant transmission to carnivores in areas otherwise free of rabies in carnivores (Smith and others, 2001).

\section{Europe}

Few interspecies transmissions of lyssaviruses from bats have been reported in Europe, however fewer investigations have been done in Europe than in other regions. The five European human deaths of European bat lyssavirus (EBL) origin (Table 5) were mentioned earlier: one from EBL-2 in Scotland (Fooks and others, 2002; Fooks and others, 2003), one from EBL-1 in Russia (Selimov and others, 1989), one from EBL-2 in Finland (Lumio and others, 1986), and two from uncharacterized lyssaviruses in the Ukraine (Selimov and others, 1989; Botvinkin and others, 2005). In addition, three domestic sheep were reported infected with EBL-1 in Denmark (Stougaard and Ammendrup, 1998a; Stougaard and Ammendrup, 1998b), and a stone marten was infected with the same virus in Germany (Müller and others, 2001). It seems improbable that insectivorous bats would attack sheep, and it is possible that the virus was transmitted by a carnivore, such as a fox or cat that was infected as it attacked a grounded bat. The EBL-1 variant also was isolated from nonnative Egyptian fruit bats in zoos that had previously exchanged animals with Denmark, the Netherlands, and Belgium (Ronsholt and others, 1998). Presumably the infection originated from a native bat. The EBL-1 virus is most often associated with the serotine bat, although it is known from at least three other bat species in Europe (Appendix D).

The EBL-2 virus is known from two bat species, the pond bat in Denmark and the Netherlands and Daubenton's bat in Germany, Denmark, Switzerland, and England and Scotland in the United Kingdom. Transmissions of lyssaviruses from bats to other mammals seem to be rare in Europe, where most infected bats have been found in areas apparently free of infection in other species, comparable to many areas of North America. 


\section{Africa}

Four lyssavirus species are currently known from mammals in Africa: classical rabies, Duvenhage bat, Lagos bat, and Mokola. Each of the four is divisible into variants, and the existence of multiple hosts for each virus species suggests previous interspecies transmission. Classical rabies is present in humans and in domestic and wild mammals, but it has not been identified in bats outside of the Americas. Only Duvenhage and Lagos bat lyssaviruses are currently known in African bats. In 1970, 2006, and 2007 Duvenhage bat virus caused the rabies-like deaths of two men in South Africa (Meredith and others, 1971; Paweska and others, 2006), and of a woman in Kenya (van Thiel and others, 2008). Each of these people were bitten or scratched by unidentified bats, although the bat in one case was said to have resembled the insectivorous long-fingered bat. Duvenhage bat virus has since then been recovered in South Africa from another bat resembling that species (Paweska and others, 2006) and in Zimbabwe from the insectivorous Egyptian slit-faced bat (Foggin, 1988). Additionally, an incompletely characterized lyssavirus was found in an unidentified bat in Zambia (Ahmadu and Zulu, 1998).

Lagos bat virus is known in straw-colored fruit bats in Nigeria and Senegal, Peters' lesser epauletted fruit bat in the Central African Republic, Wahlberg's epauletted fruit bat in South Africa, and in the insectivorous Gambian slit-faced bat in Senegal. In addition, it was reported in a domestic dog in Ethiopia, two domestic cats in South Africa and Zimbabwe, and a water mongoose in South Africa (Markotter and others, 2006a; Markotter and others, 2006b). Experimental infections of Lagos bat virus were demonstrated in dogs and rhesus monkeys (Percy and others, 1973). No human infections are known, but during a Lagos bat virus outbreak among fruit bats in South Africa, a motorcyclist was pursued and bitten on his face by a bat, which escaped. The bite victim received antirabies prophylaxis and did not develop clinical disease.

Mokola lyssavirus has not been confirmed in bats. Two human cases were identified in Nigeria; one of the victims survived (Familusi and others, 1972). The virus has also been isolated from an insectivorous rusty-bellied brush-furred rat in the Central African Republic (Saluzzo and others, 1984), a domestic cat in Ethiopia (Mebatsion and others, 1992), and domestic dogs and cats in Zimbabwe and South Africa (Foggin, 1982; Foggin, 1985; Sabeta and others, 2007). Mokola was also found in insectivorous Crocidura shrews in Nigeria and Cameroon. An association between shrews and bats is evident from observation of a Crocidura shrew feeding on an Angolian free-tailed bat within an attic colony (Osborne and Osborne, 1981). Experimental infections were demonstrated in genets, a mongoose, a jackal, dogs, and rhesus monkeys (Foggin, 1985; Percy and others, 1973).
Asia

Human lyssavirus infections from uncharacterized lyssavirus species were reported in two people previously bitten by bats; one infection was in a person in India who handled a disabled bat (Veeraraghavan, 1955) and the other was in a person in China, where a survey later disclosed infections in 3 of 300 unidentified bats (Tang and others, 2005). Similar infections were reported in the greater horseshoe bat in Turkey, the northern bat and Daubenton's bat in the Asiatic part of the Russian Federation, and the Indian flying fox in India. Aravan lyssavirus was discovered in the lesser mouse-eared bat in Kyrghystan (Arai and others, 2003; Botvinkin and others, 2003), and Khujand bat lyssavirus was recovered from the whiskered bat in eastern Siberia. However, a 1967 report of rabies infection in two bats in Thailand (Smith and others, 1967) was later reported to the author by the laboratory of origin to have likely resulted from laboratory contamination rather than originating from the bats in question.

A survey of healthy bats in the Philippine Islands failed to yield lyssaviruses from 821 insectivorous or frugivorous bats, which is similar to the results from earlier surveys of clinically normal bats globally, but 9.5 percent of 231 bats had antibodies against Australian bat lyssavirus (Arguin and others, 2002). Similarly, no lyssaviruses were recovered from 212 healthy bats in Bangladesh, but 3 of 127 Indian fruit bats had antibodies against the bat lyssaviruses Aravan and Khujand (Kuzmin and others, 2006). Sampling of bats in Thailand indicated that 15 of 335 Lyle's flying fox fruit bats and 1 of 45 lesser dawn fruit bats had antibodies against Aravan, Khujand, Irkut, or Australian bat lyssaviruses (Lumbertdacha and others, 2005). The survey results were interpreted as evidence of the presence of lyssaviruses but of a low prevalence of infection.

\section{Australia}

Australia was considered free of lyssaviruses until 1995, when a new lyssavirus species (genotype 7), now known as Australian bat lyssavirus, was first observed to produce signs of aggression and, ultimately paralysis and death in black flying foxes (Fraser and others, 1996). Some infected bats repeatedly and severely attacked and bit others of the species, including the offspring of one attacker. By 1999, surveys found the virus in 42 flying foxes, including members of 3 additional species: the little red flying fox, the gray-headed flying fox, and the spectacled flying fox. In addition, an Australian bat lyssavirus variant was found in four yellow-bellied sheathtail bats (Warrilow and others, 2003). Two female bat caregivers are now known to have died of the disease, one from the sheathtail bat variant and the other from a flying fox variant (Mackenzie, 1999). As mentioned above, antibodies against Australian bat lyssavirus were detected in bats in the Philippine Islands and in Thailand, indicating distribution of the virus well beyond Australia (Arguin and others, 2002; Lumbertdacha and others, 2005). The existence of multiple 
variants of this virus in various host species suggests past, if not continuing interspecies transmission, the latter demonstrated by the human cases.

\section{Environmental Persistence}

Rabies mortality in bats usually goes unnoticed because many bats die in their shelters, while others fall with folded wings into dense vegetation. Even multiple mortalities may hardly be noticeable for similar reasons. In some ways, bat mortality from rabies is comparable to a grass fire. The virus is represented by a burning match and the host mammal population by a field of dry grass. If a lit match drops where the grass is dense, a substantial and noticeable fire results, destroying nearly all of the grass. In time the grass regrows and the process may be repeated. However, if the grass blades are widely separated, only one or a few blades may burn unnoticed - the density of the grass being the key factor. Similarly, if a bat population is dense, it supports rabies transmission between individuals more readily, and thus the population is reduced (Constantine, unpub. data). Rabies infections may not be obvious in less dense populations.

Cyclic fluctuations and environmental persistence of bat populations and lyssaviral infections are influenced by several main factors (Fig. 18). A favorable climate is required to produce the plant base of the bat food supply: insects for insectivorous bats, fruit for frugivorous bats, and cattle as the blood source for vampire bats. Additional factors, differing by bat species, include such things as antibody systems and the amount of antibodies in the body, solitary or colonial habits, hibernation or migration habits, the numbers of young or litters produced per year, and alternate virus transmission routes. In addition, prolonged incubation periods provide a mechanism for virus persistence during the winter (Box 8). The overall effect of natural lyssavirus-caused mortality in bats may contribute to keeping host populations and food resources in balance without doing irreversible harm to either. This "balancing act" works despite some ghastly aspects of the scenario.

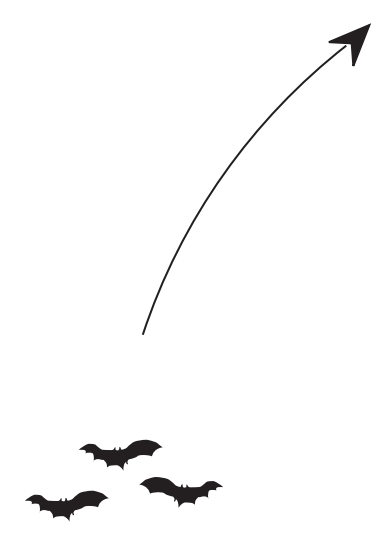

Population decline: low frequency of contact

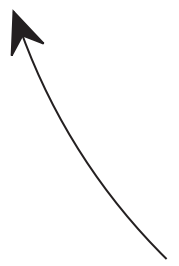

Figure 18. Factors involved in cyclic fluctuations and environmental persistence of bat populations and lyssaviral infections.

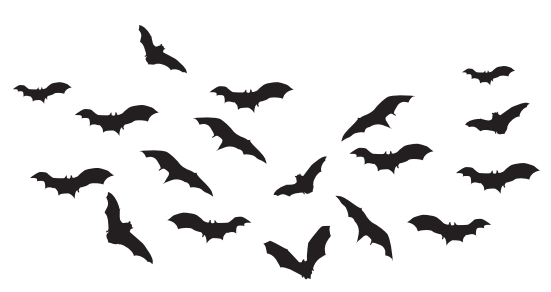

Population increase: favorable environmental conditions
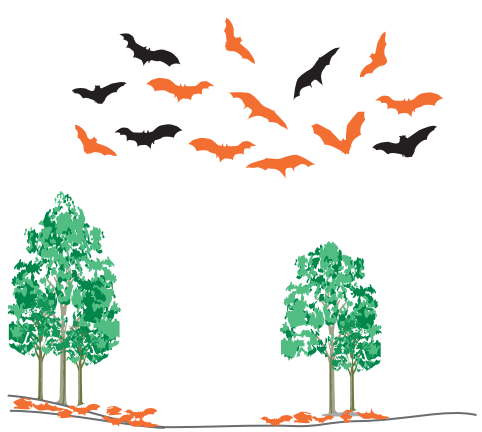

Spreading infection and mortality

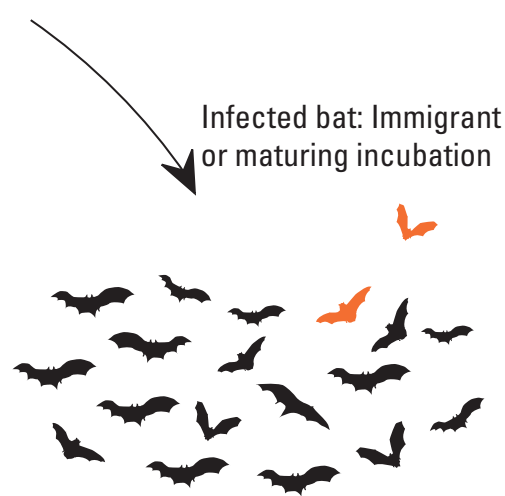

Population recovered: high frequency of contact

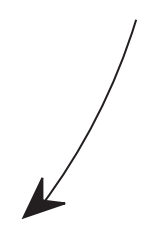




\section{Lyssaviruses-Deadly Hitchhikers}

Long incubation periods, in some cases extended by hibernation, enable rabies virus and other lyssaviruses to survive within seemingly healthy bats for more than 7 months before the appearance of clinical signs of disease. During this period of apparent dormancy, a migratory bat may transport a virus along both legs of its journey of as many as 4,000 kilometers. For example, a big brown bat that was captured in North America before winter hibernation, and kept active and isolated all winter while fed in captivity, developed rabies 7 months later or 1 month after it would have awakened from hibernation (Moore and Raymond, 1970). Two Townsend's big-eared bats of North America, awakened from hibernation in mine tunnels in New Mexico and adapted to captivity in a warm environment, developed the disease nearly 3 months later, or about 7 months after they entered hibernation (Constantine, 1967a). Brazilian free-tailed bats that were caught in New Mexico and similarly held captive after they otherwise would have migrated southward died of rabies after periods of 7 days to 3 months (Constantine, 1967a). These examples illustrate methods by which bat rabies virus persists overwinter in the apparent or actual absence of bats.

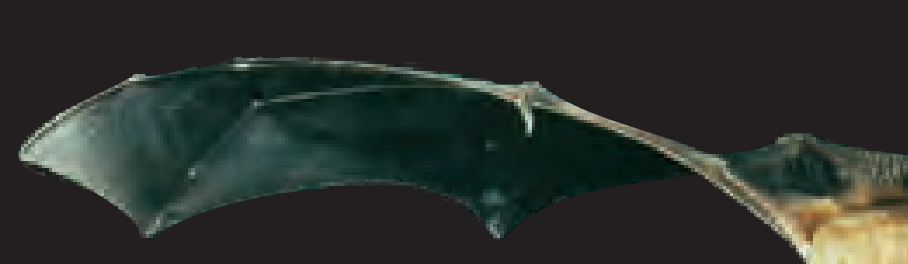

Big brown bat. (D.G. Constantine)

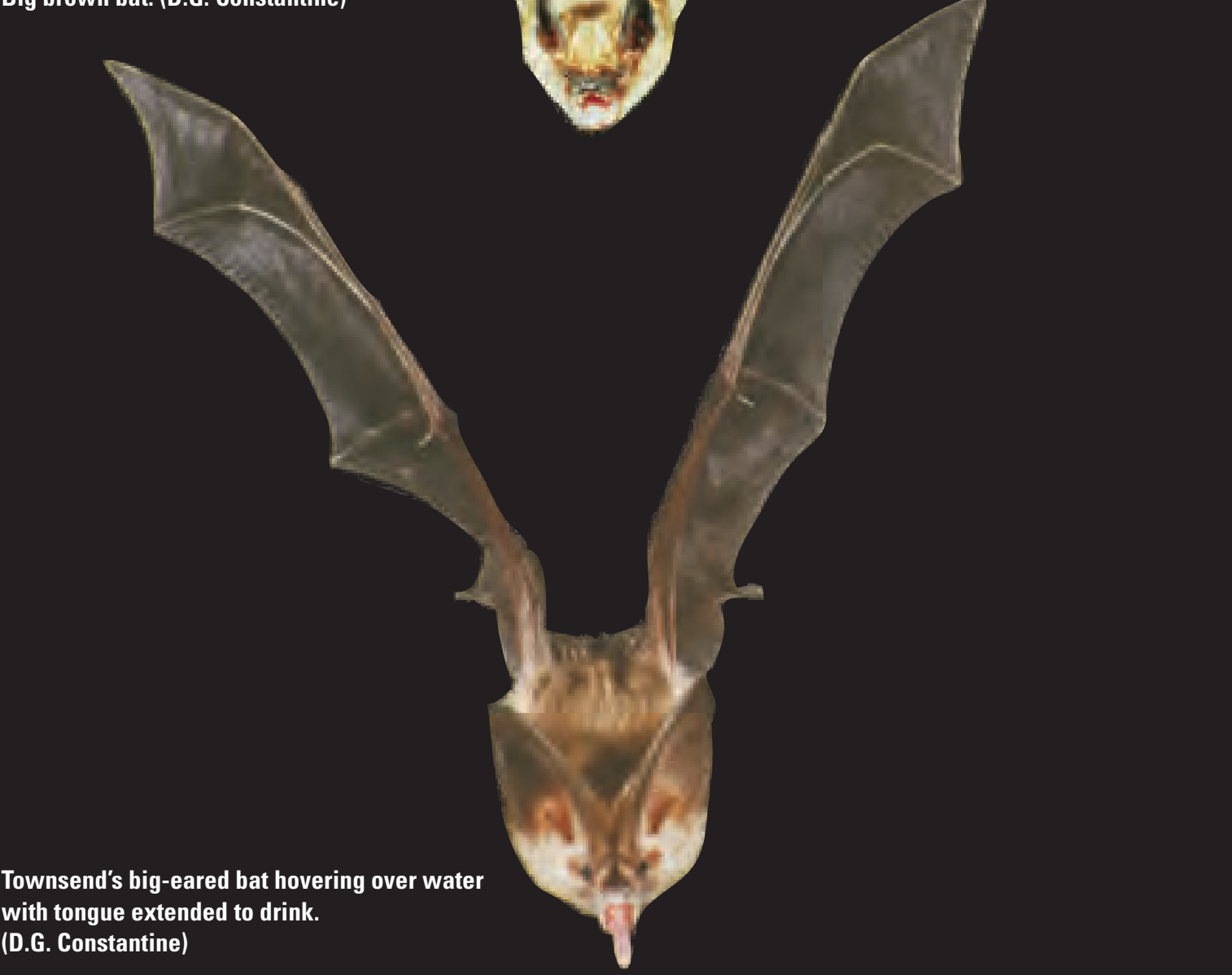
with tongue

(D.G. Constantine 


\section{Points to Ponder: Interspecies Interactions in Potential Bat Rabies Transmission Settings}

Intertwined with lyssavirus disease ecology are the interspecies interactions that develop when humans, their domestic animals, or other animals invade or otherwise interact in a setting where the potential for disease transmission exists. Cats play an especially important role in bat lyssavirus exposures (see Box 9 and Disease Prevention and Control).

\section{Bat Colonies in Manmade Structures}

Insectivorous bats have long provided services to mankind by controlling insects that attack and spread diseases to humans, livestock, crops, and forests (Constantine, 1970). Furthermore, vegetarian bats, as the sole pollinators and seed distributors of many major tropical food plants (Constantine, 1970), have and continue to make possible human and other life in tropical areas. Fear of bat rabies, however, has often resulted in the persecution of bats associated with manmade structures, and this fear has generally been fed by a lack of understanding of the ecology of bats.

Upon the discovery of bat rabies in the USA in 1953, frightening news stories repeatedly appeared, alarming homeowners and others whose buildings sheltered bats. Not knowing what to do but agreeing with public demands that killing the bats seemed appropriate, government agencies readily obliged by turning their mosquito control DDT foggers against bats and encouraged others to do likewise. Other toxicants were used after DDT was banned (Tuttle, 1988). This reaction resulted in widespread grounding of poisoned bats, which resembled rabid bats. An approximately tenfold increase in bitten people and pets followed, and most people received antirabies treatment and pets either were destroyed or quarantined after biting bats were discarded or escaped. A cycle of near-hysteria developed as poisons in typically unclosed bat harborages continued to act, sickening replacement bats for many years, leading to further poison applications and more frightening news coverage. Finally, efforts by those who understood these events prevailed over panic and politics, and toxicant use fell into disrepute (Tuttle, 1988).

Bats usually take shelter in elevated sites from which they can easily take flight (Figs. 19 and 20). They are noticeable due to their squeaking vocalizations, departures and arrivals, accumulations of droppings under their entry sites, or odors. Bats ill with lyssavirus infections may occasionally fall from these colonies (Fig. 21), whereupon predators such as cats, or curious people, are attracted to them resulting in bites and disease exposures. Whereas uninformed or fearful people often assume that destruction of bat colonies is the evident solution, that act is counterproductive, and a compromise such as excluding rather than killing the bats may benefit both bats and humans.

The exclusion of bat colonies and the sealing of bat shelters to prevent reentry are sometimes appropriate, especially when large colonies are located in school buildings where children may pick up fallen bats and be bitten. In another example, hundreds of bats were lodged in slots under an urban concrete bridge, from which boys pried dozens of young, flightless bats and threw them through the open windows of passing automobiles (Constantine, unpub. data). Ordinarily, exclusion of bats should not be undertaken until all of the young bats can fly and join mature bats on nightly foraging flights, which usually occurs by late summer or early fall. Otherwise, the young bats will be sealed inside the shelter to die and decompose, or they may crawl into building interiors where human and pet contacts may result. Exclusion is achieved by sealing all but the main exit and entry passages and arranging simple one-way valve-like systems over the exits, permitting bats to leave but preventing re-entry (Fig. 22) (Constantine, 1982b; Frantz, 1986).
Figure 19. An evening foraging flight of Brazilian free-tailed bats. (D.G. Constantine)

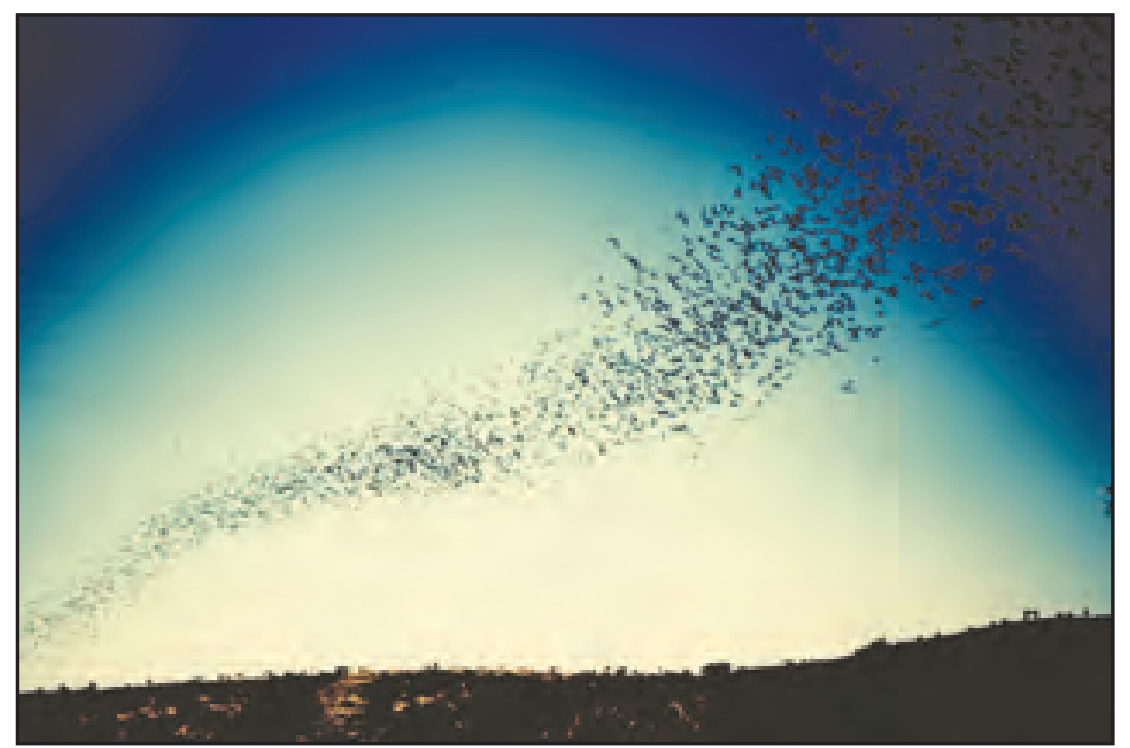



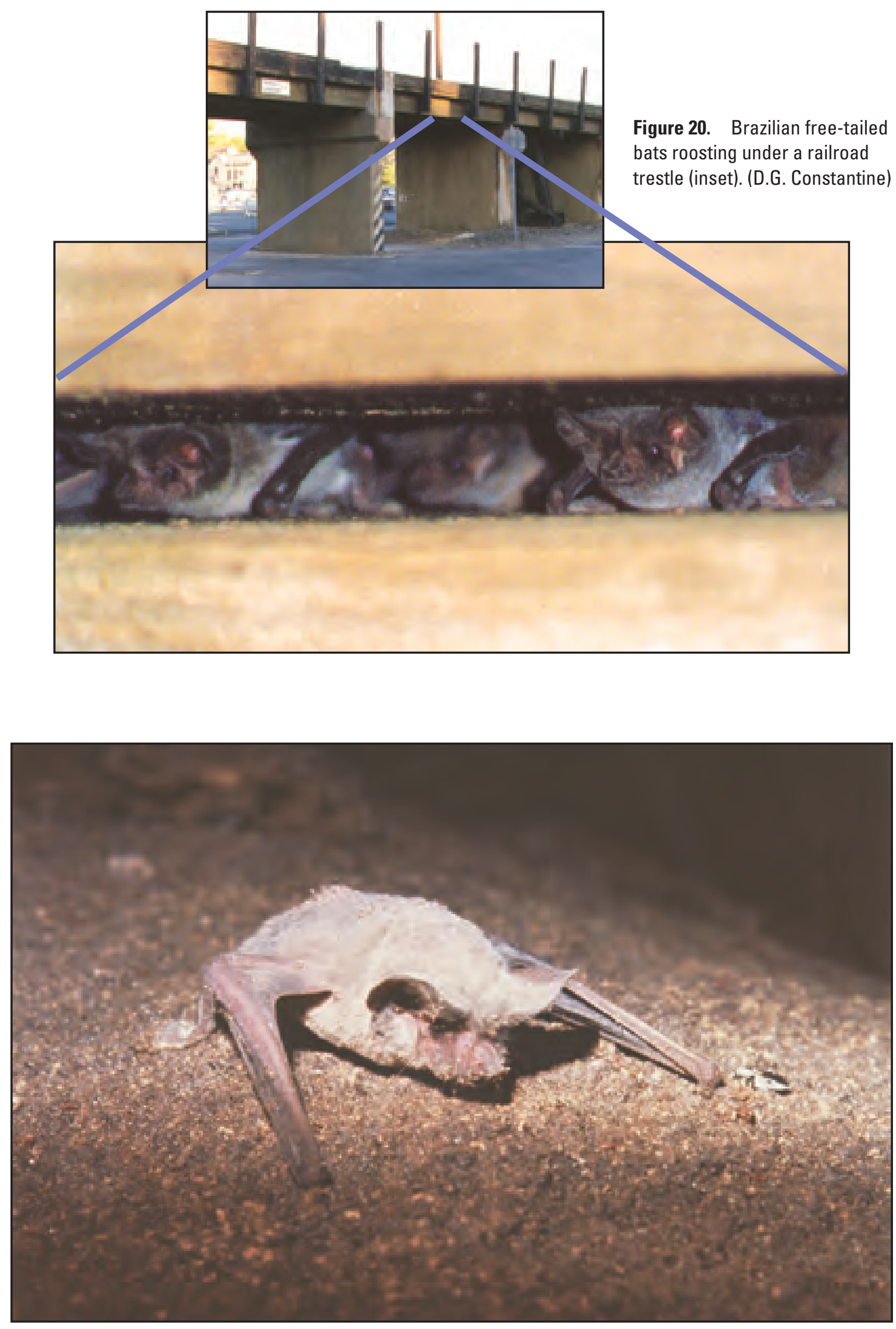

Figure 21. A dead Brazilian free-tailed bat lying on the guano-covered floor of a bat cave. (D.G. Constantine) 


\section{Domestic Cats and Lyssavirus Transmission}

It was easy to comprehend the extreme concern of a panicked mother who found her baby mouthing a bat delivered by the family cat (Constantine, unpub. data). In areas of the world where domestic cats are popular as pets or for rodent control, they are the primary predators of bats. The irrepressible hunting habits of domestic cats---and their practice of bringing home their victims---accounts for the great majority of contacts between people and bats. In the USA, approximately 10 percent of bats that are home-delivered by domestic cats prove to be infected with lyssavirus.

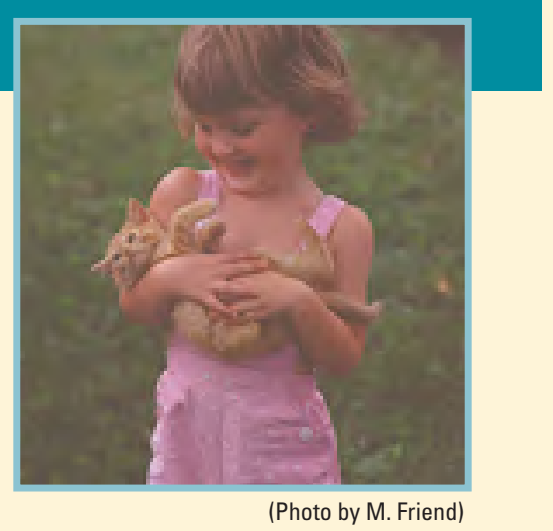

Cats readily jump fences to forage widely, whereas dogs are restricted to yards or tethered where they may be left with a bat courtesy of the family cat. Reports from 1 California county over a 14-year period revealed that 1 or more resident cats were found with 428 (66 percent) of the 649 seemingly ill, injured, or dead bats that appeared at residences. Dogs and cats were present together with 26 of the bats (4 percent), but only dogs were found with 52 of the bats (8 percent), an unknown number of which may have been delivered by resident cats (Constantine, unpub. data).

As mentioned elsewhere, most individual temperate zone bats become inactive when they are resting, are ill or injured, or as a consequence of cool ambient temperatures. These bats may appear to be dead and are easy prey for cats. A cat sometimes enters a residence with an unnoticed bat in its mouth, and having delivered its catch, the cat usually loses interest in the seemingly lifeless bat and leaves it on the floor. Later, as the bat warms, it seeks a vertical surface where it can climb to safety or a site from

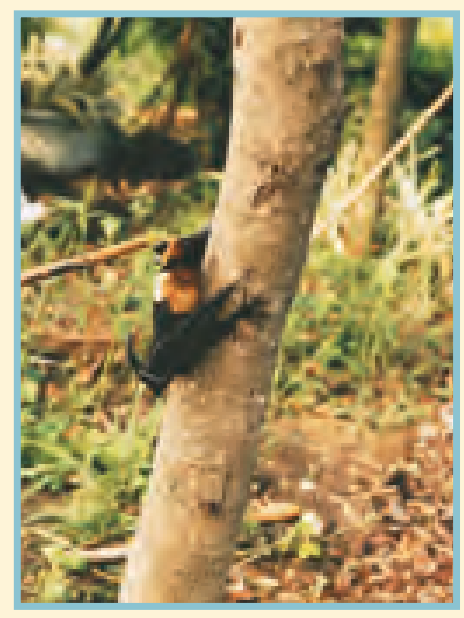

which it can launch itself into flight. Alternatively, especially if the bat is ill, it may remain hidden during daytime and initiate its upward climb after dark. The bat may climb blankets onto a bed or be chilled by the night air and seek a warm place, possibly next to the body of a sleeping human. As the person turns during the night and makes contact with the bat, it may inflict a retaliatory bite that might not awaken the sleeper. This scenario has occurred many times, involving infected as well as uninfected bats, and human rabies mortality likely has resulted. Six such rabies exposures are recorded in California (Constantine, unpub. data).

Cats generally bite and chew to stun, kill, or eat a bat, and if the bat is infected then the interior of the cat's mouth can become contaminated with virus. Two relevant hazards can result: (1) the contaminated mouth of the cat may temporarily have the ability to mechanically transmit the virus by bite, by licking the virus into even slight wounds or onto mucosal surfaces, or by scratches with claws (Tabel and others, 1974) that were licked previously during cleaning or preening; (2) the cat may ultimately develop the disease, especially if it was not previously vaccinated, often vanishing to die in hiding as overt signs appear. Twenty-six likely human rabies exposures in California resulted from people being bitten by cats while they were trying to extract rabid bats held between the cat's teeth (Constantine, unpub. data). The possibility also exists for virus transmission through aerosolized oral or nasal fluids expelled as a cat sneezes, which is a demonstrated route of transmission for plague (Gage and others, 2000). Variations of such disease exposures could follow unobserved encounters between cats and infected bats and may account for many of the unexplained human lyssavirus deaths involving virus variants characteristic of bats but lacking histories involving bats. 
Through variations of the scenarios described above, domestic cats are likely intermediate rabies hosts or vectors between bats and humans. Cats are relatively resistant to rabies; a cat exposed to rabies may never develop the disease and thus be above suspicion. In laboratory experiments, striped skunks could be infected by eating the carcass of a single mouse infected with rabies virus of silver-haired bat origin, but cats fed 25 such carcasses were not infected (Bell and Moore, 1971). Moreover, a cat may eat an infected bat and return home with a contaminated mouth and claws. Alternately, a cat may eat a rabid bat after it has bitten a person, thus precluding the bat from being tested and consequently discouraging the human bite victim from seeking treatment. This happened in Wisconsin in 1959, and it resulted in a documented human rabies mortality (Humphrey and others, 1960).

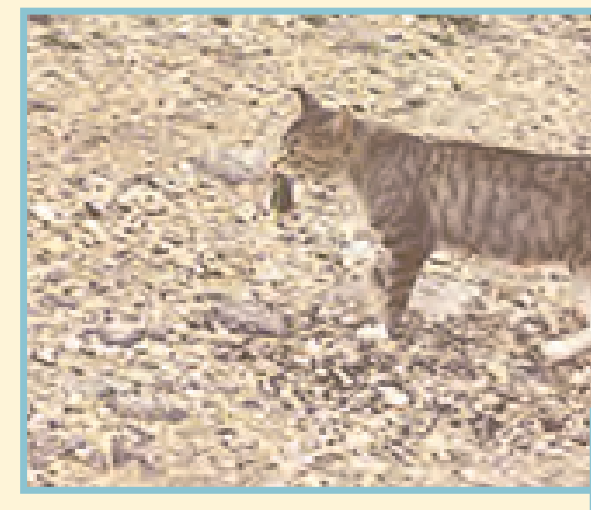

Rabies in cats is a "spillover" or incidental infection transmitted to a cat by a reservoir host: a rabid dog, wild carnivore, or bat. In the USA, annual reports of rabid cats ranged from 200 to 500 cases per year between 1938 and 1960 (Rupprecht and Childs, 1996). During this same time period, however, dog rabies cases typically outnumbered cat cases by a factor of 10 or more (Rupprecht and Childs, 1996). Canine rabies vaccination campaigns initiated in the 1950s led to a drastic reduction in dog cases, but at the time, far less emphasis was placed on cat rabies vaccination. Thus by 1981, as dog rabies came under control, cat rabies cases increased so that they exceeded dog cases and they have maintained their lead since.
This trend may be explained by the popularity of cats as pets, by their relative risk of encountering rabid animals when allowed to roam freely, and by difficulties in the enforcement of mandated cat rabies vaccination (Rupprecht and Childs, 1996). In addition, since the discovery of bat rabies in the USA in the early 1950s and the consequent alarm when cats bring home rabid bats, increasing numbers of cats have been sacrificed and tested for rabies. The relative rabies resistance of cats, coupled with the lower rabies dose received from a typical bat bite, probably results in fewer cat rabies infections from bats than from bites that roaming cats may receive from rabid skunks, foxes, or raccoons. However, this does not diminish the danger to people from mechanical or biological transmission of rabies by pet cats.

The obvious solution to this problem is to keep domestic cats confined indoors and to ensure that they are up-to-date on vaccinations. Hunting cats bring home an amazing variety of diseases and disease-transmitting parasites that they either carry themselves or have acquired from wildlife. Some diseases acquired this way by humans, such as plague (Gage and others, 2000; Baldwin and others, 1991), are treatable if they are recognized early enough, but only three or four people are known to have survived lyssavirus infections. Stray cats and

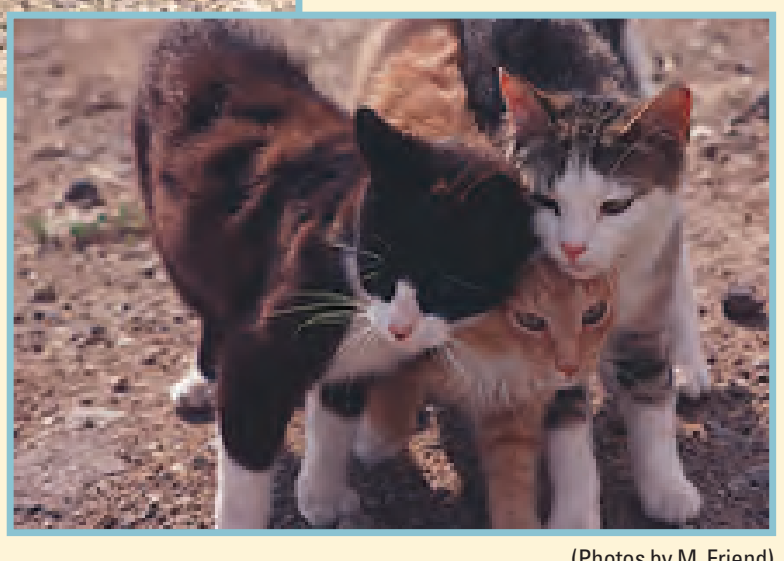

feral cats may also transmit diseases and parasites--including some feline diseases that neutralize the protective effects of vaccinations--to owned cats (Pedersen and others, 1985; Yamamoto and others, 1989). The prompt testing of bats that are found under circumstances resembling any of the foregoing scenarios may reveal lyssavirus infection, and thus initiate prophylaxis specific to the found variant to potentially infected humans. Management of pets as directed under Disease Prevention and Control would decrease disease transmission to other pets, wildlife, and people. 


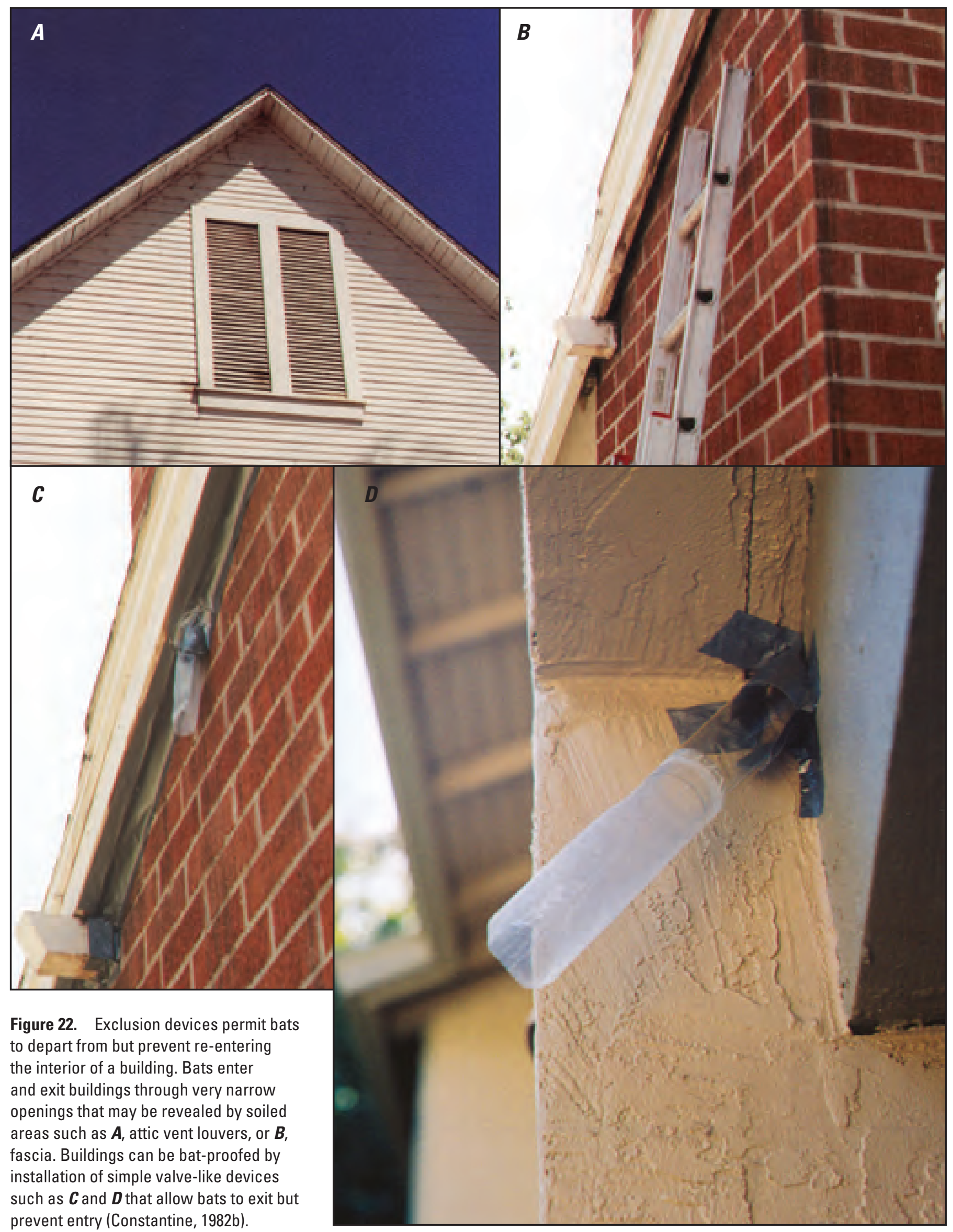




\section{Bat Colonies in Caves and Mine Tunnels}

Most caves or mine tunnels in North America are devoid of bats. Some, however, may be inhabited only in summer, others only in winter, and still others year-round. If bats are present, their numbers usually vary from 1 to 30 , but sometimes to several hundred or more. Some bat species hide in crevices, but others are more exposed and obvious. Summer shelters are warm to hot, and bats may be active. Winter shelters of most species are cold, facilitating the hibernation of bats, individually or in compact groups.

Some bats do not survive human intrusions due to injuries or predation outside or inside the shelter, and human intrusion may cause bats to abandon shelters. Hibernating bats often slowly awaken and move to safer places after someone tries to noiselessly sneak past them, which can sometimes result in the loss of sufficient body fat for the bat to survive until spring. When a person enters in summer, pandemonium can result as bats panic to avoid intruders. Some bats may fly outside while others retreat to deeper sites to escape the intruder. Flightless suckling bats often become dislodged

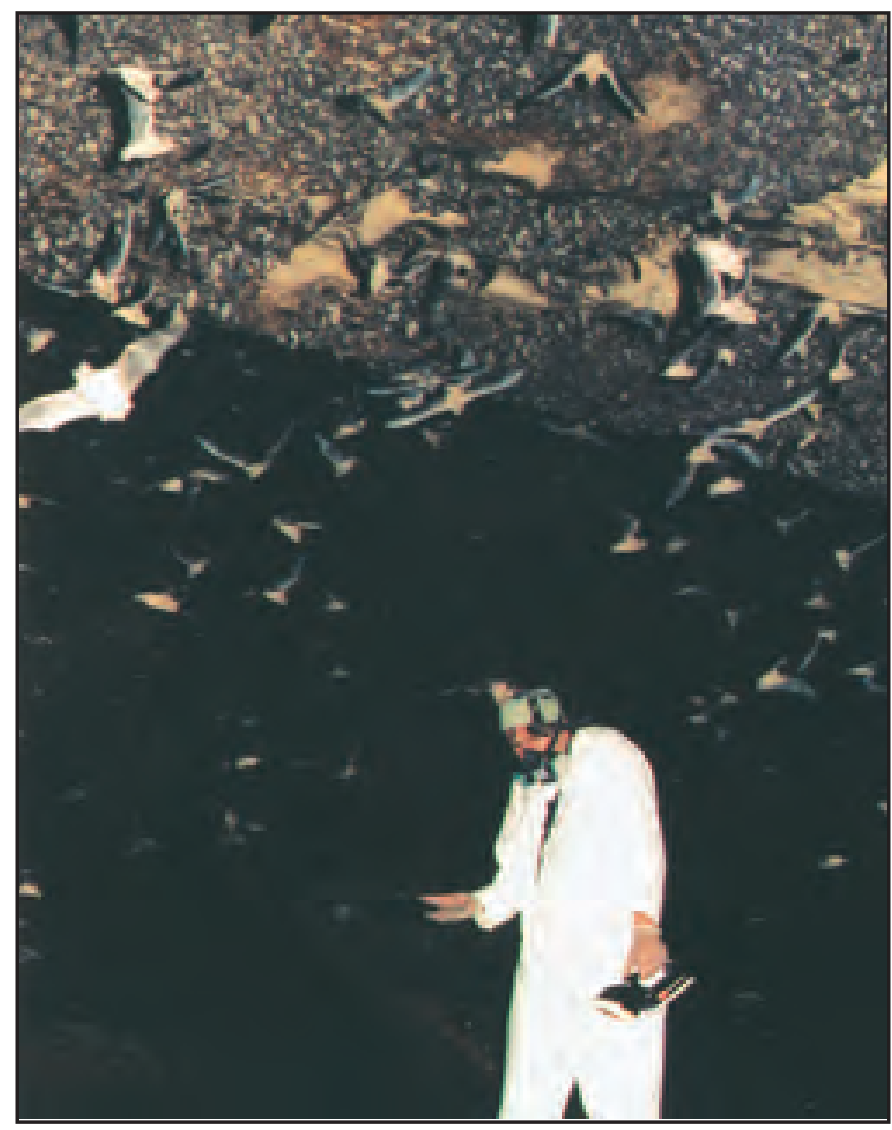

Figure 23. Researcher among a Brazilian free-tailed bat colony. Note the personal protective clothing and equipment worn, such as coveralls, gloves, respirator, and hat; eye protection is also recommended. (D.G. Constantine) and fall or are panicked into clumsy attempts at flight. Such young bats or distressed adults may fall or land on human intruders, who may be scratched or even bitten, especially if they slap or grab the bat. Thus, the intruder has experienced a potential lyssavirus exposure. Human avoidance of bat shelters benefits bats by removing the potential for disrupted hibernation, and benefits people by removing the potential for disease transmission from bats.

The danger of rabies transmission by inhalation of airborne virus is known to exist in caves occupied by many thousands to millions of Brazilian free-tailed bats (Fig. 23) (Constantine, 1967b; see also "Cave Explorations" below). This danger becomes greater as bat numbers increase or as cave space decreases proportionately, and similar caves crowded with other bat species in tropical areas pose similar danger. Prohibition of the entry of humans into such shelters during seasons of bat occupancy, except for persons willing to risk exposure after they have received proved effective pre-exposure antirabies immunizations, decreases the risk of infection by aerosol or other means of transmission. Depending on location, such visitors may also be exposed to excessive heat, humidity, noxious cave gasses (such as ammonia), carnivorous beetles, blood-sucking and other arthropods, snakes, mammalian predators ranging from skunks to jaguars, and other hazards, including histoplasmosis (Constantine, 1988a). The latter tuberculosis-like fungal disease is acquired by inhaling infective spores in guano dust. Relevant warning signs have been erected at some caves in the USA.

Special gates that permit bat passage but that block human entry have been installed at the entrances of some bat caves and mine tunnels to protect the much smaller groups of bats that shelter therein. However, similar gates would probably kill many bats as they rapidly enter or depart en masse at multimillion-bat colonies.

\section{Flying Bats that Enter Buildings at Night}

A flying bat occasionally enters a residence through an open window or door at night, because it recognizes the light inside as an attractant for its flying insect food. In this situation, the bat is likely to depart the same way it entered if doors to other rooms are closed to prevent it from getting lost in adjacent rooms. If the bat clings near the ceiling, it can be encouraged to leave by intimidation with a broom, or it may be captured carefully in a butterfly net or by placing an open coffee can over it and sliding a cardboard lid behind the can opening to keep the bat inside. Capture technique may have to be varied or improvised if the bat falls to the floor or does not cooperate. Such a bat is unlikely to be infected, but there are no guarantees, and bites or scratches should be regarded as potential rabies exposures unless the bat is quickly tested and proved uninfected. In the absence of skin contact, the bat may be released outside. Window and door screens discourage such bat visits. 
Alternatively, a bat may enter through an unscreened chimney, sometimes attracted by exiting warm air on cool evenings, or it may gain entry by unknown means. It may enter a darkened building at night seeking temporary rest, shelter from wind or rain, warmth, or perhaps a new home or stopover site while migrating, and it may be discovered the following morning. As with any mysterious appearance of a bat, one cannot know if the bat was delivered by a residentand thus potentially exposed - pet cat. One would prefer to be assured that no humans or pets have been exposed to rabies, but that is impossible, especially if the bat has been in a bedroom with a sleeping person. The teeth of many bats are sharp but short and may be capable of transmitting virus without awakening bitten persons or leaving detectable bite wounds. Healthy adults evidently have not awakened to bites, and others, such as infants, elderly, or medicated persons may be unable to perceive or communicate events. At least 30 percent of 51 North American human rabies victims were either awakened at night during a rabid bat attack or the bat was present in their bedrooms when they awoke in the morning (Constantine, unpub. data). Also, sound can precipitate rabid bat attacks, and any source of sound in an otherwise quiet bedroom may be a target. Snoring or even faint noises such as air movement through partially closed lips may suffice to attract a rabid bat.

\section{Unprovoked Attacks by Flying Rabid Bats}

Attacks on people and noisy pets by flying rabid bats are rare in the USA. Most reports involve the canyon bat (Fig. 10), which is abundant in the Southwest and prefers to shelter in rock crevices in cliffs. Fewer attacks are documented for the Western small-footed myotis (Fig. 11) and the California myotis (Fig. 12), both of which prefer to shelter in rock crevices, under loose tree bark, or other similar natural sites. All three species are strictly solitary and uncommonly take shelter in buildings. Flying attacks by rabid bats of other common North American species have been documented. The flying attacks are known to be swift and direct, and the bat is not seen until it has bitten the victim. That said, it seems superfluous to mention the only potentially preventive measure: do not make noise or do anything that may attract the animal's attention. Most attacks have occurred in daylight, so bats flying in daytime should be suspect. Daylight attacks by rabid bats have been reported in Latin America (Haupt and Rehaag, 1921; Torres and de Quieroz Lima, 1935; Pawan, 1936), but few case-specific details are available.

\section{Translocation of Bats}

Bats have been and continue to be accidentally and intentionally translocated by intra- and intercontinental ships, aircraft, and overland transport. Some of these bats may be incubating infectious diseases such as lyssaviruses. Bats are intentionally translocated to stock zoos or laboratory colonies and to supplement wild populations. Some bats intended for translocation have escaped en route to or at their destinations (Constantine, 2003). Only a small fraction of translocations are publicized, and they typically are highlighted only after information is released following accidents. Among various objections to translocations, especially when bats escape, are the potential introduction of foreign diseases that could impact humans and animals. For example, the recent introduction of West Nile virus into North America may have been due to the importation of thousands of foreign fruit bats for sale as pets and for exhibition (Constantine, 2003). In addition, a live little free-tailed bat was inadvertently transported by aircraft in a suitcase from South Africa to Los Angeles. This species is one of the very few known to support the experimental replication of the Ebola virus without exhibiting clinical signs of the disease (Swanepoel and others, 1996). Increased regulation of the wildlife pet trade within the USA was urged following the accidental introduction of monkeypox virus, which was brought into the country by small African mammals intended for the pet market (Reynolds and others, 2007). The need for wildlife health certification for translocated and released wildlife has been elevated during recent years (Friend, 2006).

\section{Vampire Bats and Rabies}

Vampire bat populations, once dependent on native fauna for their blood meals, increased greatly following the introduction of domestic livestock throughout Latin America (Greenhall, 1988). Three different vampire bat species are involved in rabies transmission (Box 10). Rabies outbreaks in vampire bats (Fig. 24) have been observed to "migrate" throughout vampire populations, often along rivers, leaving a wake of death as the disease kills both the bats and livestock. Because vampire bats prefer feeding from cattle, the bats usually turn to other victims, including people, only after cattle die or are moved seasonally to distant pastures. Cattle depredations can be controlled by destroying vampire bat populations. This objective can be achieved through campaigns whereby petroleum jelly that contains an anticoagulant is applied to the backs of captured vampires (Fig. 25) that are then released to return home, where companion vampires lick off the jelly and perish as a consequence. Alternatively, the jelly is applied to wounds on bitten animals (Fig. 26) to poison vampire bats that return to the wounds on subsequent nights (Lord, 1988). 


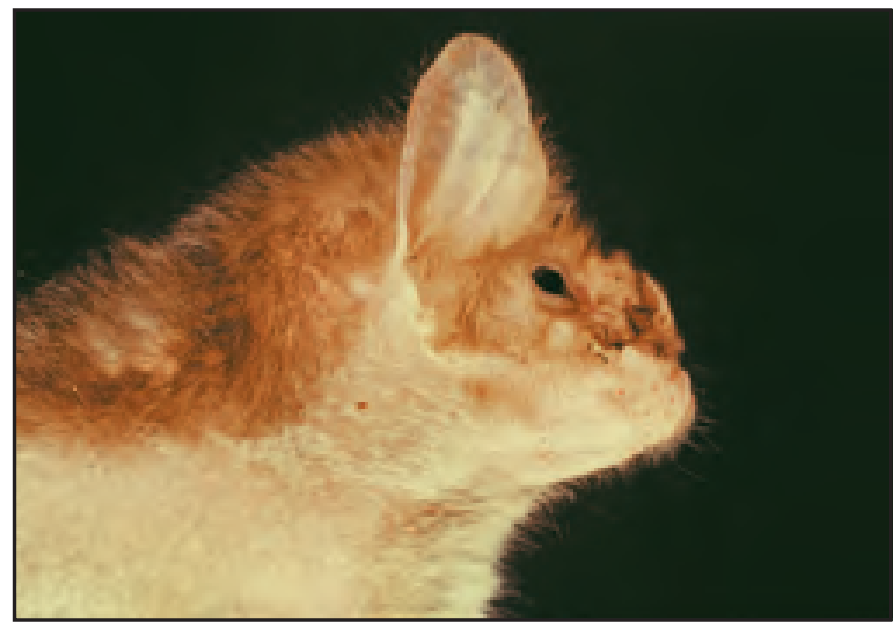

Figure 24. Common vampire bat. (D.G. Constantine)

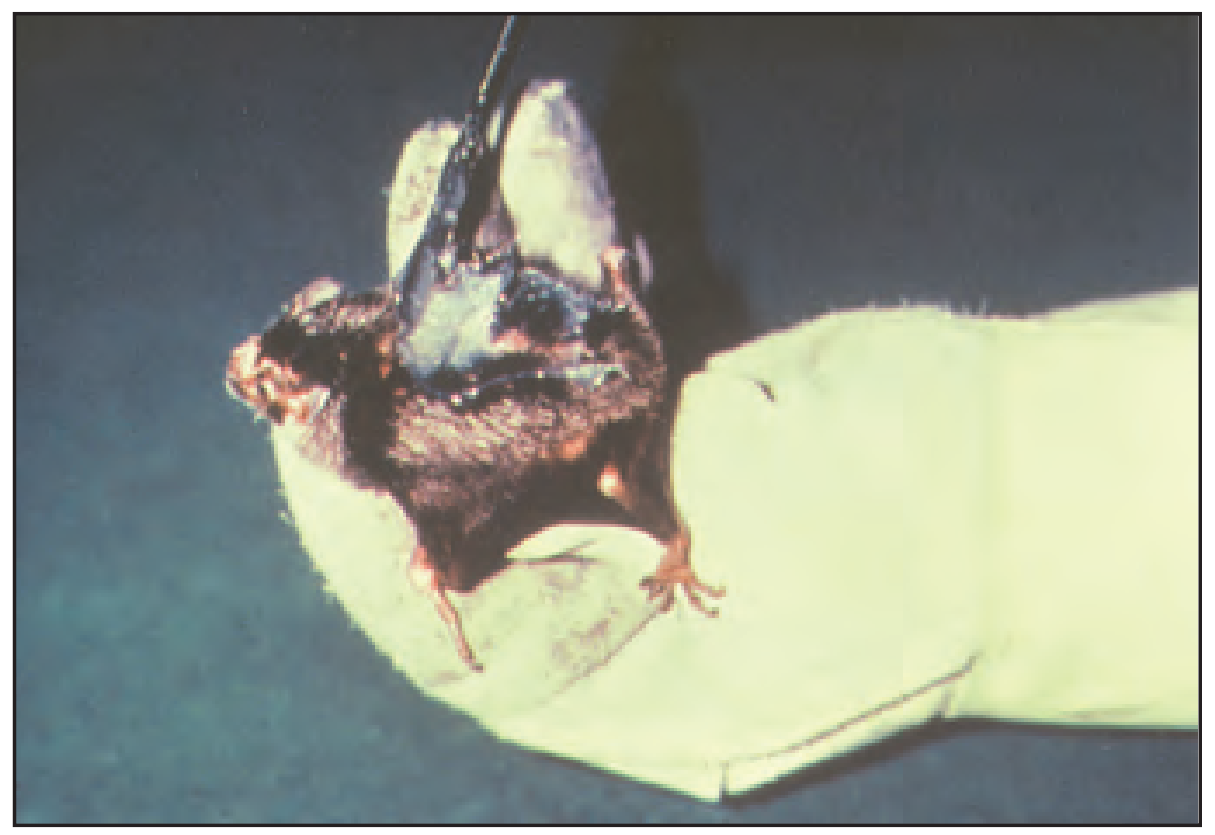

Figure 25. Application of anticoagulant jelly to the back of a vampire bat. (D.G. Constantine)

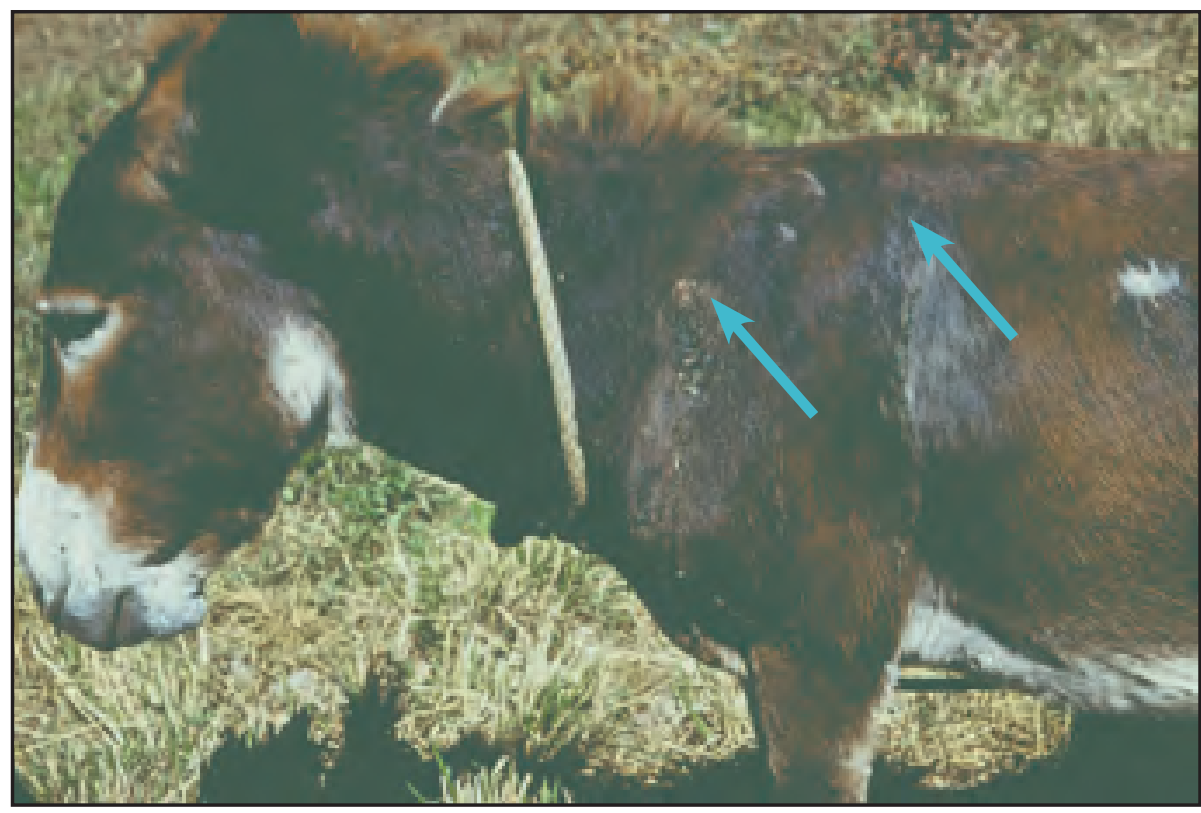

Figure 26. Vampire bat-bitten burro. (D.G. Constantine) 


\section{The Tripartite Vampire Bat Clan}

Although most references to vampire bats refer to the common vampire, two less abundant vampire bat species exist that prefer the blood of birds, including poultry. These species, the white-winged vampire and the hairy-legged vampire, bite birds on the legs or the cloaca region from the underside of branches on which the birds perch (Greenhall, 1988), but these bats will also feed on the blood of mammals, including humans.
All three vampire species are distributed from Mexico to southern Brazil or Argentina and exhibit unique characteristics and behaviors. The white-winged vampire bat has white wing tips and a large, bulbous gland within each of its cheeks, from which it can emit through its open mouth a jet of liquid similar to the anal scent gland secretion sprayed by skunks. In contrast, the hairy-legged vampire bat is solitary and retiring rather than gregarious and confrontational. The

Reported distribution of the three species of vampire bats: the common vampire bat (Greenhall and others, 1983), the hairy-legged vampire bat (Greenhall and others, 1984), and the white-winged vampire bat (Greenhall and Schutt, Jr., 1996).

\section{EXPLANATION}

Reported range of the common vampire bat (Desmodus rotundus)

Reported range of the hairy-legged vampire bat (Diphylla ecaudata)

$\star$ One hairy-legged vampire bat was found in the USA

- Documented geographic locations of the white-winged vampire bat (Diaemus youngi) 
common vampire bat frequently regurgitates blood to supplement milk for its progeny older than 3 months of age. It also shares regurgitated blood with females that failed to secure meals through predation. Such food sharing among adult vampire bats is performed on a basis of reciprocity, requests from previously uncooperative bats being rejected.
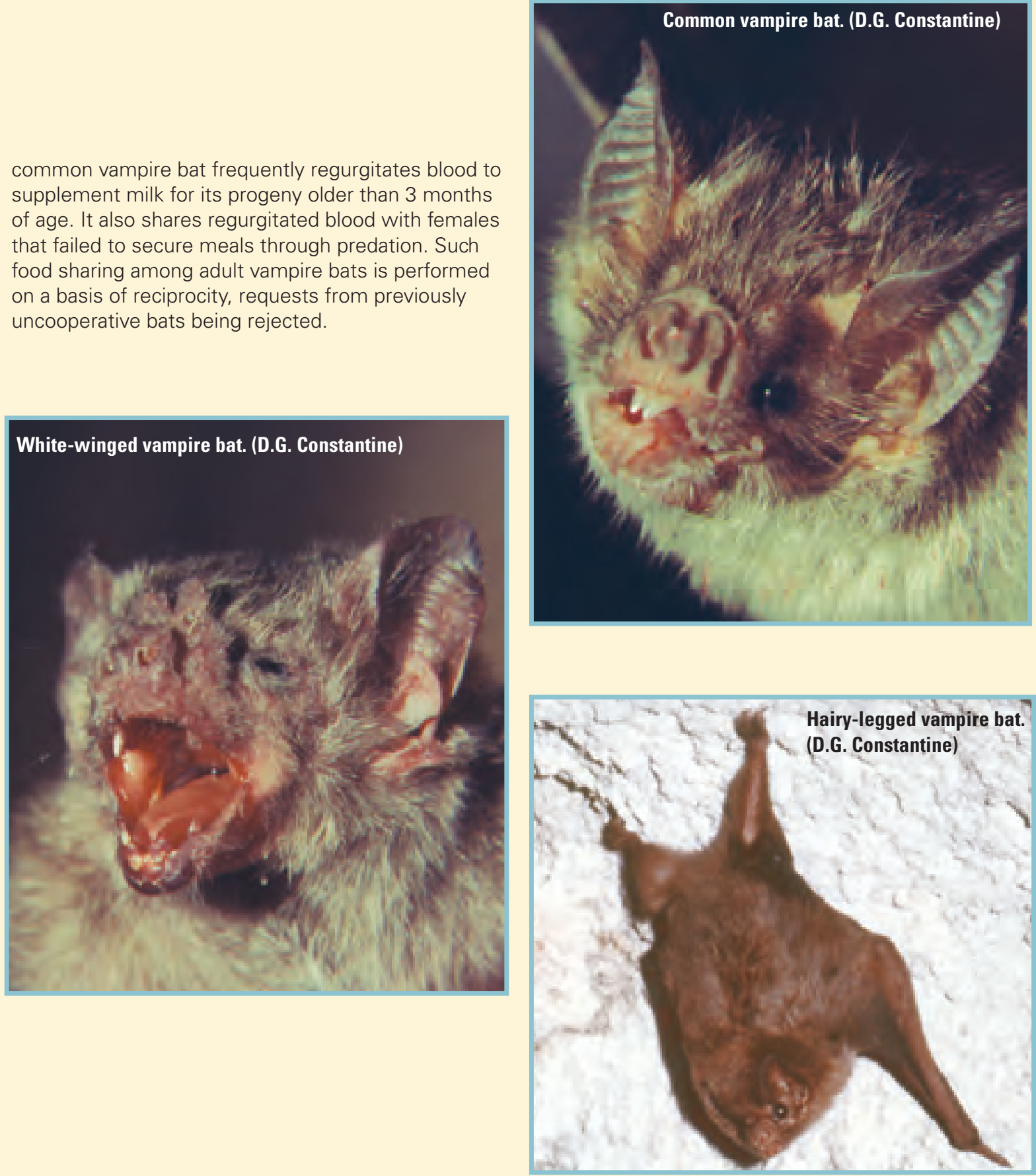

Three species of vampire bats would be sufficient, but current research indicates that the common vampire may be divisible into additional species (Martins and others, 2007). In addition, the presumed extinct giant vampire bat may yet be found living (Ray and others, 1988). 
Table 9. Diseases other than rabies that may be transmitted by vampire bats.

[The feeding habits of vampire bats provide a mechanism for mechanical transmission of infectious agents to their live animal food sources.]

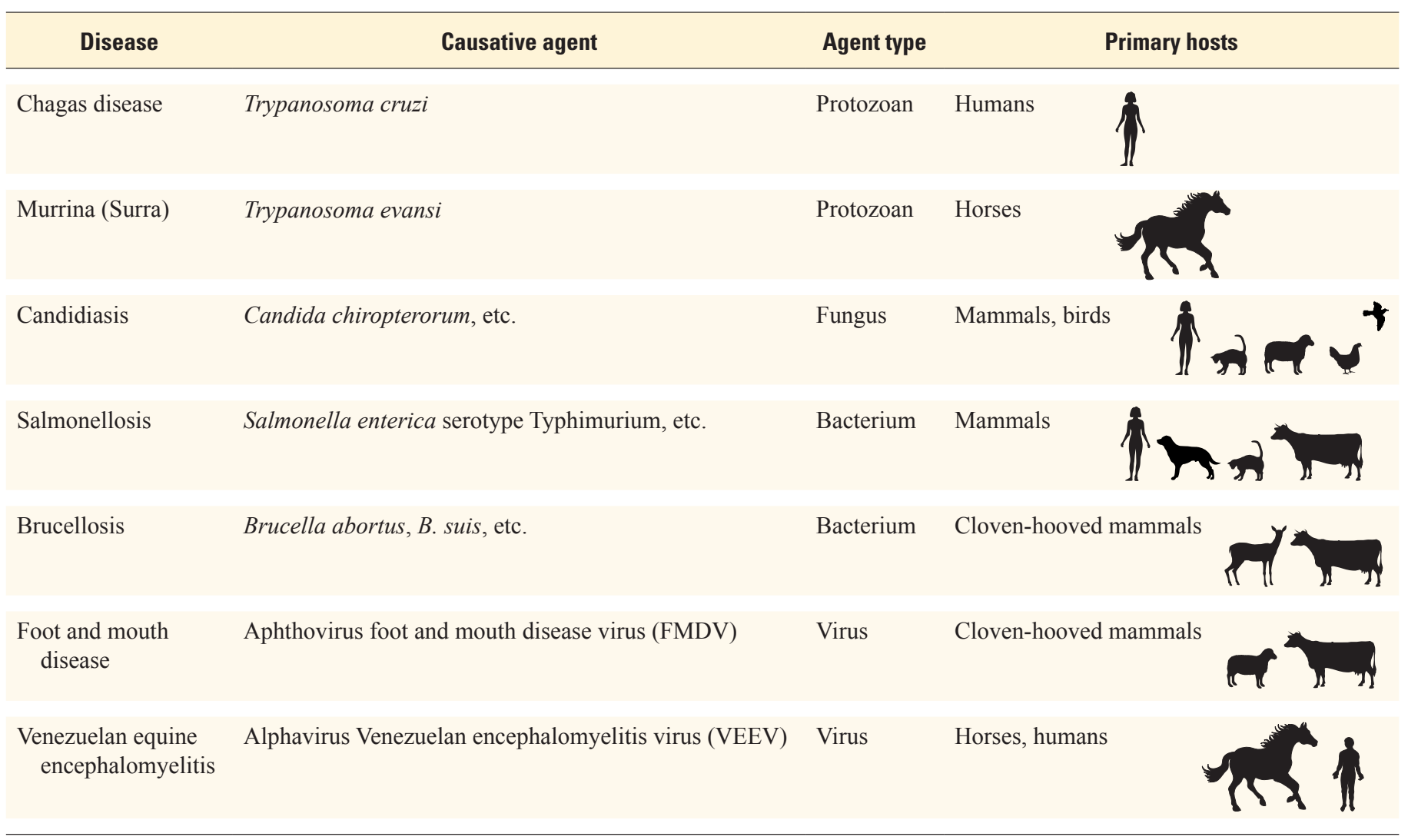

\section{Attacks on People}

Vampire bats may transmit numerous other known or potential diseases, in addition to rabies (Table 9) (Constantine, 1988b). Most vampire bat attacks on people are in undeveloped areas, where victims often do not recognize the cause of bites inflicted during sleep and darkness, or ascribe them to mythical agents such as witches, thus emphasizing the need for education. However, furious daytime attacks on people and animals have been reported during rabies outbreaks throughout Latin America (Pawan, 1936).

Physical exclusion of bats from the dwellings of remote native peoples most affected may be nearly impossible due to the primitive nature of these shelters and due to the lack of funding to construct more secure quarters. Infection would be preventable by pre-exposure antirabies vaccinations, which may be prohibitively expensive, or postexposure treatment with suitable vaccine and globulin products, which generally are neither affordable nor available. Under these circumstances, the potential for infection may be reduced by immediately and extensively washing the bite wound with soap and water, irrigating the wound with a virucidal agent, promptly testing the bat, and starting the patient on postexposure treatment. In view of the general unavailability of modern preven- tive measures, native peoples could benefit from revisiting the rabies-preventive measures that their predecessors taught the European explorers during the early 1500s: promptly cleanse vampire bat wounds and cauterize them with wood embers.

\section{Attacks on Livestock}

In addition to vampire bat population control methods mentioned above, vampire-borne rabies in livestock can be limited by various other methods, the most effective of which is antirabies vaccination of livestock. Recent studies have revealed the existence of at least three rabies virus variants that are circulating among vampire bats in Latin America, and each variant has a specific geographical distribution that may differ from or overlap with that of other variants (De Mattos, C.A. and others, 2001; Vargas Pino, 2001). Consequently, antirabies vaccines tailored to each or all of these variants might increase their effectiveness.

\section{Attacks on Domestic Dogs and Cats}

Vampire bats may expose companion dogs or cats to rabies while seeking blood meals or under other circum- 
stances (Box 9). Cats in particular may collect and deliver live or dead vampires, some captured as they attack the cat. Vampire bats can deliver exceptionally effective bites, and thus greater virus doses. They usually remove a divot of flesh about $1 / 8$ inch ( 3 millimeters) in diameter with each bite, and they will do so either defensively for protection or to obtain blood for feeding. Rabies of vampire bat origin has adapted to and is being transmitted serially among dogs, cats, and some other bat species in Latin America (Carrieri and others, 2001; Kotait and others 2001). Infected dogs or cats may then transmit rabies to humans or to other mammals. The prompt testing of a rabies-suspect vampire bat may indicate if it is infected. If the bat involved in an attack is unavailable or unsuitable for testing, or if testing is delayed, then the bat should be considered infected and known or potentially exposed subjects should be managed accordingly (see Disease Prevention and Control). This problem can be limited by vaccinating pets against rabies and confining them to prevent their contact with vampire bats. Control of stray and feral dogs and cats would mitigate their chance of infection and subsequent roles as virus sources.

\section{Attacks on Other Bats}

Vampire bats deliberately attack other mammals, including other bat species, for blood meals, and other bat species serially transmit vampire rabies variants (Lord and others, 1973; Silva, 2001; Table 8). It is unknown if such changing of hosts will affect the nature of disease in the new host, such as changing a predominantly paralytic disease to a predominantly furious disease. Reports of furious rabies in various species of bats in Latin America are increasing, but more definitive evidence would delineate, qualify, and quantify relevant facts pertinent to devising appropriate responses or solutions.

\section{Disease Prevention and Control}

Preemptive actions to minimize exposure to rabid bats are possible (Table 10), and they can be highly effective when they are combined with sensible behaviors, such as avoiding hazardous situations and seeking treatment following potential exposure. When someone is potentially exposed to disease after being bitten by a bat or another mammal, the wound should immediately be scrubbed with water and soap and preferably irrigated with a virucidal agent, such as povidone-iodine solution. The victim should simultaneously take steps to initiate subsequent antirabies treatment. In addition, prompt testing of the bat may provide information valuable to treatment of the victim. However, if the bat is lost among a group of bats, one must consider whether it is possible or legal to capture and test all of the bats or to undertake treatment without further delay. Procrastination in seeking treatment can have a deadly outcome. The follow- ing sections provide general guidance and describe special circumstances when basic actions would be likely to mitigate the risk of disease or the severity of the infection.

\section{Humans}

Information about human rabies prevention is available from the Recommendations of the Advisory Committee on Immunization Practices (Centers for Disease Control and Prevention, 2008), which reviews rabies biologics, pre-exposure vaccination, postexposure prophylaxis, serologic testing, adverse reactions, and precautions. Additionally, current information referable to all lyssavirus laboratory services or biologics may be sought from local to international health department channels. The World Health Organization (WHO), Geneva, Switzerland, has designated various laboratories as WHO Collaborating Centers for lyssavirus reference and research.

Persons who work with rabies virus or with known or potentially infected animals can reduce their risk of infection by avoiding bites or other exposures and by receiving preexposure vaccinations followed by periodic tests for rabies antibody levels. Potentially virus-contaminated skin breaks, such as bites or scratches, should be scrubbed at once with soap and water, followed by irrigation with a virucidal agent. In these situations, tetanus prophylaxis and bacterial infection control may also be beneficial. Rapid initiation of laboratory tests on an animal source may indicate the species and virulence of lyssavirus, if present. The immediate initiation of antirabies globulin and vaccine treatments may be a lifesaving measure. However, some people have received treatment immediately and still died of rabies, having lost the race between the virus and immune-system response (Centers for Disease Control and Prevention, 2008). Nevertheless, rabies vaccines and globulin products approved for use in the USA are usually highly effective and reliable. It is important to note that tests to identify, and treatment for, exposures other than rabies or Australian bat lyssavirus may not be available or entirely satisfactory (Table 1).

\section{Wildlife Rehabilitators}

Among the many people who become wildlife rehabilitators are those who care for disabled bats. Because 1 in 10 disabled bats submitted for testing in the USA proves to have rabies, bat rehabilitators may avoid infection while handling bats by receiving inoculations of rabies vaccine. Rehabilitators may not emphasize the rabies hazard associated with bats during presentations given to school children or other audiences, because they may be motivated to care for and protect the reputation of bats and feel securely vaccinated. Complete presentations on the ecology of bats and their role in consequent rabies mortality may enhance audience appreciation of bats and educate them about the transmission of diseases carried by bats. 
Table 10. Preemptive actions for minimizing human exposures to lyssaviruses.

Potential source for exposure

Preemptive actions

\section{All bat species}

"Home deliveries" of bats by domestic cats

Vaccinate and confine cats. Control stray and feral cats.

Colonies of bats in manmade structures

Schools

Other public contact sites

Colonies of bats in caves or mine tunnels

Flying bats observed entering buildings at night

Unprovoked attacks by day-flying bats

Colonies in human-inhabited areas

Colonies in human-inhabited areas

Attacks on people

Attacks on livestock

Attacks on dogs and cats

Attacks on other bats
Prevent bat entry.

Prevent bat entry or post warning signs.

Prohibit entry to all but immunized persons with justifiable need for entry.

Avoid contact and promptly facilitate ability of flying bat to exit building. Safely collect and submit non-flying bats for testing.

Upon seeing flying bat, remain quiet and motionless until bat departs.

\section{Vampire bats}

Destroy colonies using appropriate techniques.

Educate susceptible human populations about vampire bat rabies and initiate appropriate protective measures, including vaccination and post-exposure treatment programs.

Vaccinate livestock, employ protective husbandry of livestock, and institute vampire bat control programs.

Vaccinate pets, control their outdoor movements, and house pets indoors.

Consider tropical bat bites, and other interactions between vampires and other bat species, as rabies exposures unless quickly proven otherwise.
Some rehabilitators may become embarrassed or fear consequent negative effects on their careers and on bats after they repeatedly submit rabid bats for testing. However, they need to know if a bat that has bitten them is infected so that they can receive vaccine boosters. Some rehabilitators ask friends to submit bats that bite, along with false histories, to distant laboratories for testing. Such actions may deprive the original discoverers of the bats of test results, and this knowledge is critical for the informed initiation of potentially lifesaving antirabies treatment.

\section{Cave Explorers}

Persons such as speleologists or biology students who contemplate entering bat harborages, including caves or mine tunnels, may be exposed to the health hazards associated with this activity and can take steps to decrease the risk of exposure. Applicable health hazards, precautions, and necessary preparations are detailed in a 38-page book chapter by Constantine (1988a). Topics covered include:
1. risks associated with exposure to pathogenic agents including rabies, rabies-related viruses, other viruses of bats, and histoplasmosis;

2. risks associated with exposure to bat urine, guano, and ectoparasites;

3. risks associated with oxygen deficit;

4. first aid and rescue concerning hazardous underground atmospheric gases such as ammonia, carbon dioxide, methane, carbon monoxide, and hydrogen sulfide;

5. risks associated with the deliberate contamination of bats or bat roosts with anticoagulants or poisonous gases;

6. recommended personal protective equipment; and

7. bat health problems caused by roost visitations. 
Relevant preparation prior to cave exploration can save lives later. For example, carbon dioxide, which originates from various sources within underground caverns, including the exhalations of bats, is heavier than air and displaces oxygen, so it accumulates at lower underground levels where one may sit down to rest and soon become too weak to rise. Myotis bats show extraordinary resistance to anoxia (Britton and Kline, 1945), and Brazilian free-tailed bats can live in 100 times the ammonia concentration tolerated for five minutes by a human (Studier and others, 1967; National Institute for Occupational Health Standards, 1983). Therefore, the presence of live bats does not provide assurance that the atmosphere is safe for people.

Studies have shown that inhaled rabies virus enters nerve cells (olfactory receptor cells) that extend into the nasal cavity and are freely exposed to air as it is inhaled through the nose (Constantine and others, 1972). Accordingly, the virus essentially enters the brain as one inhales air. Airborne rabies transmission in the presence of massive Brazilian free-tailed bat aggregations within bat caves has been demonstrated (Constantine, 1967b), and similar aerosol transmission of other lyssaviruses and pathogens may be likely in similarly congested bat harborages, especially in tropical and subtropical zones. Fortunately, most explorers are repelled by these environments or undertake necessary preparations to ensure their safety and survival prior to entering. Pre-exposure rabies vaccination (Centers for Disease Control and Prevention, 2008) for all explorers of caverns known to harbor bats is an essential place to begin, but it may provide little or no protection against lyssaviruses other than rabies (Hanlon and others, 2005).

\section{Animals}

Recommendations for the prevention and control of animal rabies are available in the Compendium of Animal Rabies Prevention and Control (National Association of State Public Health Veterinarians, 2008). Information includes responses to known or potential exposures of domestic pets, such as dogs, cats, and ferrets, to rabid animals.

The prompt testing of bats that expose pet mammals is indicated, and if the bat is unavailable or unsuitable for testing, then it is prudent to assume that the bat is infected and that the animal was exposed to the virus. Exposed healthy pets with up-to-date vaccinations should be revaccinated immediately, kept under the owner's control, and observed for 45 days. Immediate euthanasia of an unvaccinated pet would ensure that disease is not transmitted to other animals or to humans. If euthanasia is not the first course of action for an unvaccinated pet, then it can be placed in strict isolation for 6 months and vaccinated upon entry into isolation or 1 month before release from isolation.
Domestic cats that are permitted to hunt and that bring home their victims account for the great majority of contacts between bats and humans and resulting human lyssavirus mortality. Because cat owners and their children are the foremost victims of lyssavirus transmission from pets, the relative ease and cost effectiveness of pet management would be likely to significantly decrease the problem (Box 9).

Clearly, much remains to be learned about lyssaviruses. For example, in an experimental case, a cat developed paralysis of its rear legs 17 days after it was inoculated with rabies virus from a big brown bat. The cat underwent gradual recovery until about 2 years later, when it suffered a relapse, became debilitated, and was euthanized, whereupon the virus was recovered from the cat's central nervous system (Murphy and others, 1980). This study discloses another method by which rabies virus can survive incognito over time, supplementing known incubation periods similar to dormancy in hibernating animals during the winter.

\section{References Cited}

Ahmadu, B. and Zulu, L.N.K., 1998, Rabies in a Zambian bat: Veterinary Record, v. 143, p. 148.

Aldrovandi, U., 1599, "Ornithologie hoc est de ovibus historiae," Libre XII, v. I: Apud. I. B. Ballagambam, F. de Francisis, Bonaniae.

Allworth, A., Murray, K., and Morgan, J., 1996, A human case of encephalitis due to a lyssavirus recently identified in fruit bats: Communicable Diseases Intelligence, v. 20, p. 504.

Amengual, B., Whitby, J.E., King, A., Serra Cobo, J., and Bourhy, H., 1997, Evolution of European bat lyssaviruses: Journal of General Virology, v. 78, p. 2319-2328.

Arai, Y.T., Kuzmin, I., Kameoko, Y., and Botvinkin, A.D, 2003, New lyssavirus genotype from the lesser mouse-eared bat (Myotis blythii), Kyrghyzstan: Emerging Infectious Diseases, v. 9, p. 333-337.

Arguin, P.M., Murray-Lilliebridge, K., Miranda, M.E.G., Smith, J.S., Calaor, A.B. and Rupprecht. C.E., 2002, Serologic evidence of Lyssavirus infections among bats, the Philippines: Emerging Infectious Diseases, v. 8, p. 258-262.

Badilla, X., Pérez-Herra, V., Quirós, L., Morice, A., Jiménez, E., Sáenz, E., Salazar, F., Fernández, R., Orciari, L., Yager, P., Whitfield, S., and Rupprecht, C.E., 2003, Human rabies: a reemerging disease in Costa Rica: Emerging Infectious Diseases, v. 9, p. 721-723.

Badrane, H. and Tordo, N., 2001, Host switching in Lyssavirus history from the Chiroptera to the Carnivora orders: Journal of Virology, v. 75, p. 8096-8104.

Baer, G.M., 1975a, Bovine paralytic rabies in the vampire bat, in Baer. G.M. ed., The natural history of rabies, v. II: New York, Academic Press, p. 155-175. 
Baer, G.M., 1975b, Rabies in nonhematophagous bats, in Baer, G.M., ed., The natural history of rabies, v. II: New York, Academic Press, p. 79-97

Baer, G.M., 1991, Vampire bat and bovine paralytic rabies, in Baer, G.M., ed., The natural history of rabies ( $2^{\text {nd }}$ ed.): Boca Raton, Fla., CRC Press, p. 389-403.

Baer, G.M., and Smith, J.S., 1991, Rabies in nonhematophagous bats, in Baer, G.M., ed., The natural history of rabies ( $2^{\text {nd }}$ ed.): Boca Raton, Fla., CRC Press, p. 341-366.

Baldwin, C.L., Panciera, R.J., Morton, R.J., Cowell, A.K., and Waurzyniak, B.J., 1991, Acute tularemia in three domestic cats: Journal of the American Veterinary Medical Association, v. 199 , p. 1602-1605.

Barnhart, B., Barnhart, J., Byers, J., Nelson, D., Holloway, W., Joseph, J., Crawford, K., Acree, K., and Tierkel. E., 1976, Human rabies: Maryland Morbidity and Mortality Weekly Report, v. 29, p. 236-237.

Bell, J.F., and Moore, G.J., 1971, Susceptibility of Carnivora to rabies virus administered orally: American Journal of Epidemiology, v. 93, p. 176-182.

Bell, J.F., Moore, G.J., Raymond, G.H., and Tibbs, C.E., 1962, Characteristics of rabies in bats in Montana: American Journal of Public Health, v. 52, p. 1293-1301.

Belotto, A., Leanes, L.F., Schneider, M.C., Tasmays, H., and Correa, E., 2005, Overview of rabies in the Americas: Virus Research, v. 111, p. 5-12.

Birney, E.C., and Rising, J.D., 1967, Notes on distribution and reproduction of some bats from Kansas, with remarks on incidence of rabies: Transactions of the Kansas Academy of Science, v. 70, p. 519-524.

Blanton, J.D., Krebs, J.W., Hanlon, C.A., and Rupperecht, C.E., 2006, Rabies surveillance in the USA during 2005: Journal of the American Veterinary Medical Association, v. 229, p. 1897-1911.

Blanton, J.D., Hanlon, C.A., and Rupprecht, C.E., 2007, Rabies surveillance in the USA during 2006: Journal of the American Veterinary Medical Association, v. 231, p. 540-556.

Botvinkin, A.D., Poleschuk, E.M., Kuzmin, I.V., Borisova, T.I., Gazaryan, S.V., Yager, P., and Rupprecht, C.E., 2003, Novel Lyssaviruses isolated from bats in Russia: Emerging Infectious Diseases, v. 9, p. 1623-1625.

Botvinkin, A.D., Seinikova, O.P., Antonova, L.A., Moiseera, A.B., and Nesterenko, E.Y., 2005, Human rabies case caused by a bat in Ukraine: Rabies Bulletin Europe, v. 29, no. 3, p. 5-7.

Boulger, L.R., and Porterfield, J.S., 1958, Isolation of a virus from Nigerian fruit bats: Transactions of the Royal Society of Tropical Medicine and Hygiene, v. 52, p. 421-424.

Britton, S.W., and Kline, R.F., 1945, Age, sex, carbohydrate, adrenal cortex, and other factors in anoxia: American Journal of Physiology, v. 145, p. 190-202.
Bruyère-Masson, V., Barrat, J., Cliquet, F., Nicolas, N., Schwaab, F., Saint-Pé, M., and others., 2001, Trois nouveaux cas de rage sur sérotines communes: Malzeville, Bulletin Epidemiologique Mensuel de la Rage Animale en France, v. 31, p. 1-19.

Bruyère, V., and Janot, C., 2000, La France beintôt déclarée officiellement indemne de rage: Malzeville, Bulletin Epidemiolgique Mensuel de la Rage Animale en France, v. 30, p. 1-7.

Carini, A., 1911, Sur une grande épizootie de rage: Annales Institute Pasteur, Paris, v. 25, p. 843-846.

Carrieri, M.L., De Mattos, C.A., Carnieli, P., Jr., De Mattos, C., Favoretto, S.R., and Kotait, I., 2001, Canine and feline rabies transmitted by variant 3-Desmodus rotundus in the state of São Paulo, Brazil: International Seminar on Bats as Rabies Transmitters, December 3-6, 2001, São Paulo, Brasil, Programs and Abstracts, p. 51-52.

Centers for Disease Control and Prevention, 2008, Human rabies prevention-USA, 2008: Recommendations of the Advisory Committee on Immunization Practices (ACIP): Morbidity and Mortality Weekly Report, v. 57, no. RR-3, p. 1-28.

Christensen, E., 1946, The bats of Carlsbad Caverns: Animal Kingdom, v. 19, p. 98-102.

Cleveland, C.J., Betke, M, Federic, P, Frank, J.D., Hallam, T.G., Horn, J., López, J.D., Jr., McCracken, G.F., Medellín, R.A., Moreno-Valdez, A., Sansone, C.G., Westbrook, J.K, and Kunz, T.H., 2006, Economic value of the pest control service provided by Brazilian free-tailed bats in south-central Texas: Frontiers in Ecology and the Environment, v. 4, no. 5, p. 238-243.

Constantine, D.G., 1958, An automatic bat-collecting device: Journal of Wildlife Management, v. 22, p. 17-22.

Constantine, D.G., 1966a, Transmission experiments with bat rabies isolates: Responses of certain Carnivora to rabies virus isolated from animals infected by nonbite route: American Journal of Veterinary Research, v. 27, p.13-15.

Constantine, D.G., 1966b, Transmission experiments with bat rabies isolates: Reactions of certain Carnivora, opossum, and bats to intramuscular inoculations of rabies virus isolated from free-tailed bats: American Journal of Veterinary Research, v. 27 , p. 16-17.

Constantine, D.G., 1966c, Transmission experiments with bat rabies isolates: Bite transmission of rabies to foxes and coyote by free-tailed bats: American Journal of Veterinary Research, v. 27 , p. $20-23$.

Constantine, D.G., 1967a, Bat rabies in the southwestern USA: Public Health Reports, v. 82, p. 867-888.

Constantine, D.G., 1967b, Rabies transmission by air in bat caves: Atlanta, Ga., National Communicable Disease Center, Public Health Service Publication 1617, 51 p.

Constantine, D.G., 1970, Bats in relation to the health, welfare, and economy of man, in Wimsatt, W.A., ed., Biology of bats: v. II, p. 319-449.

Constantine, D.G., 1982a, Weather-induced mortality in migratory bats confused with rabies mortality: California Morbidity Weekly Report no. 36, p. 1. 
Constantine, D.G., 1982b, Batproofing of buildings by installation of valvelike devices in entryways: Journal of Wildlife Management, v. 46, p. 507-513.

Constantine, D.G., 1988a, Health precautions for bat researchers, in Kunz, T.H., ed., Ecological and behavioral methods for the study of bats: Washington, D.C., Smithsonian Institution Press, p. 491-528.

Constantine, D.G., 1988b, Transmission of pathogenic microorganisms by vampire bats, in Greenhall, A.M., and Schmidt, U., eds., Natural history of vampire bats: Boca Raton, Fla., CRC Press, p. 167-189.

Constantine, D.G., 1994, Rabies in Hoeprich, P.D., Jordan, M.C., and Ronald, A.R., eds., Infectious diseases ( $5^{\text {th }}$ ed.): Philadelphia, J.B. Lippincott, p. 1154-1167.

Constantine, D.G., 2003, Geographic translocation of bats: known and potential problems: Emerging Infectious Diseases, v. 9, p. 17-21.

Constantine, D.G., Emmons, R.W., and Woodie, J.D., 1972, Rabies virus in nasal mucosa of naturally infected bats: Science, v. 175 , p. $1255-1256$.

Constantine, D.G., Solomon, G.C., and Woodall, D.F., 1968b, Transmission experiments with bat rabies isolates: Responses of certain Carnivora and rodents to rabies viruses from four species of bats: American Journal of Veterinary Research, v. 29, p. 181-190.

Constantine, D.G., Tierkel, E.S., Kleckner, M.D., and Hawkins, D.M., 1968a, Rabies in New Mexico cavern bats: Public Health Reports, v. 83, p. 303-316.

Constantine, D.G., and Woodall, D.F., 1966, Transmission experiments with bat rabies isolates: Reactions of certain Carnivora, opossum, rodents, and bats to rabies virus of red bat origin when exposed by bat bite or by intramuscular inoculation: American Journal of Veterinary Research, v. 27, p. 24-32.

Crick, J., Tignor, G.H., and Moreno, K., 1982, A new isolate of Lagos bat virus from the Republic of South Africa: Transactions of the Royal Society of Tropical Medicine and Hygiene, v. 76, p. 211-213.

d'Anghiera, P.M., 1555, The decades of the newe worlde or west India, in Arber, E., ed., The first three English books on America, being chiefly translations and compilations \&c. by Richard Eden: reprinted by Birmingham, Edinburgh, 1885, p. 65-185.

Daniels, P.W., Halpin, K., Hyatt, A., and Middleton, D., 2007, Infection and disease reservoir and spillover hosts: determinants of pathogen emergence: Current Topics in Microbiology and Immunology, v. 315, p. 113-131.

De Mattos, C.A., Favi, M., Yung, V., Favoretto, S., Morais, N., Lazio-Rubio, E., Aguilar-Setiéno, A., and De Mattos, C.C., 2001, Antigenic and genetic characterization of rabies virus in the Americas: International Seminar on Bats as Rabies Transmitters, December 3-6, 2001, São Paulo, Brasil, Programs and Abstracts, p. 39-40.
De Mattos, C.C., Pape, J., Smith, J.S., and De Mattos, C.A., 2001, Bat rabies in Colorado: International Seminar on Bats as Rabies Transmitters, December 3-6, 2001, São Paulo, Brasil, Programs and Abstracts, p. 37-39.

De Oviedo y Valdes, F., 1526, "Sumario de la Historia de las Indias": reprinted by Fondo De Cultura Economica, Mexico, 1950.

Dempster, G., Grodums, E.I., Bayatpour, M., and Zbitnew, A., 1972, A human case of unsuspected rabies in Saskatchewan diagnosed by virus isolation: Canadian Journal of Public Health, v. 63 , p. $215-218$.

Familusi, J.B., Osunkoya, B.O., Moore, D.L., Kemp, G.E., and Fabiyi, A., 1972, A fatal human infection with Mokola virus: American Journal of Tropical Medicine and Hygiene, v. 21, p. 959-963.

Familusi, J.B. and Moore, D.L., 1972, Isolation of a rabies related virus from the cerebrospinal fluid of a child with 'aseptic meningitis': African Journal of Medical Science, v. 3, p. 93-96.

Favi, M., De Mattos, C.A., Yung, V., Chala, E., López, L.R., and De Mattos, C.C., 2002, First case of human rabies in Chile caused by an insectivorous bat virus variant: Emerging Infectious Diseases, v. 8, p. 79-81.

Fishbein, D.B., 1991, Rabies in humans, in Baer, G.M., ed., The natural history of rabies ( $2^{\text {nd }}$ ed.): Boca Raton, Fla., CRC Press Inc., p. 519-549.

Foggin, C.M., 1982, Atypical Mokola rabies virus in cats and a dog in Zimbabwe: Veterinary Record, v. 110, p. 338.

Foggin, C.M., 1985, Mokola virus infection in domestic cats in Zimbabwe, in Kuwert, E., Mérieux, C., Koprowki, H., and Bogel, K., eds., Rabies in the tropics: Berlin, Springer-Verlag, p. $65-70$.

Foggin, C.M., 1988, Rabies and rabies-related viruses in Zimbabwe: Historical, virological and ecological aspects: Harare, University of Zimbabwe, Ph.D dissertation.

Fooks, A.R., Finnegan, C., Johnson, N., Mansfield, K., McElhinney, L.M., 2002, Human case of EBL type 2 following exposure to bats in Argus, Scotland: Veterinary Record, v. 151, p. 679.

Fooks, A.R., McElhinney, L.M., Pounder, D.J., Finnegan, C.J., Mansfield, K., Johnson, N., Brooks, S.M., Parsons, G., White, K., and McIntyre, P.G., 2003, Isolation of a European bat lyssavirus type-2a from a fatal human case of rabies encephalitis: Journal of Medical Virology, v. 71, p. 281-289.

Franka, R., Constantine, D.G., Kuzmin, I., Velasco-Villa, A., Reeder, S.A., Streicker, D., Orciari, L.A., Wong, A.J., Blanton, J.D., and Rupprecht, C.E., 2006, A new phylogenetic lineage of rabies virus associated with western pipistrelle bats (Pipistrellus hesperus): Journal of General Virology, v. 87, p. 2309-2321.

Frantz, S.C., 1986, Batproofing structures with birdnetting checkvalves, in Salmon, T. P., ed., Proceedings of the $12^{\text {th }}$ Vertebrate Pest Conference: University of California, Davis, p. 260-268. 
Fraser, G.C., Hooper, T.P., Lunt, R.A., Gould, A.R., Gleeson, L.J., Hyatt, A.D., Russell, G.M., and Kattenbelt, J.A., 1996, Encephalitis caused by a lyssavirus in fruit bats in Australia: Emerging Infectious Diseases, v. 2, p. 327-331.

Friend, M., 2006, Disease emergence and resurgence: The wildlife-human connection: Reston, Va., U.S. Geological Survey Circular 1285, 388 p.

Gage, K.L., Dennis, D.T. , Orloski, K.A., Ettestad, P., Brown, T.L., Reynolds, P.J., Pape, W.J., Fritz, C.L., Carter, L.G., and Stein, J.D., 2000, Cases of cat-associated human plague in the western US, 1977-1998: Clinical Infectious Diseases, v. 30, p. 893-900.

Geyer, R., van Leuvan, M., Murphy, J., Damrow, T., Sastry, L., Miller, S., Goloft, M., Grendon, J., Kabayashi, J., and StehrGreen, P.A., 1997, Human rabies-Montana and Washington, 1997: Morbidity and Mortality Weekly Report, v. 46, p. 770-774.

Goswaini, A., Plun-Favreau, J., Nicoloyannis, N., Sampath, G., Siddiqui, M.N., and Zinsou, J-A., 2005, The real cost of rabies post-exposure treatments: Vaccine, v. 23, p. 2970-2976.

Greenhall, A.M., 1988, Feeding behavior, in Greenhall, A.M., and Schmidt, U., eds., Natural history of vampire bats: Boca Raton, Fla., CRC Press, p. 111-131.

Greenhall, A.M., Joermann, G., and Schmidt, U., 1983, Desmodus rotundus: Mammalian Species, v. 202, p. 1-6.

Greenhall, A.M., Joermann, G., and Schmidt, U., 1984, Diphylla ecaudata: Mammalian Species, v. 227, p. 1-3.

Greenhall, A.M. and Schutt, W.A., Jr., 1996, Diaemus youngi: Mammalian Species, v. 533, p. 1-7.

Hanlon, C.A., Kuzmin, I.V., Blanton, J.D., Weldon, W.C., Manangan, J.S., and Rupprecht, C.E., 2005, Efficacy of rabies biologics against new lyssaviruses from Eurasia: Virus Research, v. 111, p. 44-54.

Hanna, J.N., Carney, I.K., Smith, G.A., Tannenberg, A.E., Deverill, J.E., Botha, J.A., and others, 2000, Australian bat lyssavirus infection: a second human case, with a long incubation period: Medical Journal of Australia, v. 172, p. 597-599.

Hardman, M.S., Ballesca, M.A., Senseng, D.M., Spencer, S., Louden, B.M., Morehead, M.A., Anderson, P., McTaggart, B., Khan, A., Marfin, A.A., Marks, P.J., Sang, E., Fisher, M.A., Farr, R.W., Byrd, R.C., Merrill, J., Slemp, C., Lambert, F., Jr., Dodd, D. ,and Haddy, L., 1995, Human rabies-West Virginia, 1994: Morbidity and Mortality Weekly Report, v. 44, p. 86-87.

Hattwick, M.A.W., Weiss, T.T., Stechschulte, C.J., and Baer, G.M., 1972, Recovery from rabies: A case report: Annals of Internal Medicine, v. 76, p. 931-942.

Haupt, H., and Rehaag, H., 1921, Durch fledermäuse verbreitete seuchenhafte Tollwut unter Viehbeständen in Santa Catharina (Süd-Basilien): Zeitschrift für Infektionskrankheiten, v. 21, p. $104-127$.

Hentschke, J. and Hellman, E., 1975, Nachweis der tollwut bei einer fledermäuse in Berlin: Berliner and Münchener Tierarztliche Wochenschrift, v. 88, p. 92-94.
Hoofer, S.R., Van Den Bussche, R.A., and Horáček, I., 2006, Generic status of the American pipistrelles (Vespertilionidae) with description of a new genus: Journal of Mammalogy, v. 87, p. 981-992.

Humphrey, G.L., Kemp, G.E., and Wood, G., 1960, A fatal case of rabies in a woman bitten by an insectivorous bat: Public Health Reports, v. 75, p. 317-325.

Hurst, E.W., and Pawan, J.L., 1932, A further account of the Trinidad outbreak of acute rabic myelitis: histology of the experimental disease: The Journal of Pathology and Bacteriology, v. 35, p. 301-321.

Irons, J.V., Eads, R.B., Grimes, J.E., and Conklin, A., 1957, The public health importance of bats: Texas Reports on Biology and Medicine, v. 15, p. 292-298.

Johnson, H.N., 1965, Rabies virus, in Horsfall, F.L., and Tams, I., eds., Viral and rickettsial infections of man ( $4^{\text {th }}$ ed.): Philadelphia, J.B. Lippincott Co., p. 814-840.

Johnson, N., Wakeley, P.R., Brookes, S.M., and Fooks, A.R., 2006, European bat lyssavirus type 2 RNA in Myotis daubentonii: Emerging Infectious Diseases, v. 12, p. 1142-1144.

Kappeler, A, 1989, Bat rabies surveillance in Europe: Rabies Bulletin Europe, v. 13, p. 12-13.

Kerekes, B., 1999. [Rabies in] Hungary: Rabies Bulletin Europe, v. 23 , p. 6.

Khozinski, V.V., Selimov, M.A., Botvinkin, A.D., King, A., Antonova, L.A., Smekhov, A.M., Shablovskaya, E.A., Klueva, E.V., Aksenova. T.A., 1990, Rabies virus of bat origin in the USSR: Rabies Bulletin Europe, v. 14, p. 10.

King, A., and Crick, J., 1988, Rabies-related viruses in Campbell, J.B., and Charlton, K.M., eds., Rabies: Boston, Kluer Academic Publishers, p. 177-199.

King, M.A., 1993, Bats: mystic flyers and misunderstood creatures: Maine Naturalist, v. 1, p. 48-51.

Kissi, B., Tordo, N. and Bourhy, H., 1995, Genetic polymorphism in the rabies virus nucleoprotein gene: Virology, v. 206, p. 526-537.

Kotait, I., Favoretto, S.R., Carrieri, M.L., and Takoaka, N.Y., 2001, Raiva humana causada pela variante 3-Desmodus rotundus no Estado de São Paulo: International Seminar on Bats as Rabies Transmitters, December 3-6, 2001, São Paulo, Brasil, Programs and Abstracts, p. 70-71.

Krebs, J.W., Mandel, E.J., Swerdlow, D.L., and Rupprecht, C.E., 2004, Rabies surveillance in the USA during 2003: Journal of the American Veterinary Medical Association, v. 225, p. $1837-1849$.

Krebs, J.W., Mondul, A.M., Rupprecht, C.E., and Childs, J.E., 2001, Rabies surveillance in the USA during 2000: Journal of the American Veterinary Medical Association, v. 219, p. 1687-1699.

Krebs, J.W., Wheeling, J.T., and Childs, J.E., 2003, Rabies surveillance in the USA during 2002: Journal of the American Veterinary Medical Association, v. 223, p. 1736-1748. 
Kunz, T.H., 1982, Ecology of bats: New York, Plenum Press, $450 \mathrm{p}$.

Kuzmin, I.V., Hughes, G.J., Botvinkin, A.D., Orciari, L.A., and Rupprecht, C.E., 2005, Phylogenetic relationships of Irkut and West Caucasian bat viruses within the Lyssavirus genus and suggested quantitative criteria based on the $\mathrm{N}$ gene sequence for lyssavirus genotype definition: Virus Research, v. 111, p. $28-43$.

Kuzmin, I.V., Niezgoda, M., Carroll, D.S., Keeler, N., Hossain, M.J., Breiman, R.F., Ksiazek, T.G., and Rupprecht, C.E., 2006, Lyssavirus surveillance in bats, Bangladesh: Emerging Infectious Diseases, v. 12, p. 486-488.

Kuzmin, I.V., Orciari, L.A., Arai, Y.T., Smith, J.S., Hanlon, C.A., Kameoka, Y., and Rupprecht, C.E., 2003, Bat lyssaviruses (Aravan and Khujand) from Central Asia: phylogenetic relationships according to N, P, and G gene sequences: Virus Research, v. 97, p. 65-79.

Leslie, M.J., Messenger, S., Rohde, R.E., Smith, J., Cheshier, R., Hanlon, C., and Rupprecht, C.E., 2006, Bat-associated rabies virus in skunks: Emerging Infectious Diseases, v. 12, p. $1274-1277$.

Lopez, A.R., Miranda, P.P., Tejda, E.V., and Fishbein, D.B., 1992, Outbreak of human rabies in the Peruvian jungle: The Lancet, v. 339 , p. $408-412$.

Lord, R.D., Delpietro, H., and Lazaro, L., 1973, Vampiros que se alimentan de murciélagos: Buenos Aires, Physis, sec. C., v. 32, p. 225.

Lord, R.D., 1988, Control of vampire bats, in Greenhall, A.M., and Schmidt, U., eds., Natural history of vampire bats: Boca Raton, Fla., CRC Press, p. 215-226.

Lumio, J., Hillbom, M., Roine, R., Ketonen, L., Haltia, M., Valle, M., Neuvonen, E., and Lahdevirta, J., 1986, Human rabies of bat origin in Europe: The Lancet, issue 8477, p. 378.

Lumlertdacha, B., Boongird, K., Wanghongsa, S., Wacharapluesadee, S., Chanhome, L., Khawplod, P., Hemachudha, T., Kuzmin, I., and Rupprecht, C.E., 2005, Survey for bat lyssaviruses, Thailand: Emerging Infectious Diseases, v. 11, p. $232-236$.

Lyman, C.P., and Wimsatt, W.A., 1966, Temperature regulation in the vampire bat, Desmodus rotundus: Physiological Zoology, v. 39, p. 101-109.

Mackenzie, J.S., 1999, Emerging viral diseases: an Australian perspective: Emerging Infectious Diseases, v. 5, p. 1-8.

Markotter, W., Kuzmin, I., Rupprecht, C.E., Randles, J., Sabeta, C.T., Wandeler, A.I., and Nel, L.H., 2006a, Isolation of Lagos bat virus from a water mongoose: Emerging Infectious Diseases, v. 12, p. 1913-1918.

Markotter, W., Randles, J., Rupprecht, C.E., Sabeta, C.T., Taylor, P.J., Wandeler, A.I., and Nel, L.H., 2006b, Lagos bat virus, South Africa: Emerging Infectious Diseases, v. 12, p. 504-506.
Martins, F.M., Ditchfield, A.D., Meyer, D., and Morgante, J.S., 2007, Mitochondrial DNA phylogeography reveals marked population structure in the common vampire bat Desmodus rotundus (Phyllostomidae): Journal of Zoological Systematics and Evolutionary Research, v. 45, p. 372-378.

Matouch. O., 1999, [Rabies in the] Czech Republic: Rabies Bulletin Europe, v. 23, p. 4-5.

McColl, K.A., Chamberlain, T., Lunt, R.A., Newberry, K.M., Middleton, D., and Westbury, H.A., 2002, Pathogenesis studies with Australian bat lyssavirus in grey-headed flying foxes (Pteropus poliocephalus): Australian Veterinary Journal, v. 80, p. 636-641.

McColl, K.A., Tordo, N., and Aguilar Setién, A., 2000, Bat lyssavirus infections: Revue Scientifique et Technique, Office International des Épizooties, v. 19, p. 177-196.

McCracken, G.F., McCracken, M.K., and Vawter, T., 1994, Genetic structure in migratory populations of the bat $\mathrm{Ta}$ darida brasiliensis mexicana: Journal of Mammalogy, v. 75, p. 500-514.

McNab, B.K., 1973, Energetics and the distribution of vampires: Journal of Mammalogy, v. 54, p. 131-144.

Mebatsion, T., Cox, J.H., and Frost, J.W., 1992, Isolation and characterization of 115 street rabies virus isolates from Ethiopia by using monoclonal antibodies: identification of 2 isolates as Mokola and Lagos bat viruses: Journal of Infectious Diseases, v. 166, p. 972-977.

Medical College of Wisconsin. 2007. Care of rabies: Milwaukee rabies protocol, version 2.1, 58 p. Accessed February 5, 2008, at http://www.mcw.edu/display/router.asp? docid $=11655$.

Menu, H., 1984, Révision du statut de Pipistrellus subflavus (F. Cuvier, 1832), Proposition d'un taxon générique nouveau: Perimyotis nov. Gen.: Mammalia, v. 48, p. 409-416.

Meredith, C.D., Prossouw, A.P. and Kochm H.P., 1971, An unusual case of human rabies thought to be of chiropteran origin: South African Medical Journal, v. 45, p. 767-769.

Messenger, S.L., Smith, J.S., Orciari, L.A., Yager, P.A., and Rupprecht, C.E., 2003, Emerging pattern of rabies deaths and increased viral infectivity: Emerging Infectious Disease, v. 9, p. 151-154.

Messenger, S.L., Smith, J.S., and Rupprecht, C.E., 2002, Emerging epidemiology of bat-associated cryptic cases of rabies in humans in the USA: Clinical Infectious Diseases, v. 35, p. $738-747$.

Mohr, W., 1957, Die tollwut: Med. Klinik, v. 52, p. 1057-1060.

Moore, G.J., and Raymond, G.H., 1970, Prolonged incubation period of rabies in a naturally infected insectivorous bat: Journal of Wildlife Diseases, v. 6, p. 167-168.

Moreno, J.A., and Baer, G.M., 1980, Experimental rabies in the vampire bat: American Journal of Tropical Medicine and Hygiene, v. 29, p. 254-259. 
Müller, T.J., Peter, W., Schäfer, R., Bodamer, P., Wulle, U., Burrow, J., and Müller, W., 2001, Infection of a stone marten with European bat lyssavirus (EBL-1): Rabies Bulletin Europe, v. 25, p. 9-11.

Murphy, F.A., Bell, J.F., Bauer, S.P., Gardner, J.J., Moore, G.J., Harrison, A.K., and Coe, J.E., 1980, Experimental chronic rabies in the cat: Laboratory Investigation, v. 43, p. 231-241.

National Association of State Public Health Veterinarians, 2008, Compendium of animal rabies prevention and control, 2008: Morbidity and Mortality Weekly Report, v. 57, no. RR-2, p. 1-9.

National Institute for Occupational Safety and Health, 1983, NIOSH recommendations for occupational health standards: Centers for Disease Control and Prevention, Morbidity, and Mortality Weekly Report, v. 32, no. 1S, p. 1-22.

Navarro Vela, A.M., 2001, Ataques a humanos y transmisión de la rabia por murciélagos hematófagos en el Perú: International Seminar on Bats as Rabies Transmitters, December 3-6, São Paulo, Brasil, p. 54-56.

Nicolíc, M. and Jelesíc, Z., 1956, Isolation of rabies virus from insectivorous bats in Yugoslavia: World Health Organization Bulletin, v. 14, p. 801-804.

Niezgoda, M., Hanlon, C.A., and Rupprecht, C.E., 2002, Animal rabies, in Rabies, Jackson, A.C., and Wunner, W.H., eds.: San Diego, Calif., Academic Press, Elsevier Science, p. 163-218.

Osborne, T.O., and Osborne, L.Y., 1981, A shrew preying on a free-tailed bat Tadarida condylura: Bat Research News, v. 22, p. 14.

Pal, S.R., Arora, B., Chhuttani, P.N., Broor, S., Choudhury, S., Joshi, R.M., and Ray, S.D., 1980, Rabies virus infection of a flying fox bat, Pteropus poliocephalus, in Chandigarh, Northern India: Tropical and Geographical Medicine, v. 32, p. 265-267.

Pawan, J.L., 1936, Rabies in the vampire bat of Trinidad, with special reference to the clinical course and the latency of infection: Annals of Tropical Medicine and Parasitology, v. 30, p. 401-422.

Paweska, J.T., Blumberg, L.H., Liebenberg, C., Hewlett, R.H., Grobelaar, A.A., Leman, P.A., Croft, J.E., Nel, L.H., Nutt, L., and Swanepoel, R., 2006, Fatal human infection with rabiesrelated Duvenhage virus, South Africa: Emerging Infectious Diseases, v. 12, p. 1965-1967.

Pedersen, N.C., Johnson, L., and Ott, R.L., 1985, Evaluation of a feline leukemia virus vaccine for immunogenicity and efficacy: Feline Practice, v. 15, p. 7-20.

Percy, D.H., Bhatt, P.N., Tignor, G.H., and Shope, R.E., 1973, Experimental infection of dogs and monkeys with two rabies serogroup viruses, Lagos bat and Mokola (IbAn27377): Veterinary Pathology, v. 10, p. 534-549.

Pérez-Jordá, J.L., Ibáñez, C., Muñoz-Cervera, M., and Téllez, A., 1995, Lyssavirus in Eptesicus serotinus (Chiroptera: Vespertilionidae): Journal of Wildlife Diseases, v. 31, p. 372-377.
Picard-Meyer, E., Bruyère, V., Barrat, J., Tissot, E., Barrat, M.J., and Cliquet, F., 2004, Development of a hemi-nested RT-PCR method for the specific determination of European bat lyssavirus 1: comparison with other diagnostic methods: Vaccine, v. 22, p. 1921-1929.

Pitzschke, H., 1965, Tollwut bei einer breitflügel-fledermaus (Eptesicus serotinus) in Thüringen: Zentralb. Bakteriologie, Parasitenkunde, Infektions-Krankheiten und Hygiene, Abt. 1: Originale, v. 196, p. 411-415.

Porras, C., Barboza, J.J., Fuenzalida, E., Lopez-Adaros, H.L., Dias, A.M., and Furst, J., 1976, Recovery from rabies in man: Annals of Internal Medicine, v. 85, p. 44-48.

Ray, C.E., Linares, O.J., and Morgan, G.S., 1988, Paleontology, in Greenhall, A.M., and U. Schmidt, eds., Natural history of vampire bats: Boca Raton, Fla., CRC Press, p. 19-30.

Reynolds, M.G., Davidson, W.B., Curns, A.T., Conover, C.S., Huhn, G., Davis, J.P., Wegner, M., Croft, D.R., Newman, A., Obiesie, N.N., Hansen, G.R., Hays, P.L., Pontones, P., Beard, B., Teclaw, R., Howell, J.F., Braden, Z., Holman, R.C., Karem, K.L., and Damon, I.K., 2007, Spectrum of infection and risk factors for human monkeypox, USA, 2003: Emerging Infectious Diseases, v. 13, p. 1332-1339.

Ronsholt, L., Sorensen, K.J., Bruschke, G.J.M., Wellenberg, G.J., van Oirschot, J.T., Johnstone, P., Whitby, J.E., and Bourhy, H., 1998, Clinically silent rabies infection in (zoo) bats: Veterinary Record, v. 142, p. 519-520.

Rupprecht, C.E., and Childs, J.E., 1996, Feline rabies: Feline Practice, v. 24, p. 15-19.

Rupprecht, C.E., Dietzschold, B., Wunner, W.H., and Koprowski, H., 1991, Antigenic relationships of lyssaviruses, in Baer, G. M., ed., The natural history of rabies, $\left(2^{\text {nd }}\right.$ ed.): Boca Raton, Fla., CRC Press, p. 69-100.

Rupprecht, C.E., Smith, J.S., Fekadu, M., and Childs, J.E., 1995, The ascension of wildlife rabies: a cause for public health concern or intervention?: Emerging Infectious Diseases, v. 1, p. 107-114.

Rupprecht, C.E., Stöhr, K, and Meredith, C., 2001, Rabies, in Infectious diseases of wild mammals, Williams, E.S., and Barker, I.K., eds.:Ames, Iowa, Iowa State University Press, p. 3-36.

Sabeta, C.T., Markotter, W., Mohale, D.K., Shumba, W., Wandeler, A., and Nel, L.H., 2007, Mokola virus in domestic mammals, South Africa: Emerging Infectious Diseases, v. 13, p. 1371-1373.

Sadler, W.W., and Enright, J.B., 1959, Effect of metabolic level of the host upon the pathogenesis of rabies in the bat: Journal of Infectious Diseases, v. 105, p. 267-273.

Saluzzo, J.F., Rollin, P.E., Dauguet, C., Digoutte, J.P., Georges, A.J., and Sureau, P., 1984, Premier isolement du virus Mokola à partir d'un rongeur (Lophuromys sikapusi): Annales de Virologie, v. 135E, p. 56-66.

Scatterday, J.E., 1954, Bat rabies in Florida: Journal of the American Veterinary Medical Association, v. 124, p. 125. 
Schneider, N.J., Scatterday, J.E., Lewis, A.L., Jennings, W.L., Venters, H.D., and Hardy, A.V., 1957, Rabies in bats in Florida: American Journal of Public Health, v. 47, p. 983-989.

Selimov, M.A., Botvinkin, A.D., Khozinksi, V.V., Klyueva, E.V., King, A., Petrenko, L.G., Dolzhanov, P.B., Chernyavski, V.F., Kolotvina, P.K., Machitidze, C.Z., Korneeva, S.A., Barinova, L.I., Korzhenkova, A.A., 1990, Lyssavirus characterization with monoclonal antibodies on strains of certain regions of the USSR: Rabies Bulletin Europe, v. 14, p. 8-9.

Selimov, M.A., Smekhov, A.M., Antonova, L.A., Shablovskaya, E.A., King, A.A., and Kulikova, L.G., 1991, New strains of rabies-related viruses isolated from bats in the Ukraine: Acta Virologica, v. 35, p. 226-231.

Selimov, M.A., Tatarov, A.G., Antonova, L.A., Shoherbak, Y.N., Shablovskaya, E.A., Smekhov, A.M., and Mogilevsky, B.Y., 1986, To the issue of chiropteric rabic infection: Rabies Information Exchange, v. 14, p. 9-12.

Selimov, M.A., Tatorov, A.G., Botvinkin, A.D., Klueva, E.V., Kulikova, L.G., Khismatullina, N.A., 1989, Rabies-related Yuli virus: Identification with a panel of monoclonal antibodies: Acta Virologica, v. 33, p. 542-545.

Serra-Cobo, J., Amengual, B., Abellan, C., and Bourhy, H., 2002, European bat lyssavirus infection in Spanish bat populations: Emerging Infectious Diseases, v. 8, p. 413-420.

Silva, R.A., 2001, História da raiva em quirópteros no Brasil: International Seminar on Bats as Rabies Transmitters, December 3-6, 2001, São Paulo, Brasil, Programs and Abstracts, p. 34-36.

Simmons, N.B., 2005, Order Chiroptera, in Wilson, D.E., and Reeder, D.M., eds., Mammal species of the world ( $3^{\text {rd }}$ ed.): Baltimore, Johns Hopkins University Press, v. 1, p. 312-529.

Smith, J.S., 1989, Rabies virus epitopic variation: use in ecologic studies: Advances in Virus Research, v. 36, p. 215-253.

Smith, J.S., 1996, New aspects of rabies with emphasis on epidemiology, diagnosis, and prevention of the disease in the USA: Clinical Microbiology Reviews, v. 9, p. 166-176.

Smith, J.S., Messenger, S., Davis, A., Yager, P., and Rupprecht, C.E., 2001, Bat rabies: spillover infection and reservoir establishment: Twelfth Annual Rabies in the Americas Conference, November 12-16, 2001, Petersborough, Ontario, Canada, p. 46.

Smith, P.C., Lawhaswasdi, K., Vick, W.E., and Stanton, J.S., 1967, Isolation of rabies virus from fruit bats in Thailand: Nature, v. 216, p. 384.

Steele, J.H., 1969, Understanding the disease is vital to rabies control: Journal of Environmental Health, v. 31, p. 471-483.

Stoker, B., 1897. Dracula, London.

Stougaard, E., and Ammendrup, S., 1998a, Rabies in Denmark: Tübingen, Federal Republic of Germany, Rabies Bulletin Europe, v. 22 , no. 3 , p. 5 .

Stougaard, E., and Ammendrup, S., 1998b, Rabies in Denmark: Tübingen, Federal Republic of Germany, Rabies Bulletin Europe, v. 22 , no. 4 , p. 6.
Studier, E.H., Beck, L.R., and Lindeborg, R.G., 1967, Tolerance and initial metabolic response to ammonia intoxication in selected bats and rodents: Journal of Mammalogy, v. 48, p. 564-572.

Sulkin, S.E., and Greve, M.J., 1954, Human rabies caused by bat bite: Texas Journal of Medicine, v. 50, p. 620-621.

Sureau, P., Tignor, G.H., and Smith, A.L., 1980, Antigenic characterization of the Bangui strain (ANCB-672D) of Lagos bat virus: Annals of Virology, v. 131, p. 25-32.

Swanepoel, R., Leman, P.A., Burt, F.J., Zachariades, N.A., Braack, L.E.O., Ksiazek, T.G., Rollin, P.E., Zaki, S.R., and Peters, C.J., 1996, Experimental inoculation of plants and animals with Ebola virus: Emerging Infectious Diseases, v. 2, p. 321-325.

Tabel, H., Corner, A.H., Webster, W.A., and Casey, C.A., 1974, History and epizootiology of rabies in Canada: Canadian Veterinary Journal, v. 15, p. 271-281.

Takaoka, N.Y., and Omoto, T.M., 2001, Raiva humana transmitida por morcegos no Estado de São Paulo, Brasil: International Seminar on Bats as Rabies Transmitters, December 3-6, 2001, São Paulo, Brasil, Programs and Abstracts,, p. 67-69.

Tang, X., Luo, M., Zhang, S., Fooks, A.R., Hu, R., and Tu, C., 2005, Pivotal role of dogs in rabies transmission, China: Emerging Infectious Diseases, v. 11, p. 1970-1972.

Tesoro Cruz, E., Calderón Rodrígues, R., Hernández Gonzáles, R., Pérez, A., Blanco Favela, F., and Aguilar Setién, A., 2006, Rabies DNA vaccination through intradermal into ear pinnae, immunochemistry study: International Conference on Rabies in the Americas, October 15-20, 2006, Brasilia, p. 94.

Torres, S., and de Queiroz Lima, E., 1935, A raiva e sua tansmissão por morcegos hematóphagos infectado naturalmente: Rio de Janeiro, Revista do Departmento Nacional da Producção Animal, v. 2, p. 1-55.

Tudge, C., 2000, The variety of life: a survey and a celebration of all creatures that have ever lived: United Kingdom, Oxford University Press, 684 p.

Tunçman, Z.M., 1958, Les recherches du virus rabique chez les chauves-souris en Turquie Mikrobiol : Dergisi Turk, v. 11, p. 80-84.

Tuttle, M.D., 1988, America's neighborhood bats: Austin, University of Texas Press, 96 p.

Van der Poel, W.H.M., Van der Heide, R., Verstraten, E.R.A.M., Takumi, K., Lina, P.H.C., and Kramps, J.A., 2005, European bat lyssaviruses, the Netherlands: Emerging Infectious Diseases, v. 11, p. 1854-1859.

van Thiel, P.P., van den Hoek, J.A., Eftimov, F., Tepaske, R., Zaaijer, H.J., Spanjaard, L., de Boer, H.E., van Doornum, G.J., Schutten, M., Osterhaus, A., and Kager, P.A., 2008, Fatal case of human rabies (Duvenhage virus) from a bat in Kenya: the Netherlands, December 2007: Eurosurveillance, v. 13, available online: http://www.eurosurveillance.org/ViewArticle. aspx? Articleid $=8007$. 
Vargas Pino, F., 2001, Ataques a humanos y transmisión de la rabia por murciélagos hematófagos en Mexico: International Seminar on Bats as Rabies Transmitters, December 3-6, 2001, São Paulo, Brasil, Programs and Abstracts, p. 57-58.

Varughese, P., 1983, Rabies in Canada: Canada Diseases Weekly Report, v. 9, p. 137-140.

Veeraraghavan, N., 1955, A case of hydrophobia following bat bite: Pasteur Institute of Southern India, Coonoor, Scientific Report, 1954, Madras, Diocesan Press, p. 40.

Velasco Villa, A., Gómez Sierra, M., Hernández Rodrigues, G., Alvarez Solorzano, T., Vargas Pino, F., De Mattos, C.C., and De Mattos, C.A., 2001, Caracterzación antigénica de las cepas de murciélagos no hematófagos en México: International Seminar on Bats as Rabies Transmitters, December 3-6, 2001, São Paulo, Brasil, Programs and Abstracts, p. 40-41.

Venters, H.D., Hoffert, W.R., Scatterday, J.E., and Handy, A.V., 1954, Rabies in bats in Florida: American Journal of Public Health, v. 44, p. 182-185.

Warrilow, D., Harrower, B., Smith, I.L., Field, H., Taylor, R., Walker, C., and Smith, G.A., 2003, Public health surveillance for Australian bat lyssavirus in Queensland, Australia, 20012002: Emerging Infectious Diseases, v. 9, p. 262-264.

Webster, W.A., Casey, G.A., Charlton, K.M., Sayson, R.C., McLaughlin, B., and Noble, M.A., 1987, A case of human rabies in Western Canada: Canadian Journal of Public Health, v. 78 , p. $412-413$.
Willoughby R.E., Tieves K.S., Hoffman G.M., Ghanayem N.S., Amlie-Lefonf C.M., Schwabe M.J., Chusid M.J., and Rupprecht C.E., 2005, Survival after treatment of rabies with induction of coma: New England Journal of Medicine, v. 352, p. 2508-2514.

Wilson, D.E., and Reeder, D.M., eds., 2005, Mammal species of the world ( $3^{\text {rd }}$ ed.): Baltimore, Johns Hopkins University Press, 2142 pages.

World Health Organization Collaborating Centre for Rabies Surveillance and Research, 1986, Table of bat rabies cases 1954- 1986: Tübingen, Germany, Rabies Bulletin Europe, v. 10 , p. $12-14$.

World Health Organization Collaborating Centre for Rabies Surveillance and Research, 1988, Table of bat rabies cases 1954-1988: Tübingen, Germany, Rabies Bulletin Europe, v. 12, p. $18-19$.

World Health Organization Collaborating Centre for Rabies Surveillance and Research, 1999, Rabies in individual countries: Tübingen, Germany, Rabies Bulletin Europe, v. 23, p. 4-8.

Yamamoto, J.K., Hansen, H., Ho, E.W., Morishita, T.Y., Okuda, T., Sawa, T.R., Nakamura, R.M., Pedersen, N.C., 1989, Epidemiologic and clinical aspects of feline immunodeficiency virus infection in cats from the continental USA and Canada and possible mode of transmission: Journal of the American Veterinary Medical Association, v. 194, p. 213-238. 


\section{Glossary}

A

active immunity The internal capability of the body to combat disease agents; develops either following infection by a disease agent or by vaccination as the immune system responds by producing antibodies against the agent. (See also passive immunity.)

African bats Bat species native to the African continent.

Americas Lands of the New World (Western hemisphere), consisting of North, Central, and South America and their associated islands.

amphibians A group of poikilothermic ("cold-blooded"), scaleless, vertebrate animals that usually begin life in the water as gill-breathing tadpoles and that later develop lungs and spend part of their time on land.

amplification host A host in which infectious agents multiply to high concentrations, (See also intermediate host, reservoir host.)

anoxia A condition characterized by the absence of oxygen. For living organisms, this condition involves the absence of a supply of oxygen to an organ or a tissue.

antibody A protein formed in the body of a vertebrate that is used by the immune system to identify and neutralize the effects of foreign invading proteins, called antigens, such as bacteria and viruses. (See also maternal antibody, passive immunity.)

arthropods The largest group of animals, comprising more than 80 percent of described living animal species, that includes insects, spiders, and crustaceans. Arthropods are covered by a hard exoskeleton and are characterized by a segmented body, jointed legs, and many pairs of limbs.

\section{B}

bats Mammals in which the forelimbs have developed as wings, making them the only mammals in the world naturally capable of flight. There are estimated to be about 1,100 species of bats worldwide, accounting for about 20 percent of all mammal species. (See also African bat.)

insectivorous bats Those that primarily feed on insects while in flight fruit-eating bats Those that feed almost entirely on fruit and on some green vegetation. (See also frugivorous.)

true vampire bats Those that feed on blood obtained from animals and humans.

biological transmission Disease transfer requiring an amplification host (often an arthropod) for development or multiplication of the disease agent (or both) necessary for infection of another host.

biologics A range of pharmaceutical products including vaccines, blood components, and therapeutic proteins used to treat a variety of medical conditions.

birds Warm-blooded vertebrates with wings and feathers, although the wings are poorly developed in some species and they are flightless. Birds belong to the taxonomic class Aves.

blood serum The pale fluid that remains after blood has clotted.

burro A term used in the Western USA to refer to a donkey.

\section{C}

carnivores Animals whose diet consists mainly of meat.

clinical signs Readily observable indications of a disease or injury.

conspecific An organism of the same species.

cornea The transparent covering on the front of the eye.

D

dewlap A flap of skin containing stored fat that hangs beneath the lower jaw of animals including mammals, birds, reptiles, or amphibians.

DNA (deoxyribonucleic acid) A nucleic acid found mainly in the chromosomes that contains the hereditary information of organisms and some viruses.

donkey A pony-sized domesticated member of the horse family. 


\section{$\mathbf{E}$}

Ebola The common name for the virus that causes the fatal disease Ebola hemorrhagic fever. Ebola has caused a number of serious and highly publicized outbreaks since its discovery in Africa in 1976.

exsanguination The fatal process of total blood loss, or "bleeding to death."

\section{$\mathbf{F}$}

flaccid paralysis Paralysis with a loss of muscle tone.

flying fox Large, fruit-eating bats with a foxlike appearance of the head. These bats are also commonly referred to as "fruit bats."

frugivorous An animal that feeds primarily or exclusively on fruit.

furious rabies A manifestation of rabies that in animals is characterized by periods of aggressive behavior towards inanimate objects and towards other animals and humans.

\section{G}

genet Small, largely nocturnal catlike carnivores with short legs, long bodies and tails, rounded ears, and pointed snouts; found in forests, savannahs, and grasslands of Africa and parts of Europe.

genotype The genetic makeup of a biological organism.

genus A taxonomic group of similar species; similar genera are grouped into families.

guano A term used here for the excrement of bats, but also including the manure of sea birds used as a fertilizer and other manure resembling the appearance of such excrements.

\section{H}

harp trap A large boxlike device effective for catching bats. A series of vertical wires extend upwards from the collection chamber. Bats in flight collide with the wires and then fall into the collection chamber below.

heterothermous An animal with the capability for regulating its internal body temperature above that of its environment during periods of activity. When the animal is at rest, however, its body temperature drops to that of its surrounding environment. (See also homoiothermous, poikilothermous.) hibernation A state of inactivity in animals characterized by a lower body temperature, slower breathing, and a reduced metabolic rate. Hibernation allows animals to conserve energy during the winter when food may be unavailable.

histoplasmosis A potentially fatal disease that primarily effects the lungs and is caused by the fungus Histoplasma capsulatum.

Spores of $H$. capsulatum, which are found in soil contaminated with bat or bird droppings, can become airborne when the contaminated soil is disturbed. Inhaling the spores can result in infection.

homoiothermous An animal with a body temperature that is constant and largely independent of the temperature of its surroundings. (See also heterothermous, poikilothermous.)

host An organism that harbors or nourishes microbes, viruses, and parasites. (See also intermediate host, reservoir host.)

hyperimmune sera Typically, blood serum with an especially high concentration of antibodies produced by repeated antigen injections into healthy donor hosts.

hypothermia A condition in which an animal's core body temperature drops below that required for normal physiological functions.

I

incubation period The time from the initiation of infection until the first recognized clinical signs.

insectivorous An animal that feeds primarily on insects.

intermediate host An organism in or on which a parasite develops for part of its life cycle. (See also host, reservoir host.)

\section{J}

jaguar The largest wild cat of the Americas. Typically found in thick wooded and arid shrubby environments from border areas of Texas and Arizona south to about $40^{\circ}$ South latitude. A fierce predator, the jaguar is distinctly marked by black spots within the center of the rosettes that pattern its hide. 
lyssavirus A genus of viruses of the family Rhabdoviridae.

\section{M}

mammals Warm-blooded vertebrate animals that possess hair during some part of their life and suckle their young.

maternal antibody An antibody transferred from a mammalian mother through the placenta into her fetus. (See also passive immunity.)

mechanical transmission Disease transfer involving contact with surfaces contaminated by pathogens. Mechanical transmission from bites, scratches, contact with inanimate objects, and other means allows disease-causing levels of the pathogen to enter the host.

Megachiroptera One of two taxonomic suborders of bats (the Chiroptera) and comprised of a single family, the Pteropodidae, or Old World fruit bats.

melancholia A nonspecific depression characterized by low levels of enthusiasm and low levels of eagerness for physical activity.

Microchiroptera The taxonomic suborder of bats (the Chiroptera) that contains all bats other than the fruit bats (flying foxes). It should be noted that some fruit bats (Megachiroptera) are smaller in size than some bat species within the Microchiroptera.

mites A medically important group of arthropods of the taxonomic order Acarina, but excluding ticks. These external parasites, closely related to spiders, cause a variety of infestations, often of the skin of humans and animals, and of the hair and feathers of animals.

monkeypox A viral disease related to smallpox that is transmissible between animals and humans and that primarily occurs in central and western Africa. The exotic pet trade resulted in the 2003 introduction of this disease into the USA.

mucosal surfaces Moist surfaces of orifices and internal parts of the body that cover, protect, and provide secretory and absorptive functions.

mule The usually sterile offspring of a male donkey and a female horse.

\section{$\mathbf{N}$}

0

omnivorous An animal with a diet of both plants and animals.

$\mathbf{P}$

paralytic rabies A manifestation of rabies that in animals is characterized by signs of posterior paralysis and that generally lacks the violent symptoms of furious rabies.

passive immunity Immunity achieved following the receipt of antibodies from an immune donor. Protection by passive immunity lasts for a relatively short time. For example, in humans, antibodies passed from mother to fetus confer passive immunity to the baby for the first 4 to 6 months of life. (See also active immunity.)

pathogen Typically, a mircoorganism capable of inducing disease, but broadly includes all disease-inducing agents.

placenta A temporary organ rich in blood vessels that transfers oxygen and nutrients from the mother to the fetus and that permits the release of carbon dioxide and waste products from the fetus. The placenta is expelled during the birth process.

plague An infectious disease of animals and humans caused by the bacterium Yersinia pestis. Although millions of people in Europe died from plague during the Middle Ages, modern antibiotics provide effective treatment of this disease when administered promptly following development of symptoms.

poikilothermous An animal with a body temperature that varies with the temperature of its environment. (See also heterothermous, homoiothermous.)

poultry A general term for farmed domestic birds, including chickens, turkeys, ducks, and geese.

prevalence The total number of cases of a disease in a population at a given time.

prodromal Early nonspecific symptoms, such as fever, headache, malaise, and nausea, indicating the start of a disease before specific symptoms occur.

putative Assumed or accepted as true. 
$\mathbf{0}$

$\mathbf{R}$

reptiles A group of poikilothermic

("cold-blooded"), air-breathing, verte-

brate animals with scaled bodies. (See also

poikilothermous.)

reservoir host An organism that maintains a disease agent in nature and that provides a source of infection to susceptible hosts. (See also intermediate host.)

\section{S}

salivary gland A gland that produces saliva.

sanguivorous An animal that feeds on blood; for example, certain bats, leeches, and insects.

serial transmission The sequential spreading of a disease agent among multiple susceptible hosts. (See also host.)

skunk Several species of carnivores within the family Mephitidae; specifically, the striped, hooded, spotted, and hog-nosed skunk.

species A population of organisms whose members are able to breed among themselves and produce fertile offspring. More precise determinations of species are based on similarity of DNA. (See also strain, variant.)

speleologist A person who explores caves. strain A genetically or biochemically distinguishable subtype of a microorganism.

symptomatic Showing symptoms or signs of a disease or injury.

\section{T}

taxonomy The systematic principles and procedures of grouping and arranging organisms into a hierarchical order.

temperate zone Latitudes of the globe that lie between the tropics and the polar circles that exhibit seasonal temperature patterns.

torpid Dormant, as observed for hibernating animals. (See also hibernation.)

tropical Geographically, the zone on either side of the equator, bounded by the Tropic of Cancer (23 $27^{\prime}$ North latitude) and the Tropic of Capricorn (23⒉ $7^{\prime}$ South latitude); climatically hot and humid for the majority of the year.
U

umbilical cord A tube that connects a developing embryo or fetus to the placenta.

V

vaccine A biological preparation containing an antigen, a molecule that stimulates the immune system, that is used to establish immunity to a disease.

variant A group of organisms of the same species that exhibit subtle yet characterizable differences from one another.

vector An animal, including insects, that carries a disease-causing organism from an infected to a healthy animal or plant, thus causing the latter to become infected.

vertebrates All animals that have spinal columns: mammals, birds, reptiles, amphibians, and fishes.

virulence The degree or ability of a pathogenic organism to cause disease. (See also pathogen.)

virus A microscopic infectious agent that can cause a disease, such as rabies in animals and potato virus in potato, tomato, and tobacco plants. A virus can reproduce only by invading living cells, and it exists outside of living cells as an inactive particle.

\section{W}

$\mathbf{X}$

\section{Y}

Z

Zebu An Asian ox, domesticated and differentiated into many breeds, and physically distinguished from European cattle by the presence of a large fleshy hump over the shoulders, a loose skin prolonged in a dewlap and folds under the belly, and large droopy ears. 


\section{Appendix A. Bat Species Reported Infected with Rabies in the USA from 1953 to 2007}

\begin{tabular}{ll}
\hline Bat species (common name) & Family \\
\hline Big brown bat & Vespertilionidae \\
\hline Big free-tailed bat & Molossidae \\
\hline Brazilian free-tailed bat & Molossidae \\
\hline California leaf-nosed bat & Phyllostomidae \\
\hline California myotis & Vespertilionidae \\
\hline Canyon bat & Vespertilionidae \\
\hline Cave myotis & Vespertilionidae \\
\hline Eastern red bat & Vespertilionidae \\
\hline Evening bat & Vespertilionidae \\
\hline Fringed myotis & Vespertilionidae \\
\hline Gray myotis & Vespertilionidae \\
\hline Greater bonneted bat & Molossidae \\
\hline Hoary bat & Vespertilionidae \\
\hline Keen's myotis & Vespertilionidae \\
\hline Little brown myotis & Vespertilionidae \\
\hline
\end{tabular}

\begin{tabular}{ll}
\hline Bat species (common name) & Family \\
\hline Long-legged myotis & Vespertilionidae \\
\hline Northern myotis & Vespertilionidae \\
\hline Northern yellow bat & Vespertilionidae \\
\hline Pallid bat & Vespertilionidae \\
\hline Peter's ghost-faced bat & Mormoopidae \\
\hline Pocketed free-tailed bat & Molossidae \\
\hline Seminole bat & Vespertilionidae \\
\hline Silver-haired bat & Vespertilionidae \\
\hline Southeastern myotis & Vespertilionidae \\
\hline Southern yellow bat & Vespertilionidae \\
\hline Spotted bat & Vespertilionidae \\
\hline Townsend's big-eared bat & Vespertilionidae \\
\hline Tricolored bat & Vespertilionidae \\
\hline Western red bat & Vespertilionidae \\
\hline Western small-footed myotis & Vespertilionidae \\
\hline Western yellow bat & Vespertilionidae \\
\hline Yuma myotis & Vespertilionidae \\
\hline
\end{tabular}




\section{Appendix B. Bat Species Reported Infected with Rabies in the Americas through 2006}

\begin{tabular}{|c|c|c|}
\hline Bat species (common name) & Family & Country where infection was identified \\
\hline Argentine brown bat & Vespertilionidae & Brazil \\
\hline Big brown bat & Vespertilionidae & Canada, Cuba, Mexico, United States \\
\hline Big free-tailed bat & Molossidae & Brazil, Mexico, United States \\
\hline Big-eared brown bat & Vespertilionidae & Chile \\
\hline Black bonneted bat & Molossidae & Argentina, Brazil \\
\hline Black mastiff bat & Molossidae & Brazil, Mexico, Venezuela \\
\hline Black myotis & Vespertilionidae & Argentina, Belize, Brazil, Panama, Peru \\
\hline Black-winged little yellow bat & Vespertilionidae & Mexico \\
\hline Brazilian brown bat & Vespertilionidae & Colombia \\
\hline Brazilian free-tailed bat & Molossidae & Argentina, Brazil, Chile, Mexico, United States \\
\hline Broad-eared free-tailed bat & Molossidae & Brazil, Mexico \\
\hline Brown fruit-eating bat & Phyllostomidae & Peru \\
\hline Brown mastiff bat & Molossidae & Brazil \\
\hline Bulldog bat & Noctilionidae & Panama \\
\hline California leaf-nosed bat & Phyllostomidae & United States \\
\hline California myotis & Vespertilionidae & Canada, United States \\
\hline Canyon bat & Vespertilionidae & United States \\
\hline Cave myotis & Vespertilionidae & Mexico, United States \\
\hline Chilean myotis & Vespertilionidae & Chile \\
\hline Cinnamon dog-faced bat & Molossidae & Brazil \\
\hline Cinnamon myotis & Vespertilionidae & Belize, Guatemala \\
\hline Common mustached bat & Mormoopidae & Mexico, Trinidad \\
\hline Common sword-nosed bat & Phyllostomidae & Brazil \\
\hline Common tent-making bat & Phyllostomidae & Panama \\
\hline Common vampire bat & Phyllostomidae & $\begin{array}{l}\text { Argentina, Belize, Bolivia, Brazil, Colombia, Costa Rica, } \\
\text { Ecuador, E1 Salvador, Guatemala, Mexico, Nicaragua, } \\
\text { Paraguay, Peru, Trinidad, Venezuela }\end{array}$ \\
\hline Davy's naked-backed bat & Mormoopidae & Mexico, Trinidad \\
\hline Diminutive serotine & Vespertilionidae & Brazil \\
\hline Eastern red bat & Vespertilionidae & Canada, Mexico, United States \\
\hline Evening bat & Vespertilionidae & United States \\
\hline Fringed myotis & Vespertilionidae & United States \\
\hline Fringe-lipped bat & Phyllostomidae & Brazil \\
\hline Fruit-eating bat & Phyllostomidae & Mexico, Peru \\
\hline
\end{tabular}




\begin{tabular}{|c|c|c|}
\hline Bat species (common name) & Family & Country where infection was identified \\
\hline Geoffroy's tailless bat & Phyllostomidae & Brazil \\
\hline Gray myotis & Vespertilionidae & United States \\
\hline Gray short-tailed bat & Phyllostomidae & Mexico \\
\hline Great fruit-eating bat & Phyllostomidae & Belize, Bolivia, Brazil, Guatemala, Mexico, Peru, Trinidad \\
\hline Great stripe-faced bat & Phyllostomidae & Brazil \\
\hline Greater bonneted bat & Molossidae & Brazil, United States \\
\hline Greater bulldog bat & Noctilionidae & Mexico \\
\hline Greater spear-nosed bat & Phyllostomidae & Brazil, Peru \\
\hline Hairy-legged vampire bat & Phyllostomidae & Brazil, Mexico \\
\hline Hoary bat & Vespertilionidae & Argentina, Brazil, Canada, Mexico, United States \\
\hline Jamaican fruit-eating bat & Phyllostomidae & Belize, Bolivia, Brazil, Grenada, Mexico, Panama, Trinidad \\
\hline Keen's myotis & Vespertilionidae & Canada, United States \\
\hline Lesser long-nosed bat & Phyllostomidae & Mexico \\
\hline Lesser spear-nosed bat & Phyllostomidae & Peru \\
\hline Little big-eared bat & Phyllostomidae & Brazil, Panama, Peru \\
\hline Little brown myotis & Vespertilionidae & Canada, United States \\
\hline Little yellow-shouldered bat & Phyllostomidae & Brazil \\
\hline Long-eared myotis & Vespertilionidae & Canada, United States \\
\hline Long-legged myotis & Vespertilionidae & United States \\
\hline Mexican long-nosed bat & Phyllostomidae & Mexico \\
\hline Northern ghost bat & Emballonuridae & Trinidad \\
\hline Northern myotis & Vespertilionidae & Canada, United States \\
\hline Northern yellow bat & Vespertilionidae & Mexico, United States \\
\hline Pale spear-nosed bat & Phyllostomidae & Belize, Guatemala, Mexico \\
\hline Pallas' long-tongued bat & Phyllostomidae & Mexico, Peru \\
\hline Pallas' mastiff bat & Molossidae & Belize, Brazil, Colombia, Panama, Peru, Trinidad \\
\hline Pallid bat & Vespertilionidae & Mexico, United States \\
\hline Patagonian dwarf bonneted bat & Molossidae & Argentina \\
\hline Peters' ghost-faced bat & Mormoopidae & Mexico, United States \\
\hline Pocketed free-tailed bat & Molossidae & United States \\
\hline Pygmy round-eared bat & Phyllostomidae & Brazil \\
\hline Seba's short-tailed bat & Phyllostomidae & Colombia, Peru, Trinidad \\
\hline Seminole bat & Vespertilionidae & Mexico, United States \\
\hline
\end{tabular}




\begin{tabular}{|c|c|c|}
\hline Bat species (common name) & Family & Country where infection was identified \\
\hline Silver-haired bat & Vespertilionidae & Canada, United States \\
\hline Silver-tipped myotis & Vespertilionidae & Brazil \\
\hline Sinaloan mastiff bat & Molossidae & Belize, Brazil, Guatemala, Honduras \\
\hline Small big-eared brown bat & Vespertilionidae & Argentina \\
\hline Southeastern myotis & Vespertilionidae & United States \\
\hline Southern dog-faced bat & Molossidae & Panama \\
\hline Southern yellow bat & Vespertilionidae & Brazil, Mexico, Paraguay, United States \\
\hline Spotted bat & Vespertilionidae & Canada, United States \\
\hline Tailed tailless bat & Phyllostomidae & Brazil \\
\hline Thomas' mastiff bat & Molossidae & Panama \\
\hline Townsend's big-eared bat & Vespertilionidae & United States \\
\hline Tricolored bat & Vespertilionidae & Canada, Mexico, United States \\
\hline Tropical big-eared brown bat & Vespertilionidae & Brazil \\
\hline Wagner's bonneted bat & Molossidae & Cuba \\
\hline Wagner's mustached bat & Mormoopidae & Mexico \\
\hline Waterhouse's leaf-nosed bat & Phyllostomidae & Mexico \\
\hline Western red bat & Vespertilionidae & Argentina, Brazil, Chile, United States \\
\hline Western small-footed myotis & Vespertilionidae & Canada, United States \\
\hline Western yellow bat & Vespertilionidae & United States \\
\hline White-lined broad-nosed bat & Phyllostomidae & Peru \\
\hline White-winged vampire bat & Phyllostomidae & Brazil, Mexico, Trinidad \\
\hline Woolly false vampire bat & Phyllostomidae & Brazil \\
\hline Yuma myotis & Vespertilionidae & Canada, United States \\
\hline
\end{tabular}




\section{Appendix C. Common and Scientific Names for Species Cited}

[Common and scientific names from Wilson and Reeder (2005)]

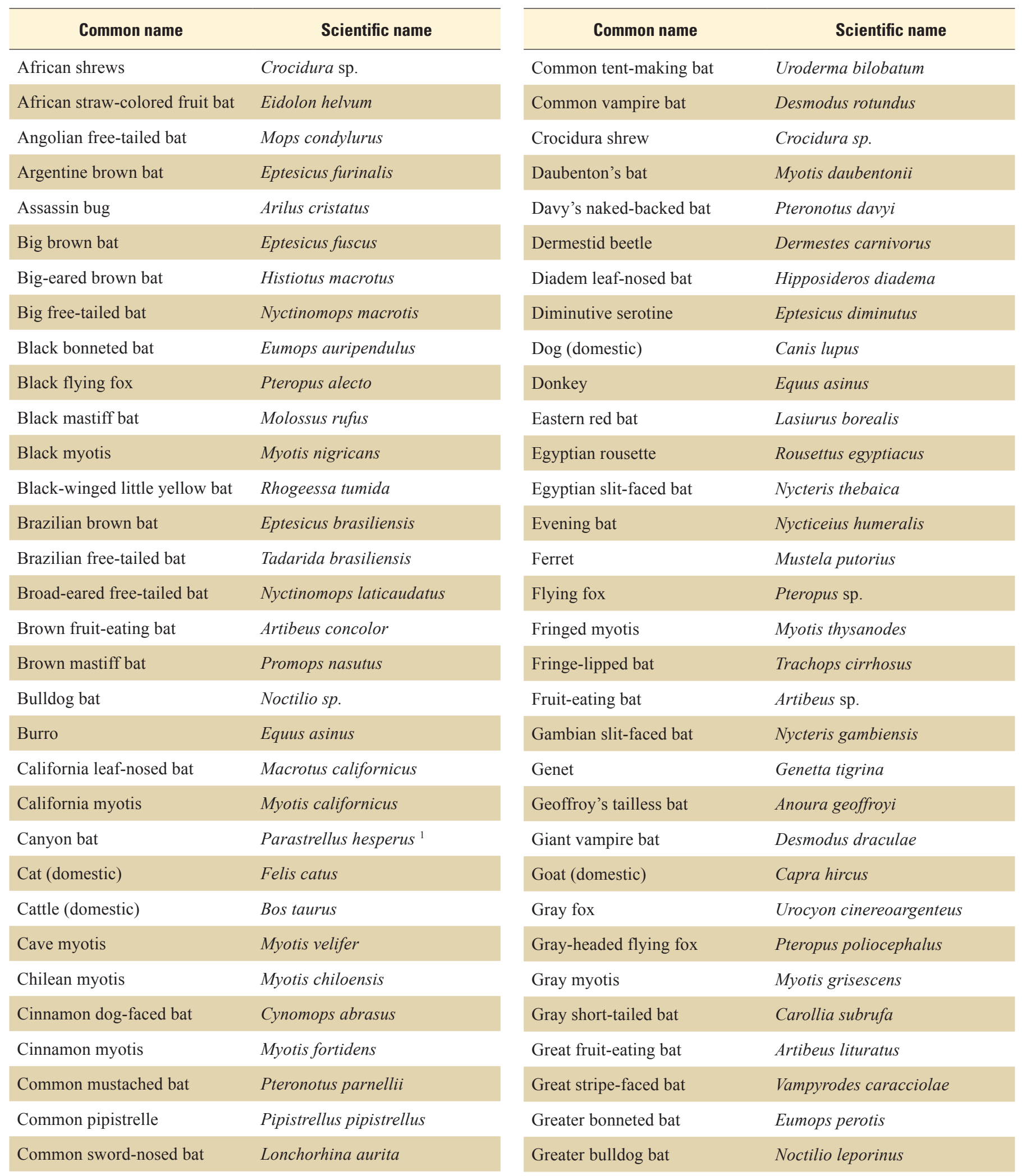




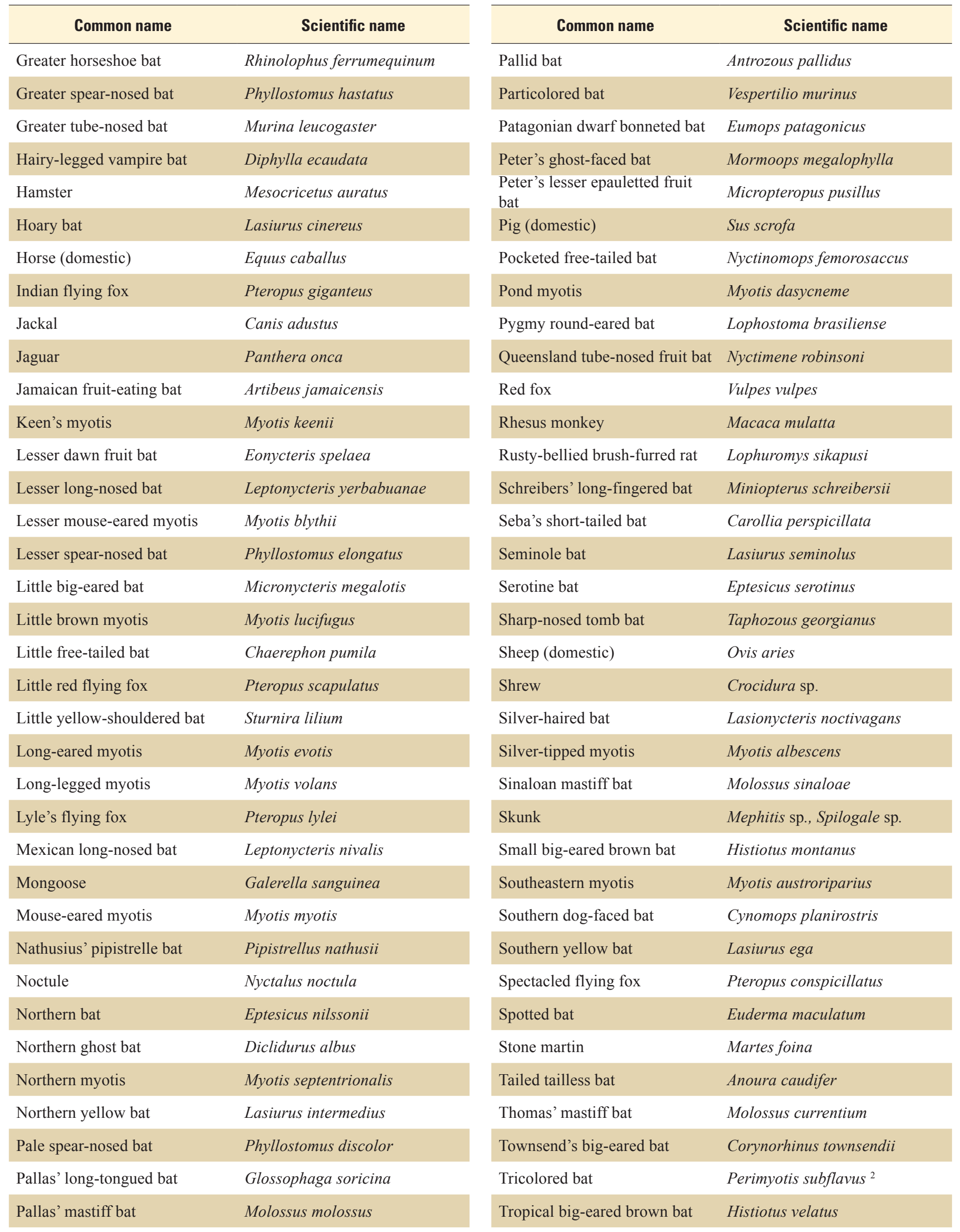




\begin{tabular}{ll}
\hline \multicolumn{1}{c}{ Common name } & \multicolumn{1}{c}{ Scientific name } \\
\hline Wagner's bonneted bat & Eumops glaucinus \\
\hline Wagner's mustached bat & Pteronotus personatus \\
\hline Wahlberg's epauletted fruit bat & Epomophorus wahlbergi \\
\hline Waterhouse's leaf-nosed bat & Macrotus waterhousii \\
\hline Water mongoose & Atilax paludinosusis \\
\hline Western red bat & Lasiurus blossevillii \\
\hline Western small-footed myotis & Myotis ciliolabrum \\
\hline Western yellow bat & Lasiurus xanthinus \\
\hline
\end{tabular}

\begin{tabular}{ll}
\hline \multicolumn{1}{c}{ Common name } & \multicolumn{1}{c}{ Scientific name } \\
\hline Whiskered myotis & Myotis mystacinus \\
\hline White-lined broad-nosed bat & Platyrrhinus lineatus \\
\hline White-winged vampire bat & Diaemus youngi \\
\hline Woolly false vampire bat & Chrotopterus auritus \\
\hline Yellow-bellied sheathtail bat & Saccolaimus flaviventris \\
\hline Yuma myotis & Myotis yumanensis \\
\hline Zebu & Bos indicus \\
\hline
\end{tabular}

${ }^{1}$ The canyon bat was formerly the Western pipistrelle (Pipistrellus hesperus). The species has been reclassified as the only member of the genus Parastrellus (Hoofer and others, 2006) and is currently referred to as the canyon bat.

${ }^{2}$ The tricolored bat was formerly the Eastern pipistrelle (Pipistrellus subflavus). This species has been reclassified as the only member of the genus Perimyotis (Menu, 1984; Hoofer and others, 2006) and is currently referred to as the tricolored bat. 


\section{Appendix D. Lyssavirus Infections in Bats Reported in Africa, Asia, Australia, and Europe}

\begin{tabular}{|c|c|c|c|c|c|}
\hline Common name & Family & Food habits & Geographic location & Lyssavirus species & Citation \\
\hline $\begin{array}{l}\text { African straw-colored } \\
\text { fruit bat }\end{array}$ & Pteropodidae & Frugivorous & $\begin{array}{l}\text { Nigeria } \\
\text { Senegal }\end{array}$ & $\begin{array}{l}\text { Lagos } \\
\text { Lagos }\end{array}$ & $\begin{array}{l}\text { Boulger and Porterfield, } 1958 \\
\text { Markotter and others, } 2006 a\end{array}$ \\
\hline Black flying fox & Pteropodidae & Frugivorous & Australia & Australian & Warrilow and others, 2003 \\
\hline Common pipistrelle & Vespertilionidae & Insectivorous & $\begin{array}{l}\text { Germany } \\
\text { France }\end{array}$ & $\begin{array}{l}\text { Unknown } \\
\text { Unknown }\end{array}$ & $\begin{array}{l}\text { WHO CCRSR, }{ }^{1} 1988 \\
\text { Bruyère and Janot, } 2000\end{array}$ \\
\hline Daubenton's bat & Vespertilionidae & Insectivorous & $\begin{array}{l}\text { Denmark } \\
\text { Germany } \\
\text { Switzerland } \\
\text { United Kingdom }\end{array}$ & $\begin{array}{l}\text { EBL-2 } \\
\text { EBL-2 } \\
\text { EBL-2 } \\
\text { EBL-2 }\end{array}$ & $\begin{array}{l}\text { Johnson and others, } 2006 \\
\text { Johnson and others, } 2006 \\
\text { Johnson and others, } 2006 \\
\text { Johnson and others, } 2006\end{array}$ \\
\hline Egyptian rousette & Pteropodidae & Frugivorous & Egypt & Lagos & Markotter and others, $2006 \mathrm{~b}$ \\
\hline Gray-headed flying fox & Pteropodidae & Frugivorous & Australia & Australian & Warrilow and others, 2003 \\
\hline Greater horseshoe bat & Rhinolophidae & Insectivorous & Turkey & Unknown & Tunçman, 1958 \\
\hline Greater tube-nosed bat & Vespertilionidae & Insectivorous & Russia & Irkut & Botvinkin and others, 2003 \\
\hline Indian flying fox & Pteropodidae & Frugivorous & India & Unknown & Pal and others, 1980 \\
\hline $\begin{array}{l}\text { Lesser mouse-eared } \\
\text { myotis }\end{array}$ & Vespertilionidae & Insectivorous & Kyrghyzstan & Aravan & Botvinkin and others, 2003 \\
\hline Little red flying fox & Pteropodidae & Frugivorous & Australia & Australian & Warrilow and others, 2003 \\
\hline
\end{tabular}




\begin{tabular}{|c|c|c|c|c|c|}
\hline Common name & Family & Food habits & Geographic location & Lyssavirus species & Citation \\
\hline Northern bat & Vespertilionidae & Insectivorous & Russia & Unknown & $\begin{array}{l}\text { Khozinski and others, } 1990 \text {; } \\
\text { Selimov and others, } 1990\end{array}$ \\
\hline Particolored bat & Vespertilionidae & Insectivorous & Ukraine & EBL-1 & Kappeler, 1989 \\
\hline $\begin{array}{l}\text { Peter's lesser } \\
\text { epauletted fruit bat }\end{array}$ & Pteropodidae & Frugivorous & $\begin{array}{l}\text { Central African } \\
\text { Republic }\end{array}$ & Lagos & Sureau and others, 1980 \\
\hline Pond myotis & Vespertilionidae & Insectivorous & $\begin{array}{l}\text { Denmark } \\
\text { Netherlands }\end{array}$ & $\begin{array}{l}\text { EBL-2 } \\
\text { EBL-2 }\end{array}$ & $\begin{array}{l}\text { WHO CCRSR, }{ }^{1} 1986 \\
\text { Van der Poel and others, } 2003\end{array}$ \\
\hline $\begin{array}{l}\text { Schreiber's } \\
\text { long-fingered bat }\end{array}$ & Vespertilionidae & Insectivorous & Russia & WCBV & Botvinkin and others, 2003 \\
\hline Serotine bat & Vespertilionidae & Insectivorous & $\begin{array}{l}\text { Russia } \\
\text { Czech Republic. } \\
\text { Denmark } \\
\text { France } \\
\text { Germany } \\
\text { Hungary } \\
\text { Netherlands } \\
\text { Poland } \\
\text { Spain } \\
\text { Ukraine }\end{array}$ & $\begin{array}{l}\text { Unknown } \\
\text { Unknown } \\
\text { EBL-1 } \\
\text { EBL-1 } \\
\text { EBL-1 } \\
\text { Unknown } \\
\text { EBL-1 } \\
\text { EBL-1 } \\
\text { EBL-1 } \\
\text { Unknown }\end{array}$ & $\begin{array}{l}\text { Amengual and others, } 1997 \\
\text { Matouch, } 1999 \\
\text { Amengual and others, } 1997 \\
\text { Amengual and others, } 1997 \\
\text { Amengual and others, } 1997 \\
\text { Kerekes, } 1999 \\
\text { Amengual and others, } 1997 \\
\text { Amengual and others, } 1997 \\
\text { Amengual and others, } 1997 \\
\text { Selimov and others, } 1986\end{array}$ \\
\hline Spectacled flying fox & Pteropodidae & Frugivorous & Australia & Australian & Warrilow and others, 2003 \\
\hline $\begin{array}{l}\text { Wahlberg's epauletted } \\
\text { fruit bat }\end{array}$ & Pteropodidae & Frugivorous & South Africa & Lagos & Crick and others, 1982 \\
\hline Whiskered myotis & Vespertilionidae & Insectivorous & Tajikistan & Khujand & Kuzmin and others, 2003 \\
\hline
\end{tabular}

\footnotetext{
${ }^{1}$ World Health Organization Collaborating Centre for Rabies Surveillance and Research, Tübingen, Germany.
} 


\section{Appendix E. Course of Bat Lyssavirus Infections in Humans}

\section{Case 1. Exposure in South America (Hurst and Pawan, 1932)}

The victim was awakened by being bitten on a toe of the left foot, whereupon a vampire bat was observed flying away from the foot.

Day 1 of symptoms, 27 days later: The victim felt a burning sensation and cramps in the left foot and was unable to flex the foot at the ankle. The left foot was also numb to touch. The symptoms later spread to the victim's leg, which became weak.

Day 3: The victim's right foot became numb. Symptoms grew worse over several days.

Day 7: The victim had flaccid paralysis and numbness in the left leg and right foot and numbness over the trunk to the level of eighth to ninth rib. The victim was unable to pass urine freely and had been constipated for the past 8 days. The victim could answer questions intelligently.

Day 8: The victim's symptoms became worse. The victim experienced slight breathing distress, some arm weakness, great thirst, and had a fever of $105^{\circ} \mathrm{F}\left(40.5^{\circ} \mathrm{C}\right)$.

Day 9: The victim experienced acute breathing distress, profuse sweating over the entire body, arm incoordination, and ascending numbness. Swallowing became impossible. The victim became semiconscious and died.

\section{Case 2. Exposure in North America (Sulkin and Greve, 1954)}

The victim picked up a grounded bat and was bitten on the forearm. The bat was discarded.

Day 1 of symptoms, 16 days later: The victim experienced aching of the forearms and developed a fever of $103^{\circ} \mathrm{F}$ $\left(39.4^{\circ} \mathrm{C}\right)$.

Day 2: The victim felt generally achy, became nauseated and vomited, and one arm became paralyzed.

Day 7: The victim was unable to swallow and later became semicomatose to comatose.

Day 9: The victim's blood pressure decreased, and the victim died.

\section{Case 3. Exposure in North America (Irons and others, 1957)}

The victim was exposed to airborne rabies in a cave occupied by millions of Brazilian free-tailed bats.

Day 1 of symptoms, about 6 weeks later: The victim had visual problems that precluded driving. The victim reported a night of fitful sleep and nightmares.

Day 2: The victim had convulsive seizures while trying to drink water and the throat muscles became paralyzed. The victim also had breathing difficulties and acute anxiety.

Day 3: Symptoms grew worse, and supportive therapy was ineffectual.

Day 4: The victim died.

\section{Case 4. Exposure in North America (Humphrey and others, 1960)}

The victim picked up an injured silver-haired bat that was being attacked by dogs, placed the bat in a tree, and was bitten on the left forefinger. The victim was given antiserum 3 days later and started on vaccine 4 days after being bitten.

Day 1 of symptoms, 26 days after the bite: The victim's inner left arm became numb to the first two fingers. The victim's abdomen and spine became painful.

Day 8: The symptoms worsened, and numbness extended to the victim's arms. The victim was unable to urinate, then suffered overflow incontinence.

Day 9: The victim had poor limb muscle control and pain in many parts of the body. The victim was able to eat breakfast.

Day 10: The victim had severe leg and abdominal pain yet ate well.

Day 11: Symptoms became worse. The victim could not pass gas but ate well.

Day 12: The victim could not swallow mucus and felt heaviness in the chest. The victim died. 


\section{Case 5. Exposure in North America (Humphrey and others, 1960)}

The victim was awakened by a bat biting his left ear lobe. A cat later ate the bat.

Day 1 of symptoms, 21 days later: The victim felt tingling and pain in the area of the left ear and had pain and tremors that spread to the neck and the left arm.

Days 5 and 6: After further deterioration, the victim had marked tremors in the left arm, prolonged muscle spasms of the legs and neck similar to those seen in cases of tetanus, and hydrophobic spasms when offered water.

Day 7: The victim died.

\section{Case 6. Exposure in Europe (Lumio and others, 1986)}

The victim was bitten by a Daubenton's bat that was acting abnormally. The bat was released.

Day 1 of symptoms, 51 days later: The victim's right palm was numb and felt pain in the neck.

Day 2: The victim's right cheek was numb and painful.

Day 9: The victim was unable to walk and felt generally weak. The victim's right arm and neck were numb, and the chest was painful.

Day 10: The victim developed muscle spasms of the jaw and the legs, prolonged rapid and deep breathing, throat spasms, facial grimacing, disturbed speech, swallowing difficulties, and dilated pupils. The victim exhibited overwhelming fear and was given antirabies serum and sedatives. Symptoms progressed to delirium with shouting, motor hyperexcitability, hypersalivation, and convulsions.

Day 11: The victim died.

\section{Case 7. Exposure in Africa (Meredith and others, 1971)}

The victim was awakened by a bat bite on the lip. The bat was destroyed.

Day 1 of symptoms, about 1 month later: The victim had headache, dizziness, and muscle aches in the neck and back.

Days 2 and 3: The victim sweated continuously and had muscle spasms in the face, arm, and leg. The victim became increasingly confused, irritable, and aggressive, had difficulty sleeping, and had nightmares. The victim's swallowing became progressively more difficult.

Day 4: All of the victim's reflexes became markedly exaggerated. When the victim attempted to drink, tremendous spasms of the mouth and throat muscles prevented swallowing and caused impaired breathing. Despite sedatives, the victim was tense, anxious, sweated profusely, and became increasingly violent and difficult to control. Upon further attempts to drink, the victim cried out in pain and had pharyngeal muscle spasms as well as spasms of the upper torso and arms.

Day 5: The victim went "completely berserk," frothing at the mouth and kicking at attendants, and had to be forcibly restrained. The victim had spontaneous uncontrollable spasms at decreasing intervals until the victim died during a seizure. 


\section{Case 8. Exposure in India (Veeraraghavan, 1955)}

The victim chased boys from a grounded bat that they were pelting with stones. The victim then picked up the bat to place it in a tree, and the bat bit the victim's forearm, from which it was dislodged with great difficulty. The bat was discarded.

Day 1, about 11 weeks later: The victim's symptoms were not recorded.

Day 2 (perhaps later): The victim had severe general sickness, was restless, had difficulty swallowing, and regurgitated fluid that was in the mouth.

Days 3 and 4: The victim's condition deteriorated. The victim became very excited and restless and would shout, but could not explain why.

Day 5: The victim died.

\section{Case 9. Exposure in Australia (Allworth and others, 1996)}

The victim evidently became infected consequent to caring for fruit bats and experiencing a scratch or bite on an unknown date.

Day 1 of symptoms: The victim had pain and numbness in an upper limb.

Day 4: The victim's muscular control became uncoordinated. The victim had difficulty focusing, had shoulder pain, and vomited.

Day 6: After the victim's throat muscles became paralyzed, the victim was unable to swallow and breathe. The victim's condition continued to deteriorate.

Day 11: The victim became comatose.

Day 16: The victim died. 
Back cover photos (D.G. Constantine)

Top: A California leaf-nosed bat departing from a mine tunnel in the Sonoran Desert, California.

Bottom: A diadem leaf-nosed bat, Queensland, Australia. 


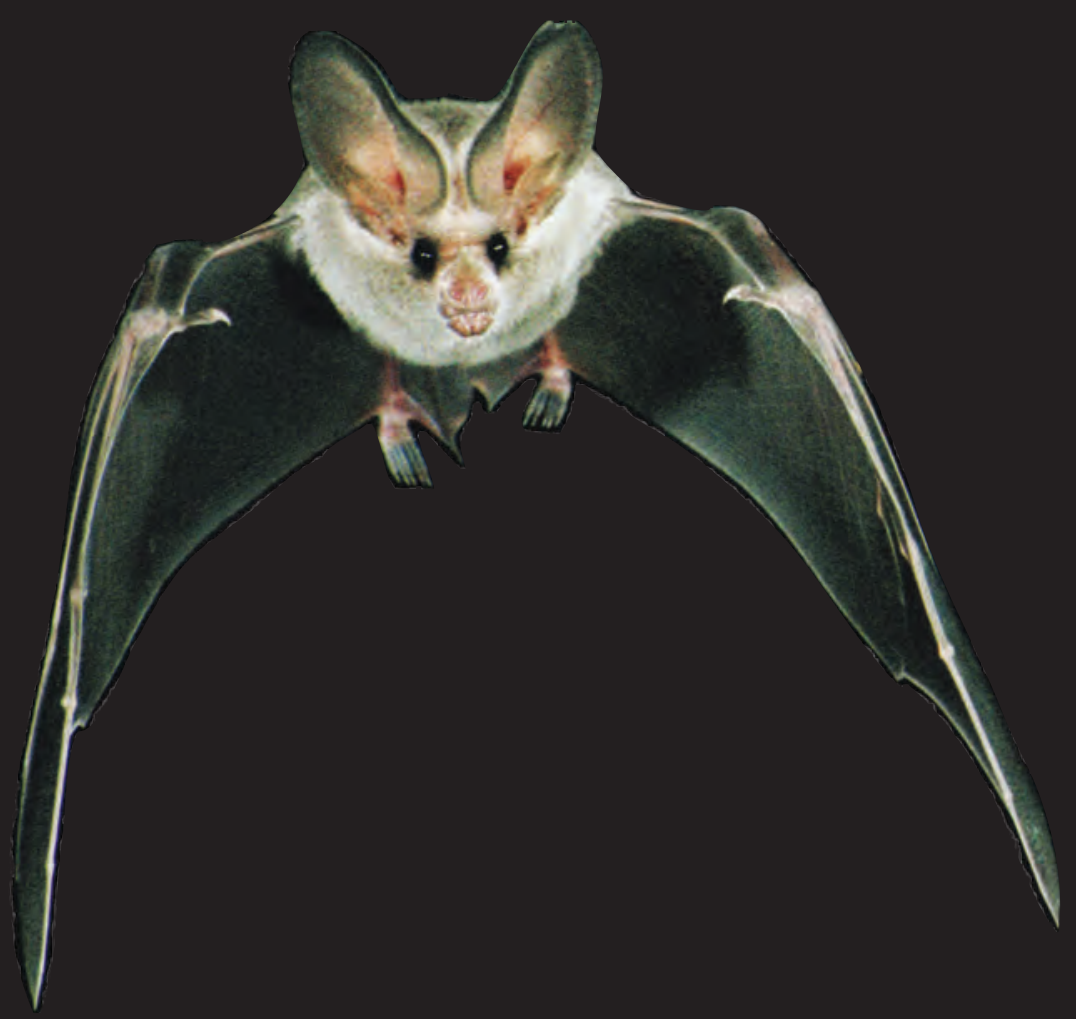

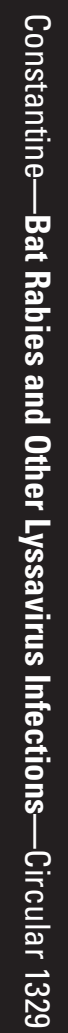

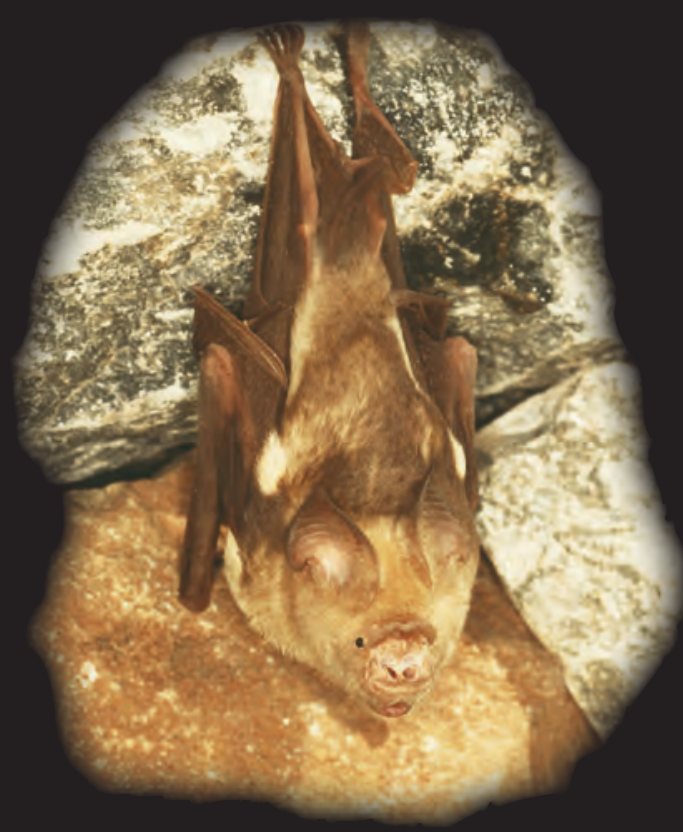

